تصور مقترح لبرنامج تدريبي لمعلمي الدمج فى المدرسة الابتدائية فى في إجئ

\title{
ضوء احتياجاتهم
}

\section{د. هيام عبد الرحيم أحمد على}

المقدمة

شـهد القرن الماضـي تطوراً ملحوظـاً فى مجـال تربيـة الأطفال ذوى

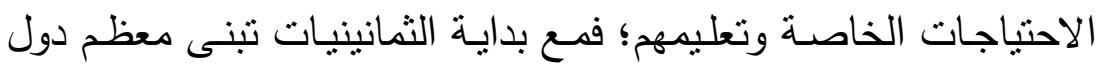

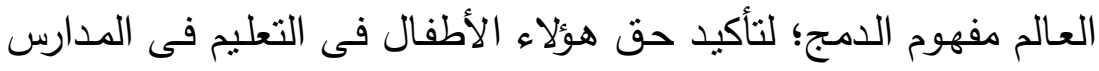
العادية - وفقاً لقدراتهم، وإمكاناتهم - جنباً إلى جنب مع أقراءهم الإنه العاديين

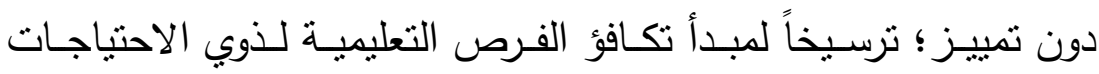

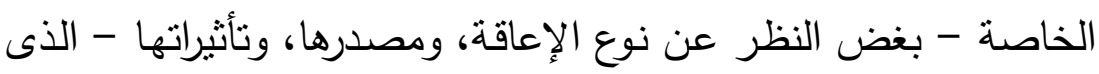

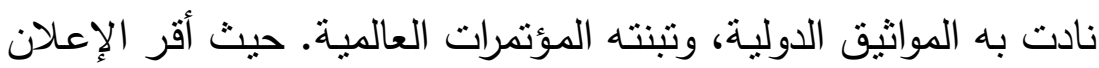

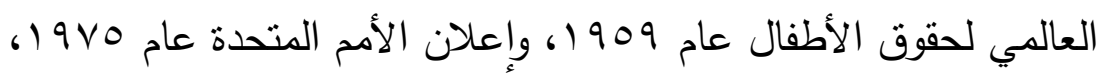
"حقوق الأطفـال ذوي الاحتياجـات الخاصـة في الحصـول علـي التعليم الكناسب، والتمتع بنفس الحقوق المدنية والسياسية التي يتمتع بها غيرهم

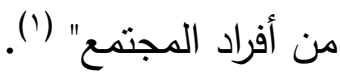

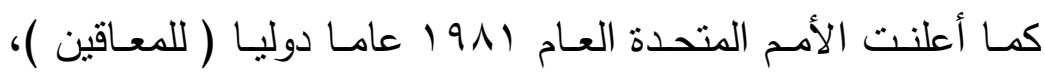
وأقرت - في العام ذاته - ميثاق الحقوق الإنسانية لذوي (الإعاقات )،

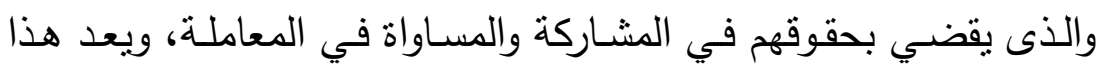

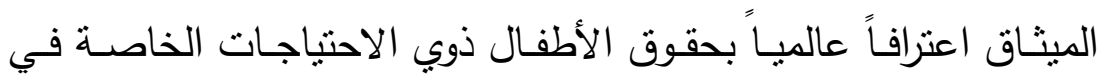

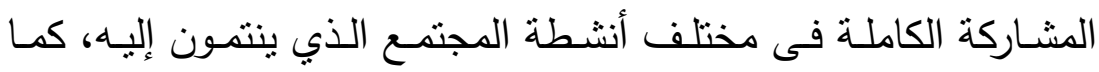
عرفت الفترة ( ب191 - 1994 ) بعقد الأمم المتحدة لذوي الاحتياجات

الخاصة (r). 


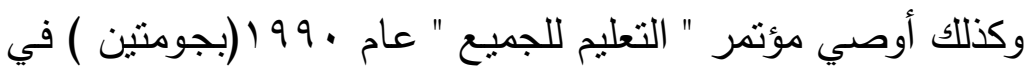
مادته رقم (ب. ب) أنه يجب علي كل دولة اتخاذ كافة الإجراءات اللازمة

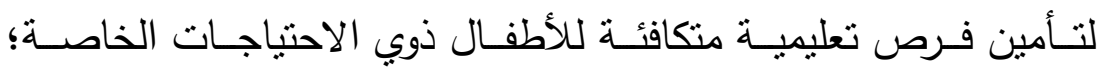

بوصفهم جزءاً من النظام التعليمى (r).

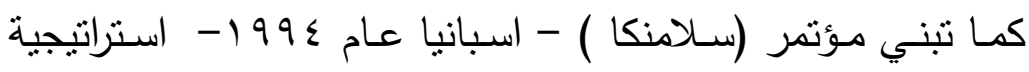
التعليم الدمجي؛ كاستراتيجية لنطوير التعليم للجميع، وأكد حق الأطفال

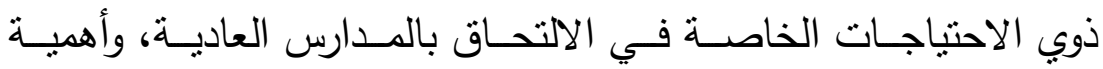

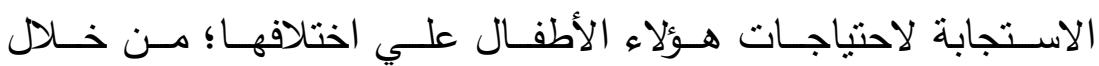

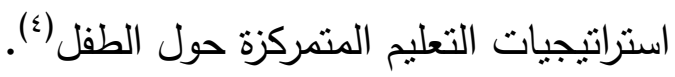
وقد نوجت هذه الجهود بصدور الاتفاقية الدولية لحقوق الأطفال ذوي

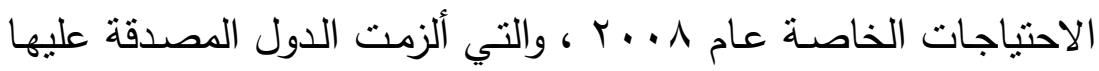
بدمج الأطفال ذوي الاحتياجات الخاصـة دمجاً كلياً في مدارس التعليم • العام وتمشياً مع التوجهات العالمية تعالت الصيحات فى مصر - من قبل

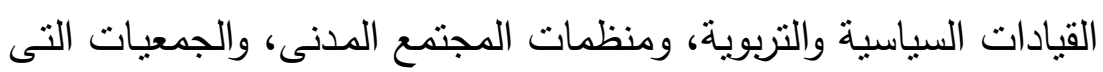

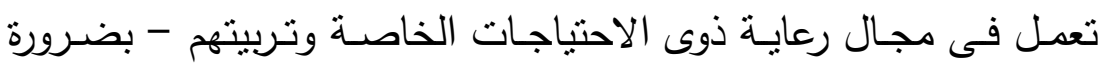

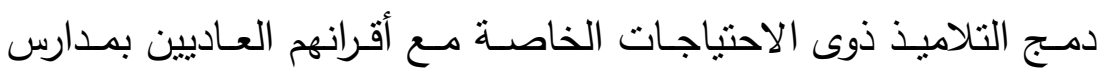

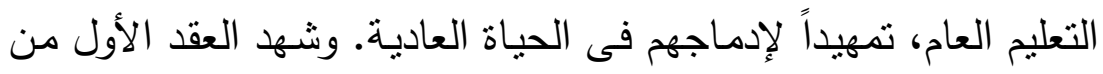

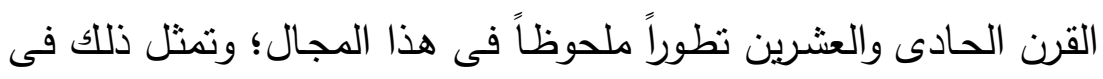

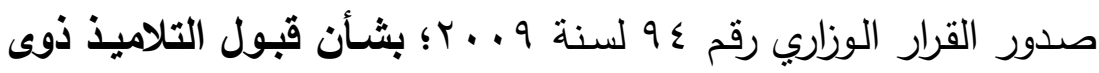

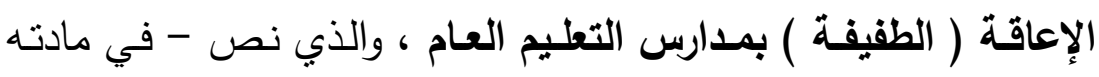
الأولي - علي تطبيق نظام الدمج بالصفوف النظامية بمدارس التعليم العام، ومؤسسات رياض الأطفال (०). 
ومع تزايد الاتجاه نحو تعليم الأطفال ذوى الاحتياجات الخاصـة فى

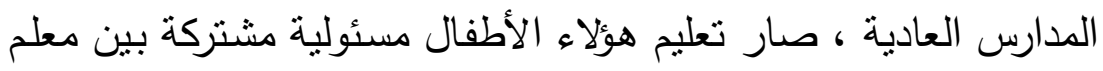

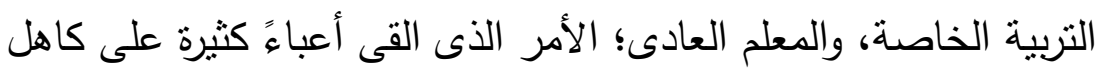

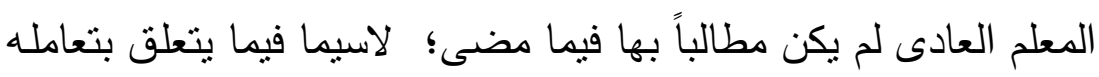

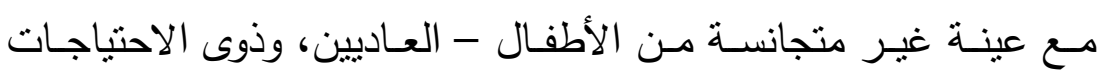

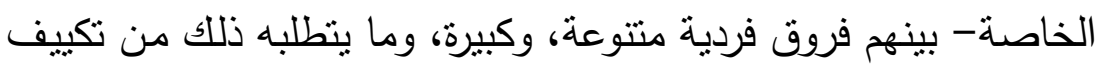

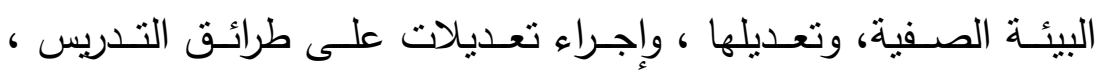

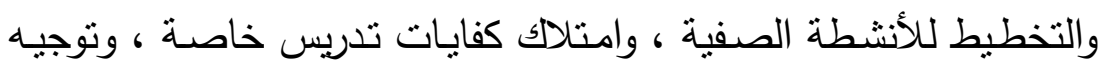

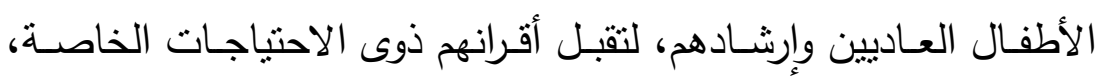

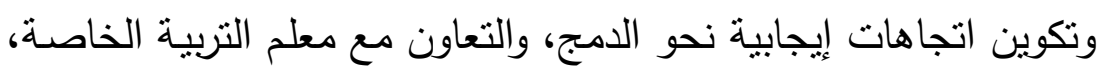

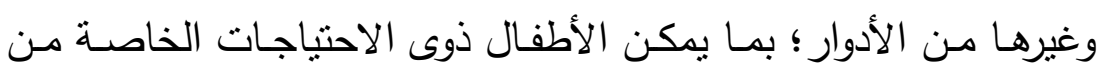

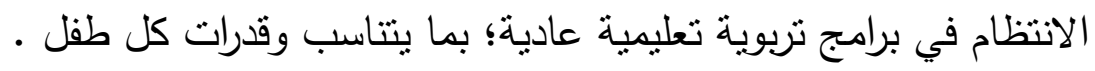

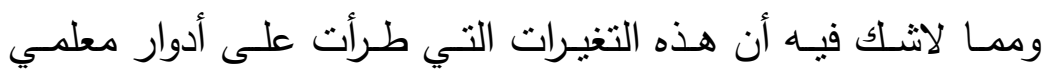

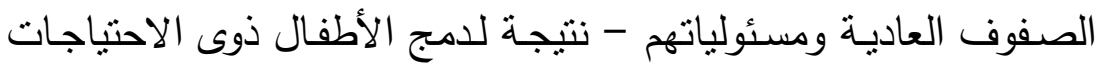

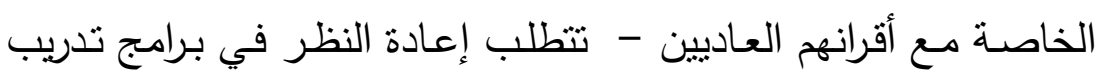
هؤلاء المعلمين؛ لتطوير إمكاناتهم، وقدراتهم؛ بما بلائم منطلبات عملية

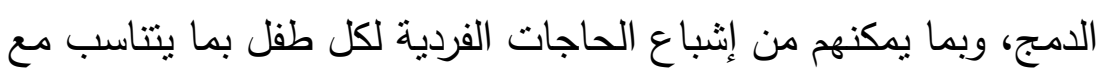

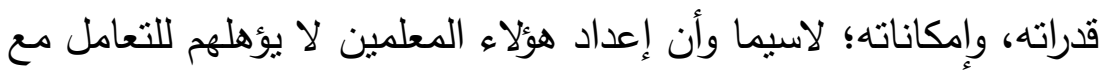

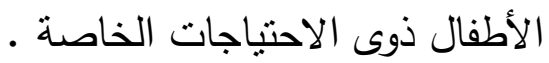

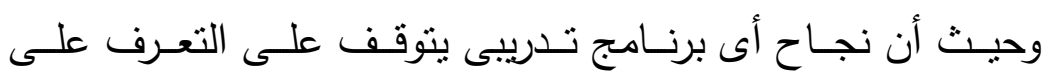

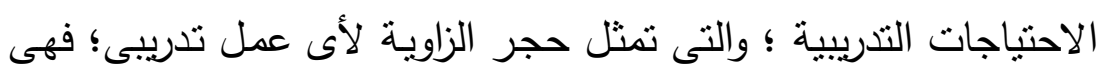
البدايـة الحقيقية فى سلسلة الحلقات التى تكون العملية التدريبية، وأحد المدخلات الأساسية التى تضمن تحديد أهداف واضحة ومحددة للتدريب، لبلهيه والموارد اللازمة للبرامج التدريبية وتتفيذها. 
وعليـه يستدعى ذلك تحديد الاحتياجـات التدريبيـة اللازمـة للمعلمين العاملين بصفوف الدمج بمدارس التعليم الابتدائي، ووضع تصور مقترح؛

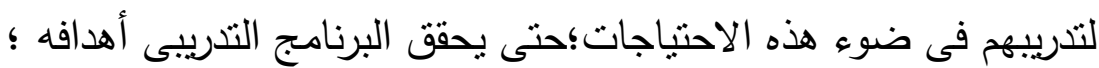
ولا يكون التدريب مضيعة للوقت، والجهد، والمال. مشكلة الدراسة تمثل عملية دمج الأطفال ذوى الاحتياجات الخاصـة بمدارس التعليم

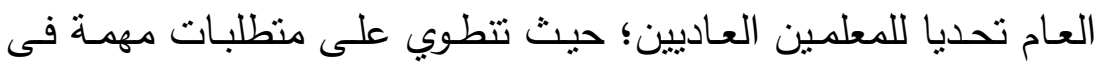
أدوارهـم ، وكفايـاتهم التعليميـة ، واتجاهـاتهم ، وممارســاتهم التدريسـية

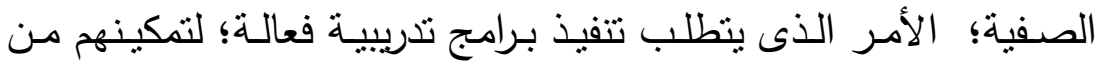

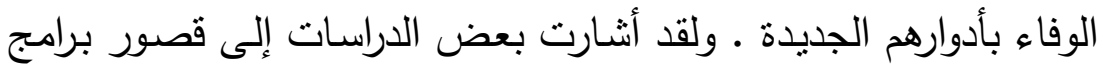
تدريب هؤلاء المعلمين، وندرتها؛ مما تسبب فى ضعف قدرتهم علي فهم

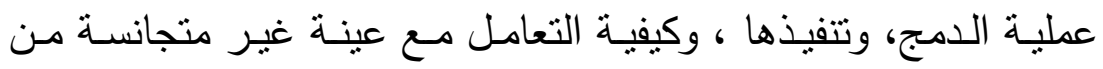

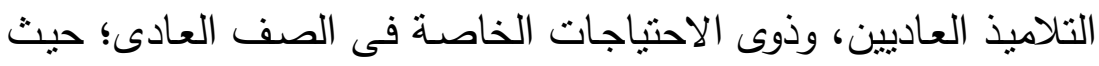

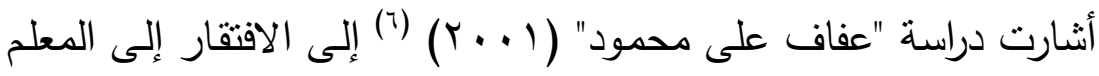
القادر على التعامل مع التلاميذ العاديين، وذوى الاحتياجات الخاصة فى التى الوقت نفسه؛ ويرجع ذللك إلى نقص التدريبات؛ حيث لم يحصل المعلمون الذين يعملون بصفوف الدمج إلا على قليل من الدورات التدريبية .

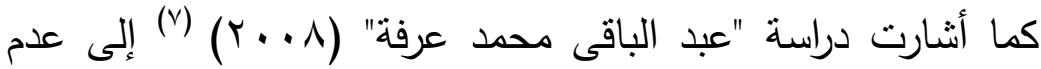
قناعة معلمى صفوف الدمج بالدورات التى يحصلون عليها من ناحية ، التهاهية

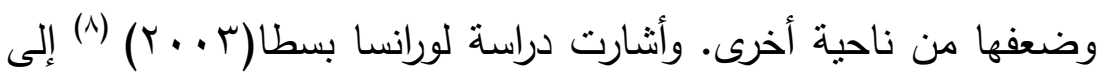
قلة التدريب الذى قدم للمعلمين فى مدارس الدمج ، وضعف تلاك

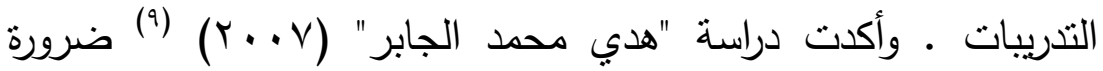
إعداد دورات تدريبية؛ لتزويد المعلمين بالمعلومات، والمهارات، والكفايات التي تساعدهم فى العمل مع التلاميذ ذوي الاحتياجات الخاصة. 
الأمر الذى يثبر إلى الحاجـة الماسـة إلى الاهتمام ببرامج التدريب

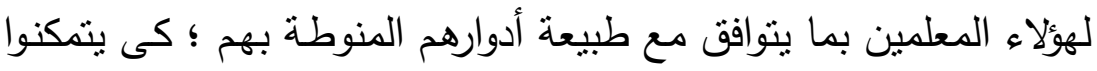

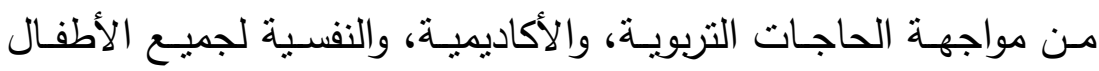
بفئاتهم المختلفة ـ فضلاً عن تطوير اتجاهاتهم إيجابياً نحو عملية الدمج. ولكي تحقق بـرامج التـدريب الهـف منهـا ، ينبغس التعرف على آراء

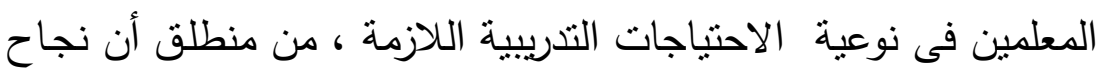
أى برنامج تدريبى يقاس بمدى مراعاته الاحتباجات التدريبية للفئة المعنية بالعملية التدريبية.

\section{وعليه يمكن صياغة مشكلة الدراسة الحالية في التساؤلات التالية}

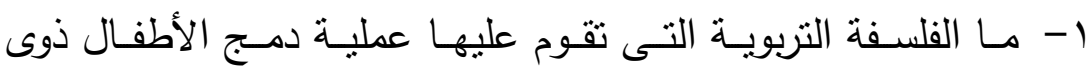

$$
\text { الاحتياجات الخاصة فى مدارس التعليم العام؟ }
$$

r- ما المتطلبات اللازمة لنجاح أسلوب دمج الأطفال ذوى الاحتياجات

$$
\text { الخاصة فى مدارس التعليم العام؟ ماج }
$$

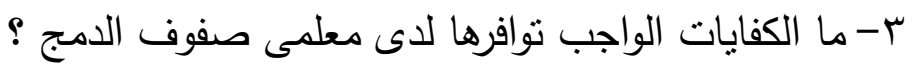

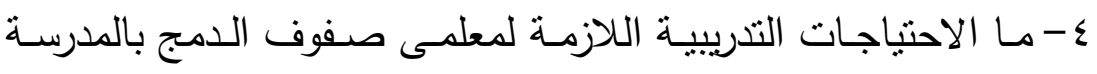

$$
\text { الابتدائية ؟ }
$$

0- مـا التصـور المقترح لبرنـامج تـدريبى لمعلمى الـمـج فـى المـدارس

$$
\text { الابتدائية ، فى ضوء احتباجاتهر ؟ }
$$

\section{أهمية الدراسة}

\section{تتضح أهمية الاراسة الحالية فيما يلى :}

- - نجاح برامج الدمج للأطفال ذوى الاحتياجات الخاصة يعتمد بشكل رئيس على نوعية المعلم القائم على ثلك العملية .

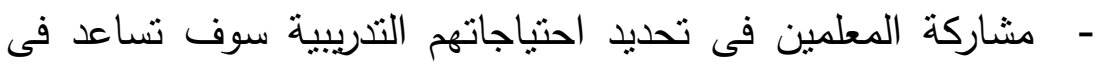
معرفة اتجاهاتهم، ورغباتهم، كما تساعد فى وجود نوع من الاتصال 
المباشر، والفعال بينهم وبين القائمين على التدريب؛ الأمر الذى يساعد فى القضاء على عديد من السلبيات التى قد تبرز فى حالة عدم توافر هذا الاتصال. - وضع تصور مقترح لتدريب معلمى الامج فى المدارس الابتدائية، فى في

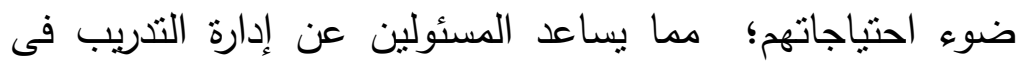

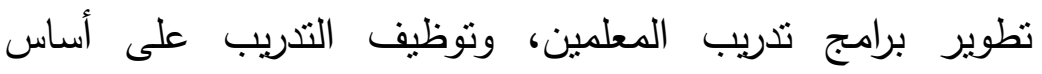
احتياجاتهم الفعلية. أهداف الدراسة

تسعى الدراسة إلى تحقيق عدد من الأهداف؛ لعل من أهمها : التها

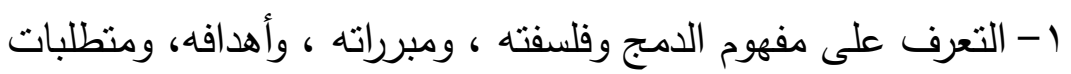

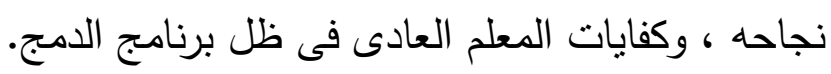

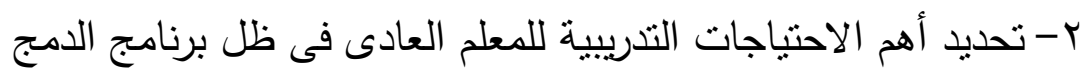
بمدارس التعليم العام. r-وضع تصور مقترح لبرنامج تدريبي للمعلم العادى فى صفوف الدمج بالمدارس الابتدائية، فى ضوء احتياجاته التدربيية . حدود الدراسة بالمداس - - الحد البشرى : المعلمين القائمين على التدريس فى صفوف الدمج •

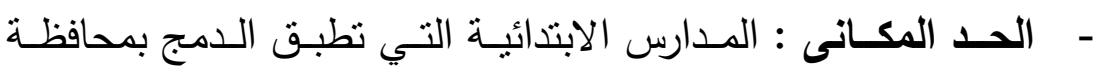
الإسكندرية على مستوى الإدارات التعليمية الثمانية.

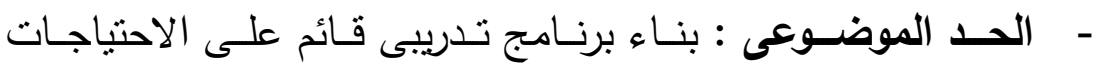
التدريبية للمعلمين. 
الامج : يقصد به أن يتاح للتناميذ ذوى الاحتياجات الخاصة أماكن فى

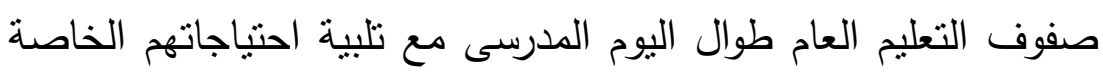
داخل الصف؛ لزيادة فرص تعلمهم (·).

معلمو الدمج : ويقصد بهم: المعلمون العاديون الذين يُدرِّسون للتلاميذ

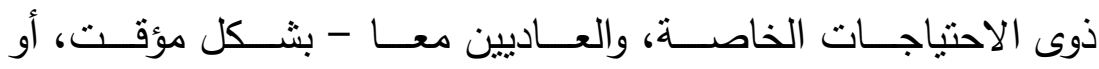
دائم - ضمن البرنامج الدراسي فى بيئة الصف العادية.

الاحتياجات التدريبية : مجموع التغيرات المطلوب إحداثها فى معلومات

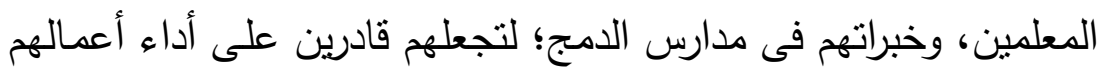

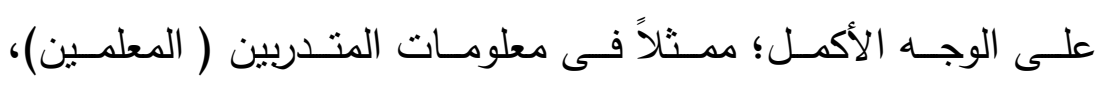

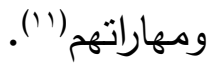

\section{منهج الدراسة ، و و إجراء|تها}

اقتضت طبيعة مشكلة الدراسة الحالية استخدام المنهج الوصفي؛ من

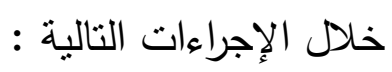

تحليل الأدبيات للتعرف على مفهوم الدمج، وفلسفته ، ومبرراته ، والكفايات اللازمة للمعلم العادى فى ظل برنامج الدمج. تحليل الأدبيات، للتعرف علي مفهوم الاحتياجات التنريبية ، وأهدافها ، وأهميتها ، وأساليبها.

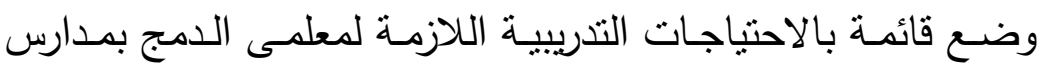
التعليم العام ، وعرضها علي مجموعة من الخبراء ، والمتخصصين بلهي

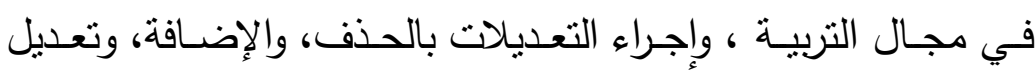
الصياغة؛ للخروج بالاسنبانة في صورتها النهائية . 
تطبيق الأداة علي عينـة عشوائية من المعلمين بالمدارس الابتدائيـة

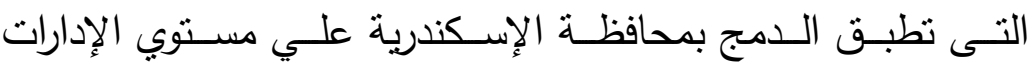

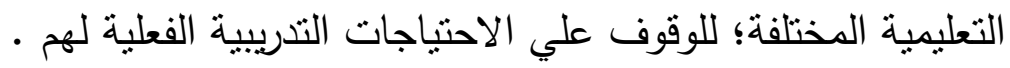
تحليل نتائج الدراسة الميدانية. التوصل في ضوء الإجراءات السابقة، ونتائج الدراسـة الميدانية، إلي

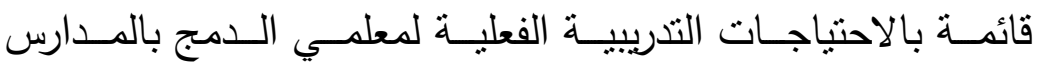
الابتدائية. وضـع تصور لبرنامج تدريبى لمعلمى الدمج فى المدارس الابتدائية؛

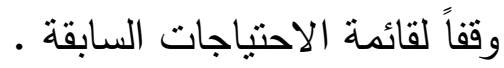
الإطار النظرى للاراسة أولاًا : الامج أ- مفهوم الامجج : الامج

بـدأ مفهوم الـمـ Inclusion في الظهـور مـع بدايـة التسـعينيات

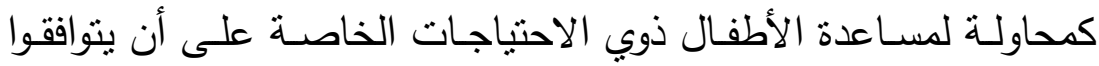

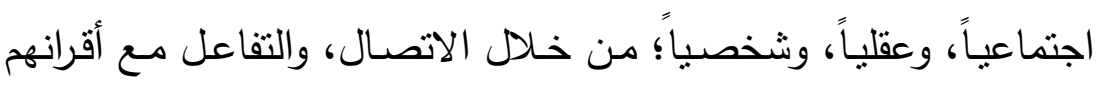
العاديين.

وقد تعددت وجهات النظـر بشـأن مفهوم الــمج؛ حيث نظر إليـه البعض علي أنه توفير فرص التعلم القائمة علي المساواة للأطفال ذوي لوني الإعاقة البسيطة؛ من خلال إلحاقهم بالبيئة التربوية الأكثر ملاءمة، وقدرة علي تلبية حاجاتهم. وفي كثير من الحالات تتمنل هذه البيئة في الصف

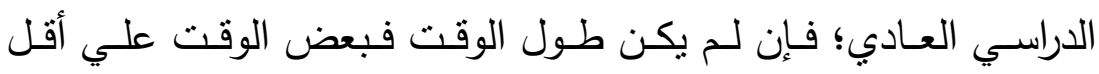
تقدير (r) - (I)

بينما عرفه آخرون بأنه : وضـع الأطفال ذوبي الاحتياجات الخاصـة

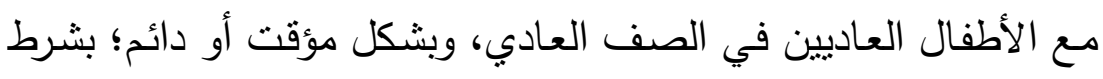


تقديم خدمات التربية الخاصـة، والخدمات المساندة لهم، وإعدادهم للعمل في المجتمع مع العاديين (rا'). وهناك من رأى أن الدمج منهج تربوى واجتماعى تقوم بـه المدارس؛

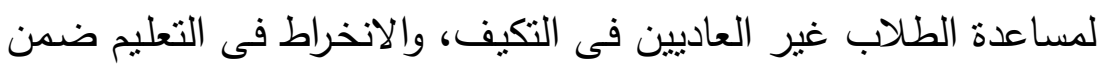
البيئة التعليمية التقليدية، ثم فى المجتمع الكبير مستقبلاً (ء) (1).

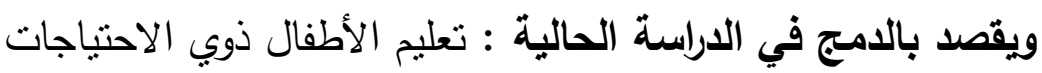

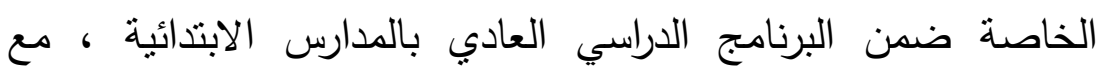
تزويدهم بالخدمات التي تتيح لهم كل ظروف الحياة الطبيعية و التعليمية المتاحة لأقرانهم العاديين.

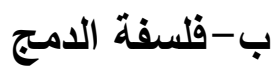
تتهض فلسفة دمج الأطفال ذوى الاحتياجات الخاصة مع أقرانهم العاديين بمدارس التعليم العام؛ على عدد من الأسس التى تمثل مبررات

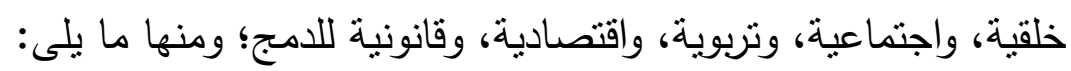

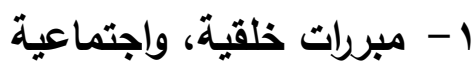
منلت الجوانب الخلقية، والاجتماعية التي تدعو إلى اتجاهات إيجابية

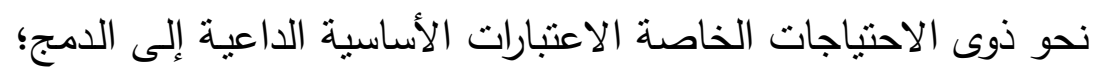
فقد علت نداءات العدالة، وحقوق الإنسان بسلبية عزل ذوى الاحتباجات الخاصة؛ من خلال المدارس الداخلية التي نؤثز فى نفسية هؤلاء الأطفال

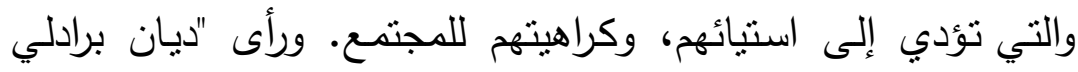
وآخرون" أن في الدمج للتلاميذ المعوقين ما يجعلهم يتلقون تربية نوعية، وحراهي

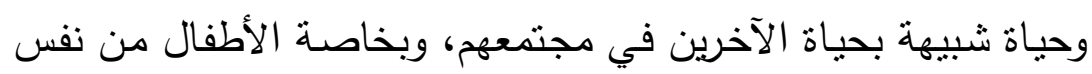

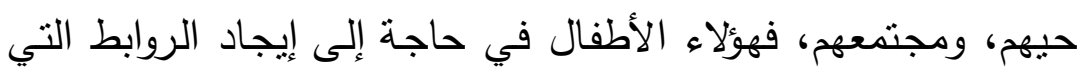

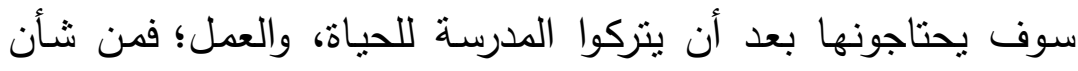

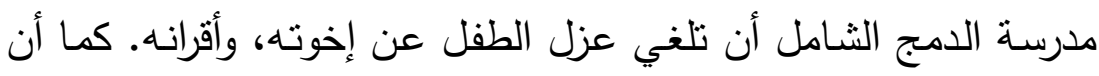
انتقال الطالب إلى مدرسة مختلفة ( مدرسة التربية الخاصـة ) له مؤشر إنش 
واضـح على أن الطفل ليس بمستوى التوقعات؛وهذا من شأنه أن يفقده تقديره لذاتههويعوق تحصيله (10). r- مبررات تريوية أو تعليمية

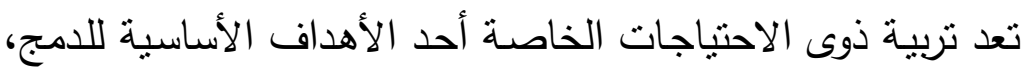

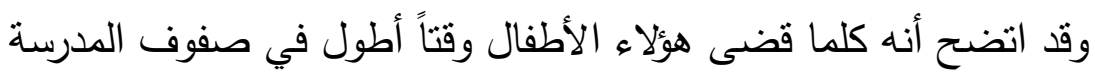

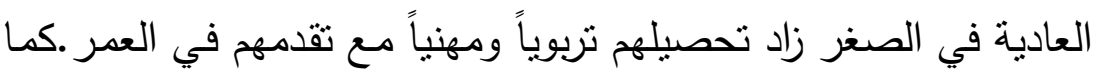

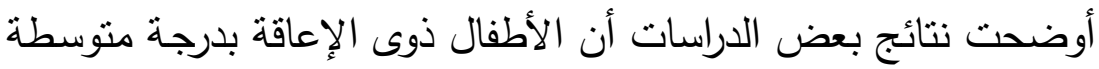

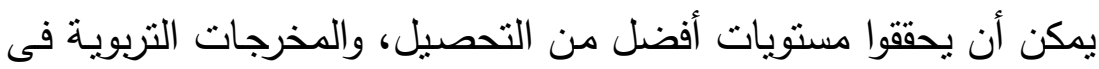
الوضع التربوى العام (1') - (1). r- مبررات (قتصادية تعد قضية تمويل التعليم من القضايا المهمة التي نتشل بال القائمين

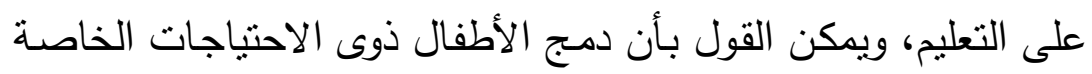
في المدارس العادية يمكن أن يحقق من الناحية الاقتصادية نوفير :

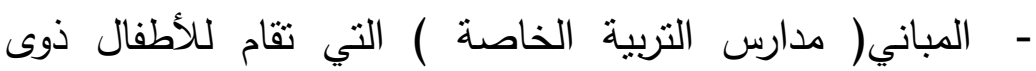
الاحتباجات الخاصة بفئاتهم المختلفة. - ما ينفق من رواتب الإداريين والعاملين بمدارس التربية الخاصة. - أعداد المعلمين بمدارس التربية الخاصة. - الإدارات والأقسام الخاصة بالتربية الخاصة. ؛ - مبررات قانونية يخلق عزل الأطفال ذوى الاحتباجات الخاصة في مدارس خاصـة

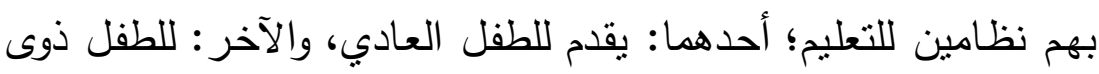

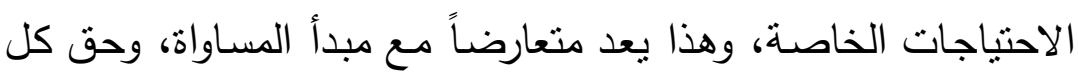
طفل في نيل حقوقه، وحصوله على حق التعليم. في حين تسعى سياسة

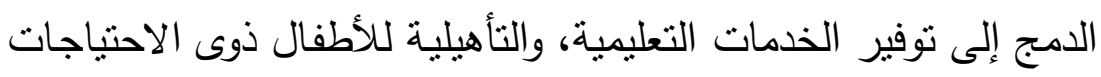


الخاصة بصورة مناسبة، ومتوازنة مع ما يحصل عليه الأطفال العاديون

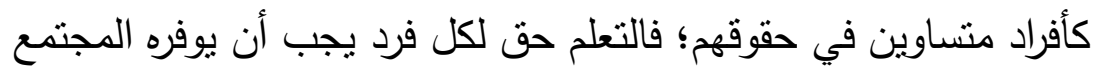
بغض النظر عن طبيعة المشكلات التي يعانيها الفرد. (v)

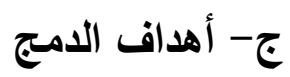
يهدف دمـج الأطفال ذوى الاحتياجات الخاصـة مـع أقرانهم العـاديين فى مدارس التعليم العام إلى عدد من الأهداف، تتمنل فى : • أهداف تعليمية : تتضمن توفير بيئة تعليمية تتيح لذوبي الاحتياجات

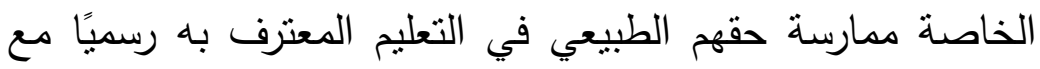
أقرانهم العاديين؛ بما يتتاسب مع قدراتهم، وخصائصهم. أهداف اجتماعية : تتضح في تيسير عملية التطبيع الاجتماعي بين

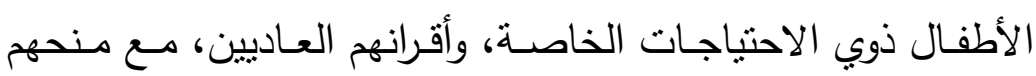
فرص المساواة، وتيسير كافة الخدمات لهم؛ بما يُسهم في بناء الفرد الفياج

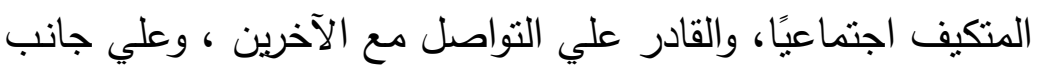
آخر تكوين اتجاهات إيجابية لدي الأطفال العاديين تجاه أقرانهم من وعن الهن

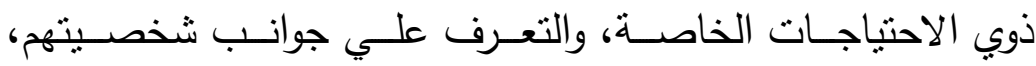
واستعداداتهم للتعليم.

أهداف نفسية : تكمن في تتمية شعور الأطفال ذوي الاحتياجات الخاصة بالأمن، والطمأنينة فى التعامل مع الآخرين، والثقة بالذات؛ من خلا التعليم، والمشاركة في الأنشطة المختلفة، والحياة جنباً إلى الى العين

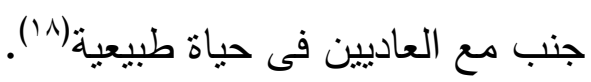
د - متطلبات دمج ذوى الاحتياجات الخاصة فى مدارس التعليم العام

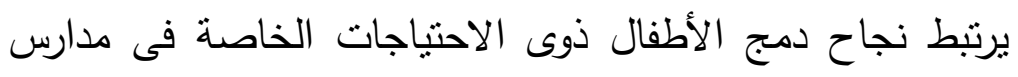
التعليم العام بتوافر مجموعة من المرتكزات؛ منها: 
1-تحديد الاحتياجات التعليمية للتلاميذ : تتطلب عملية الدمج التعرف

على الاحتياجات التعليمية للتلاميذ العاديين عامة، وذوى الاحتياجات

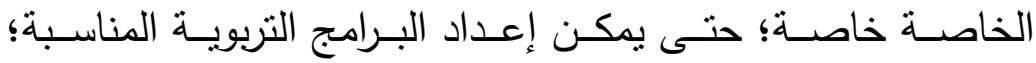

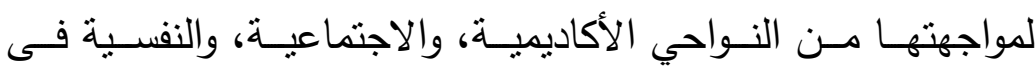
الصفوف العادية .

ץ-تهيئة القائمين على التربيـة لعملية الامج : يجب تغيير اتجاهات

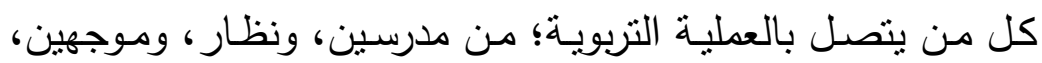
وتهيئتهم لفهم الغرض من الدمج، وتعريفهم باللوائح، والقوانين، والنظم

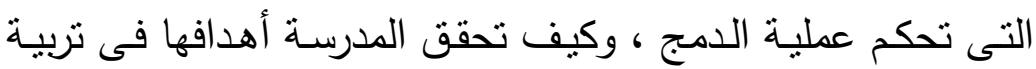

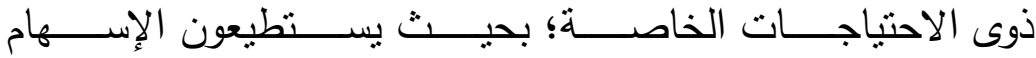

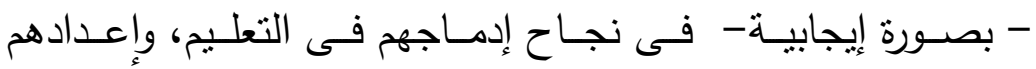
لبلاندماج فى المجتمع.

r- إعداد المعلمين لعملية الدمج : قبل تتفيذ أى برنامج للامج ، يجب اعدي

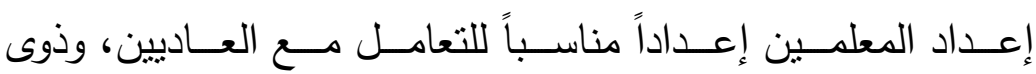
الاحتياجات الخاصة معا ، ومعرفة كيفية إجراء ما يلزم من تعديلات فى طرائق التدريس؛ لمواجهة الحاجات الخاصـة بذوى الاحتياجات

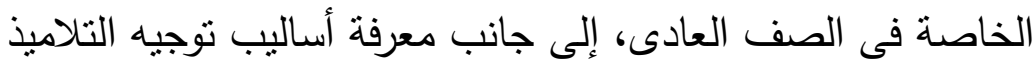
العاديين،وإرشـادهم؛ بما يساعدهم فى نقبل أقرانهم ذوى الاحتياجات

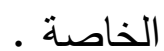
ع- إعـاد المنـاهج، والبـرامج التريويـة : يتطلب الدمج ضـرورة إعداد

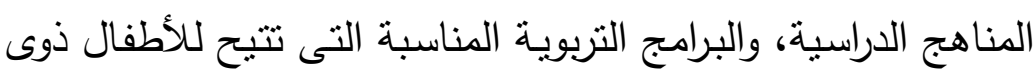

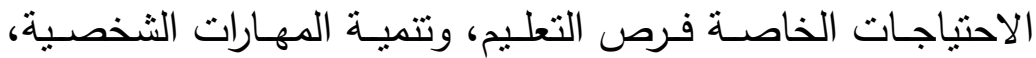

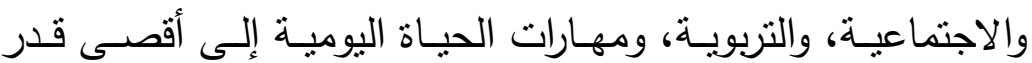


تؤهلهم لـه إمكاناتهم، وقدراتهم، وبمـا بسـاعدهم فى التعليم، والتوافق الاجتماعى داخل المدرسة، وخارجها.

0- تـوفير بيئسة مدرسية معـدة بمسـلزمات مكانيـة، وتجهيزيـة؛ بمـا

يتتاسب مع إمكانات الأطفال ذوى الاحتباجات الخاصة، وقدراتهم.

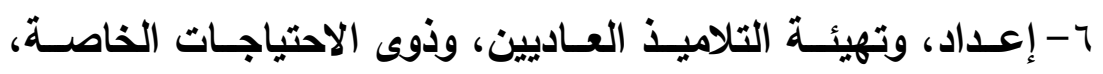
وأسـرهم؛ لتقبل عمليـة الدمج والتعرف على التغيرات، والمسئوليات

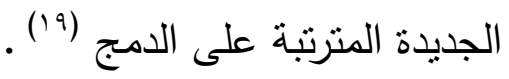

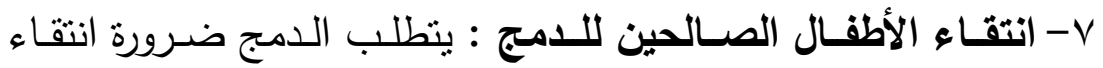
الأطفال ذوى الاحتياجات الخاصة الصالحة للامج وفق أسس تربوية

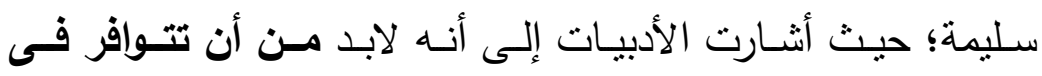

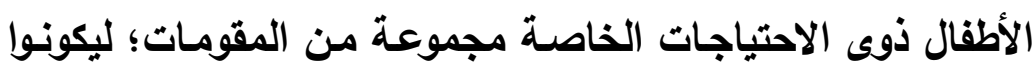
مؤهلين للامج مع أقرانهم العاديين فى الصف العادى؛ ومنها أن :

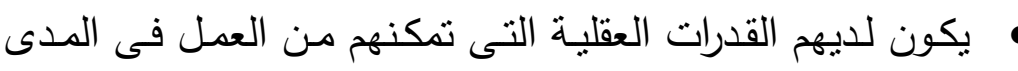
المعرفى الموجود فى الصف إلى حد ما.

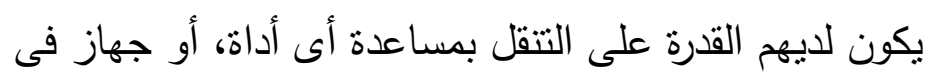

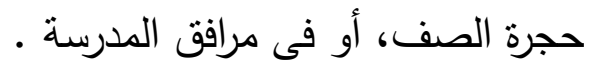

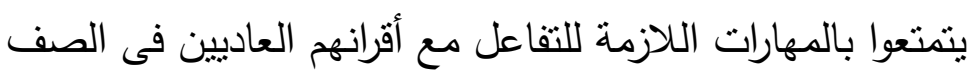
العادى، وفى الأنشطة الترويحية، والاجتماعية .

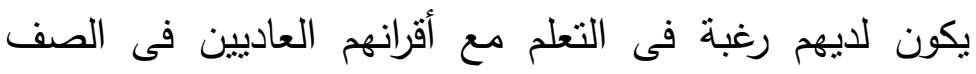
العادى. يكون قد نوافرت لديهم خبرات فى أنشطة مدمجة، سواء أكان

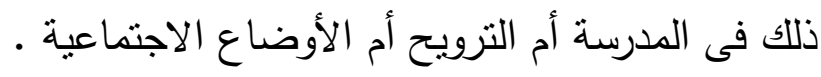

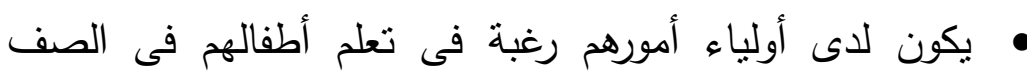
العادى. 
• يكون لديهم القدرة على الاعتماد على النفس فى تأدية معظم المهارات؛ كالعناية بالذات، والأنشطة الحياتية اليومية. يتمتعوا بالاستقرار العاطفى الـلازم للتكيف مـع متطلبـات البيئة

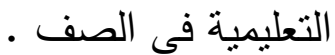
يكون لديهم القدرة على التعبير عن حاجاتهم بالكلام، أو الكتابة،

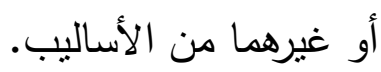

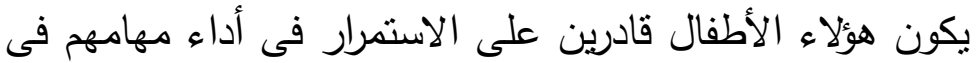
الصف العادى دون الاعتماد كثيراً على التغذية الراجعة، والانتباه من قبل المعلم؛ كما هو متوافر لهم فى الصفوف الخاصة (r.r) هـ - كفايات المعلم فحى مدرسة الامج يؤدى معلم الصف العادي دورًا بالغ الأهمية في إنجاح برامج دمـج

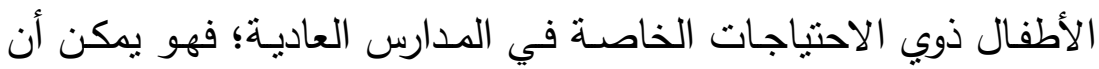
يسهم في تكوين قاعدة بيانات مناسبة حولهم، ويشارك في تصميم البرامج

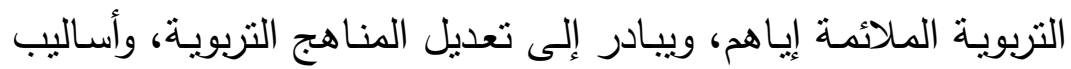

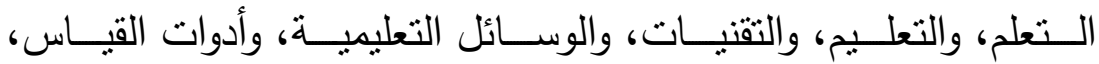
والاختبارات، بما بنسجم مع احتباجاتهم. ولكى يتمكن من أداء ذلك لابل

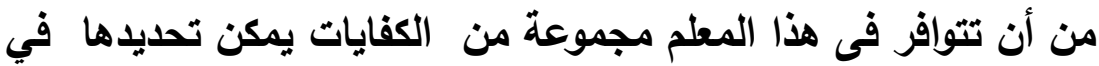

1 - تنمية اتجاهات إيجابية نحو التلاميذ ذوى الاحتياجات الخاصـة:

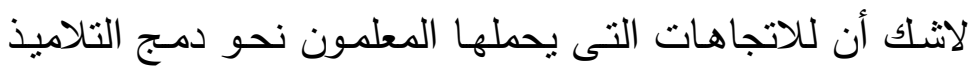

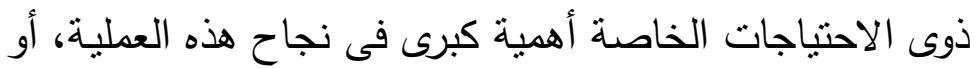

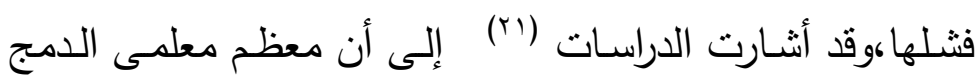

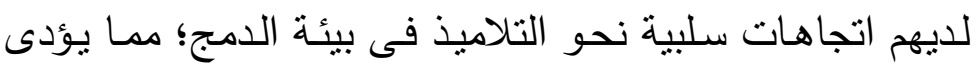

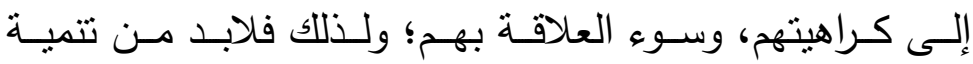


اتجاهات إيجابية نحو هؤلاء التلاميذ. كما أنه كلما كانت اتجاهات المعلمين نحو الدمج ايجابية أدى ذلك إلى التزامهر بدورهم المنوط بهم حيال هذه الفئة من الأطفال؛ مما يؤدي بهم إلى بذل جهد فائق؛ لتوفير سبل الرعاية التي من شأنها أن تمد التهد

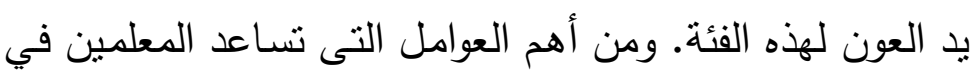

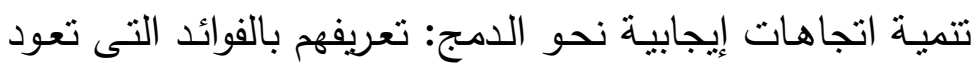
عليهح من ورائه ، والتى منها:

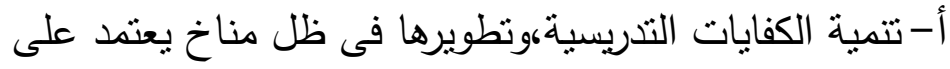

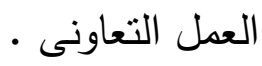
ب- ت تمية مهارات التخطيط الجماعى للخطط التعليمية . ج-نبادل الخبرات بينهم، وبين بقية أعضاء فريق المساندة (rr). r- المشاركة فى تصنيف حالات الأطفال ذوى الاحتياجات الخاصة؛ وهذا يتطلب منه الإلمام بالمعارف المختلفة حول ذوى الاحتياجات

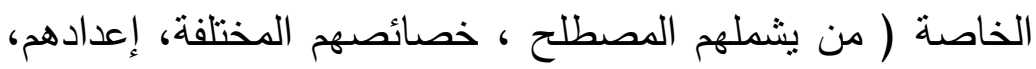

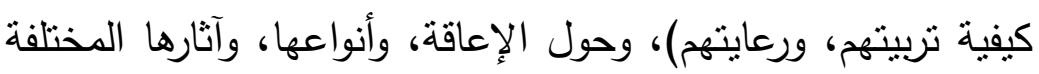
النفسية والاجتماعية على الفرد، والإلمام بخصائص الفئات القابلة •للدمج

r- تطويع الأهداف التعليمية: لمواجهة الحاجات الفردية لكل تلميذ، ولتلبية القدرات الخاصة للتلاميذ ذوى الاحتياجات الخاصة؛ من لاهن

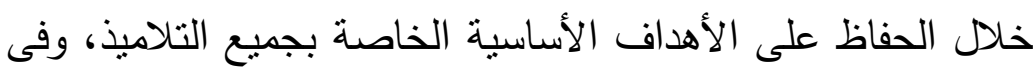

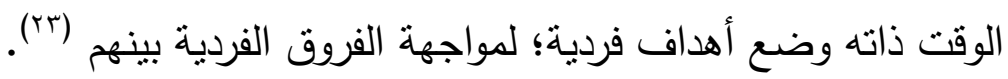
ع - تكيـف المنــاهج : لكي تـتلاءم مـع أنمـاط الاحتياجـات التربويـة

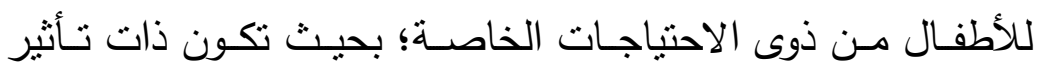
إيجابى أكاديمياً، واجتماعياً، عليهم وعلى أقرانهم العاديين: وذلك في لإني 
ضوء نتائج قياس مستوى أدائهم الحالي؛ من حيث جوانب القوة والضعف لديهم. فالمعلم هو المسئول عن اقتراح التغييرات اللازمة؛؛

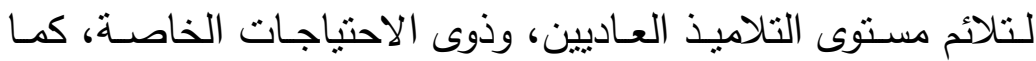
يجب عليـه تحقيق مبدأ (وظيفيـة المنهج)؛ أى ربطـه بمـا يشـاهده، ويمارسه، ويواجهه التلميذ فى البيئة من حوله.

ه- التنويع فى استخدام أساليب التدريس : لمواجهة الحاجات المتباينة لتلاميذ الصف الواحد: وهذا يتطلب - بالضرورة - إعادة تقييم أساليب التدريس، والتعرف على أفضل الأساليب التى نساعد فى تيسير العملية

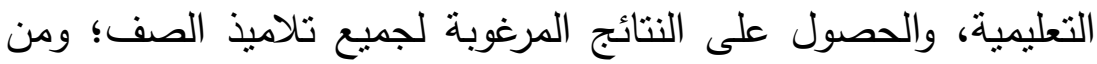

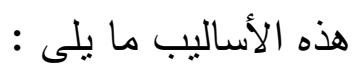

طريقة التعلم التعاونى : هى طريقة تعتمد على التعاون المتبادل

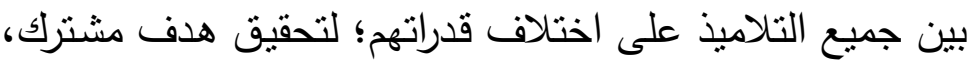

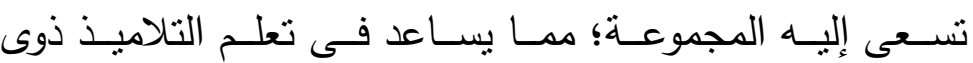

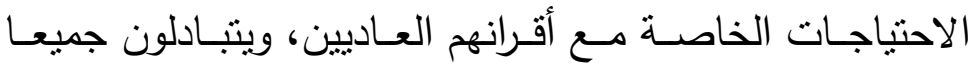
الخبرات؛ لتحقيق أهداف مشتركة فى ظل وجود علاقات إيجابية

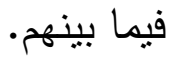
طريقة تدريس الأقران : هى طريقة تعتمد على مساعدة التلاميذ

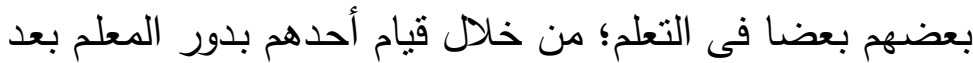

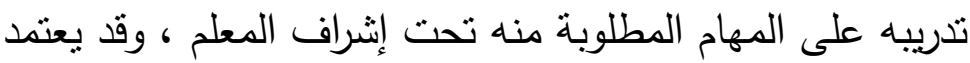

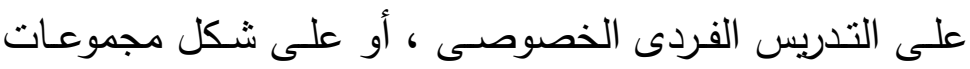

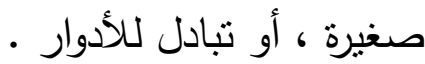

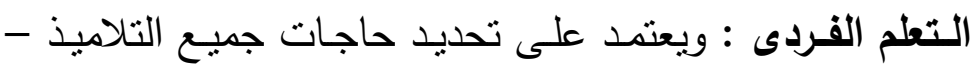

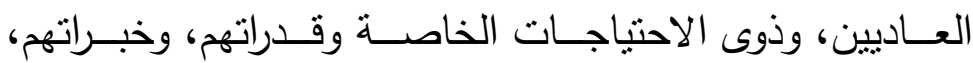

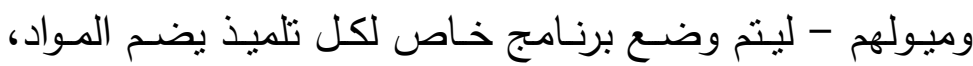


والأنشطة التعليميـة، وأسـاليب التقويم التى نسـاعد فى حدوث عملية التعلم فى ظل وجود تتسيق بين المعلم، والأسرة . التدريس بـالفريق: ويعتمد على اشتراك المعلم العادى، ومعلم

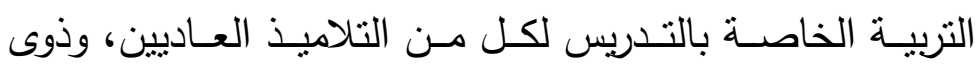
الاحتياجات الخاصة فى نفس زمن الحصة مع وجود تتسيق فيما

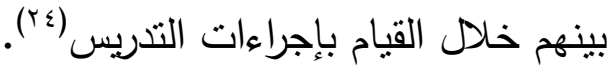

צ- الإلمـام بالمهـارات التى يتطلبها تـريس الأطفـال العـاديين، وذوى الاحتياجـات الخاصـة معسا، ومنها:مهارات الاتصـال الفعـال، وإدارة التتوع، والاختلاف، وتغيير الاتجاهات.

V - تهيئة التلاميذ العاديين لبرنـامج اللدمج التربـوى : إذا كان الدمج

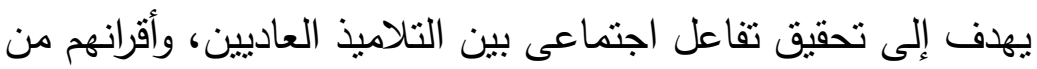

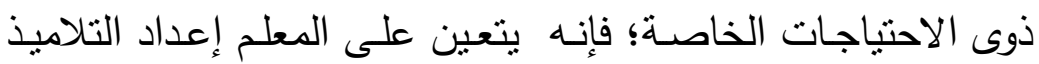

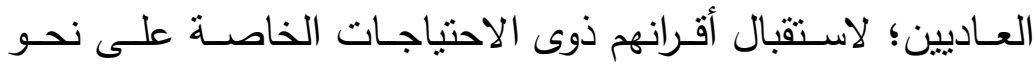

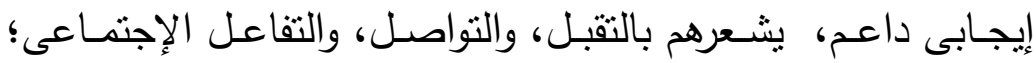

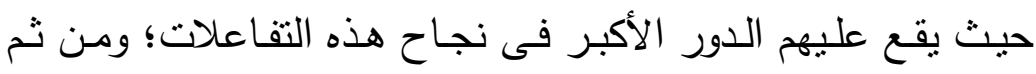

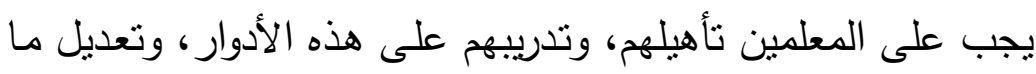

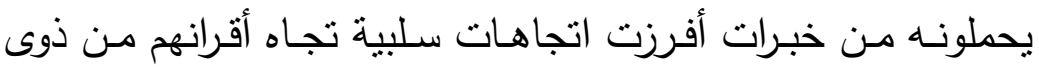

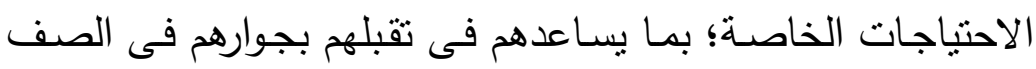

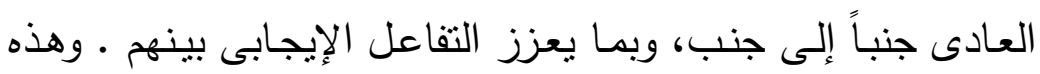

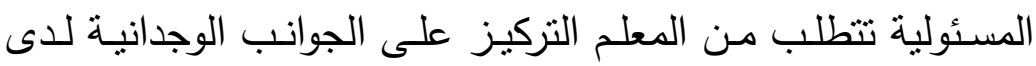
التلاميذ العاديين؛ لتقبل فكرة وجود تلميذ ذوى احتياجات خاصة بينهم داخل الصف، وعليه تعريفهم بطبيعـة الإعاقة، وأسبابها ، وطرائق الاتصـال المناسبة إياهم وفقاً لدرجة الإعاقة، على أن يتم ذلك قبل إنل

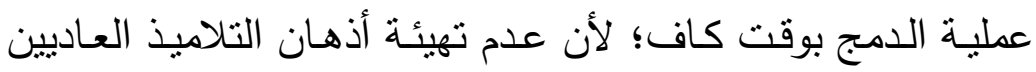


لعملية الدمج قد تأتى بنتائج عكسية، ووخيمة؛ مما قد يؤدى إلى فنل

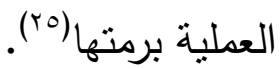

1 - تهيئة التلاميذ ذوى الاحتياجات الخاصة : يجب على المعلم تدريب هؤلاء التلاميذ على مهارات الاستماع الجيد، والتذكر ، والاستقلالية فى العمل ، والمهارات اللغوية، والاجتماعية، والسلوكية . 9- إدارة الصف والتعامل مـع أنماط السلوك غير الملائم : يتطلب من المعلمين فى صفوف الدمج إدارة، وتوجيه الأنماط السلوكية المتباينة

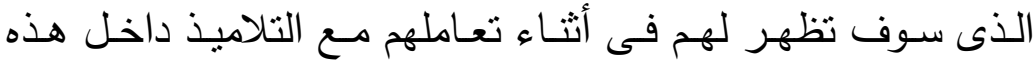
الصـفوف، وتفهم مـا يصـدر عـن ذوى الاحتياجـات الخاصـة مـن

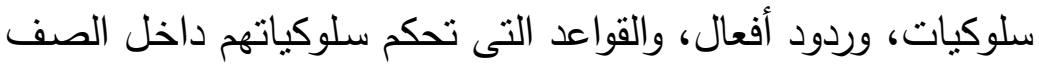

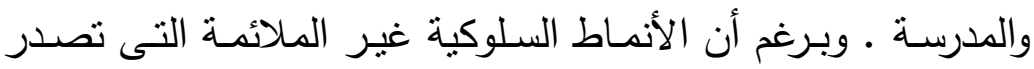

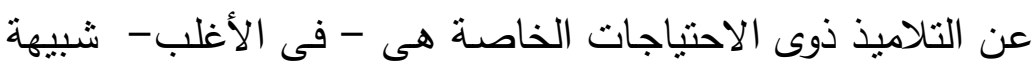
بما يصدر عن التلاميذ العاديين من أنماط سلوكية؛ فالأسـاليب التى التى دأل يستخدمها المعلمون فى التعامل معها يجب أن تكون مختلفة بين كلتا لتادئ

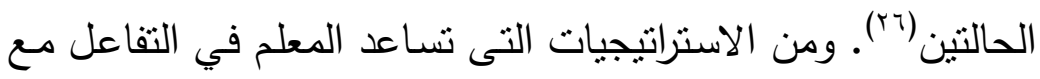
السلوكيات غير الملائمة التى تصدر من التلاميذ ذوى الاحتياجات

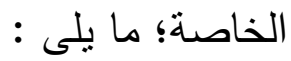

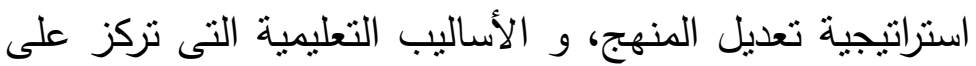

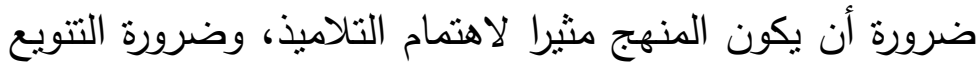
فى طرائق العرض، وفى الوسائل المستخدمة؛ بما يكفل زيادة

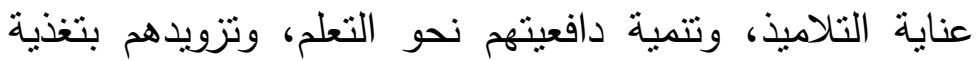


استراتيجية تفاعل الأقران، التى تركز على الأقران؛ كأحد وسائل

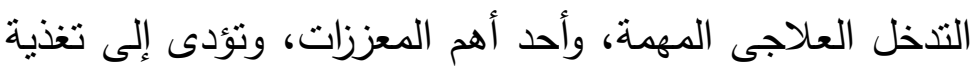
راجعة فورية، وتعمل على تعزيز السلوكيات الملائمة. اسـتراتيجية الإدارة الذاتيـة؛ وتتـــل إجـراءات تركـز على إدارة

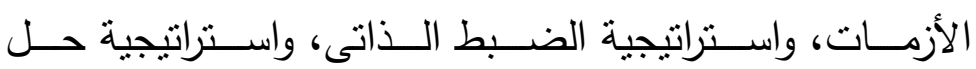
المشكلات، وقواعد الضبط الذاتى (rV).

• - تعديل الأنثطة التعليمية، وتنويعها: ينبغى أن يعمل معلمو

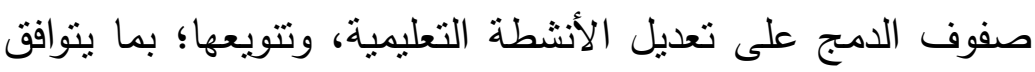

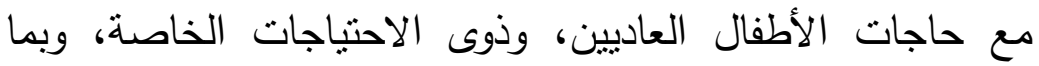

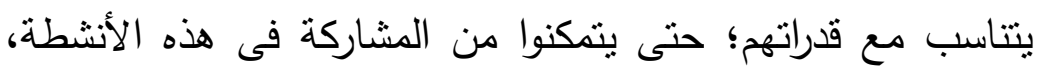

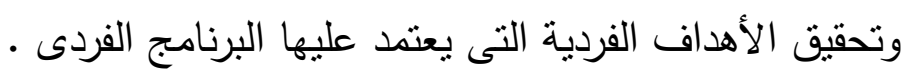

11- اختيار الوسائل التعليمية، وتعديلها، وإنتاجها : لمواجهة الحاجات التعليمية لذوى الاحتياجات الخاصة. ينبنى على المعلم استخدام وسائل تعليمية تعمل على استثمار حواس التلميذ؛ لذلك الك الك عليه الاستعانة بالصور ، والأشكال، والرسوم التوضيحية، واستخدام

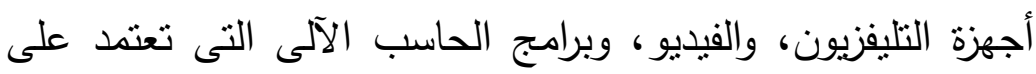

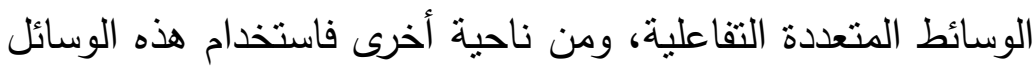

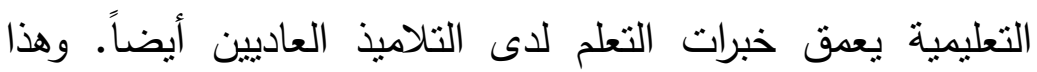
يتطلب من المعلم ما يلى :

ه المعرفة بالمعينات التكنولوجية الملائمة للتلاميذ المدمجين.

القدرة على إنتاج وسائل تعليمية بديلة .

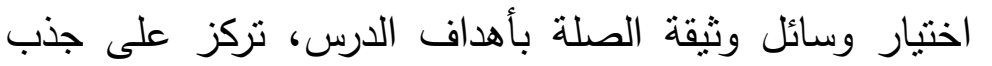
انتباه التلاميذ ذوى الاحتياجات الخاصة. 
مراعاة أن تكون مصادر التعلم متكاملة مع ما يستخدمه من

طرائق تدريس (†^).

r ا- مواعمة أساليب التقويم،وتعديلها بما يتناسب مع كل التلاميذ (العاديين وذوي الاحتياجات الخاصة )على السواء: هناك وسائل متعددة يمكن أن يلجأ إليها المعلم؛ لقياس مدى تقدم تلاميذه؛ ومنها

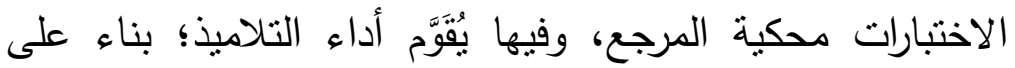
مستوى محدد من الإتقان ضمن المنهج الدراسى، والاختبارات معيارية المرجع؛ وفيها يُقَارن أداء التلميذ بأداء أقرانه، وعلى كل الإنى معلم تحديد الأسلوب الأمنل لتقويم تلاميذه. وتعتمد أساليب التقويم فى صفوف الدمج على ما يعرف بالتقييم متعدد الجوانب؛ تمثيا مع نظرية الذكاءات المتعددة التى تؤكد تعدد قدرات التلاميذ. ومن

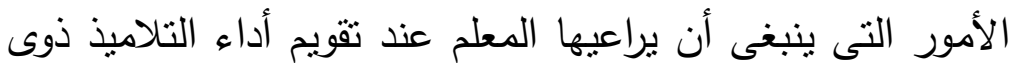

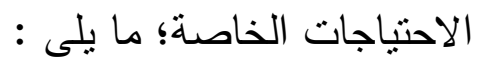
بساطة، وسهولة صياغة الأسئلة، ووضوح التعليمات . استخدام أوراق العمل ذات المستويات المختلفة فى تقويم أداء التلاميذ.

ضرورة أن ترتبط أسئلة التقويم بأثنياء واقعية من البيئة المحيطة.

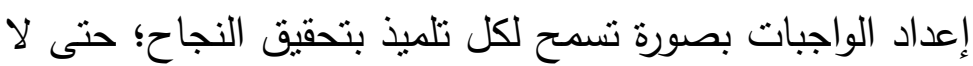
يشعر التلميذ بالإحباط. اختصار كم الواجبات؛ بحيث تركز على النقاط الأساسية فى بـ الموضوع دون اللجوء إلى التفاصيل(rq). با - العمل فى فريق : تعد الشراكة بين المعلم العادى، ومعلم التربية الخاصة، والعمل معا كفريق منذ بداية العام الدراسى أمراً ضرورياً

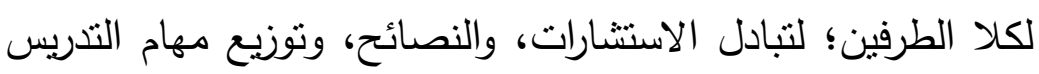


فيما بينهم، وتتظيم جدول العمل، ومواجهة المشكلات التى قد تطرأ. ويمكن تحديد أوجه التعاون بين المعلم العادى، ومعلم التربية الخاصة فى صفوف الدمج على النحو التالى :

تحديد جوانب القوة، و الضعف لاى التلميذ ذوى الاحتياجات الخاصة .

تيسير الفرص للتلاميذ ذوى الاحتياجات الخاصة للتفاعل

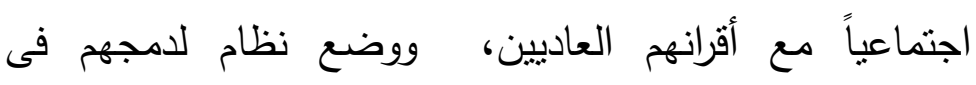
النشاطات . تكييف المنهج؛ ليلائم احتياجات ذوى الاحتياجات الخاصة.

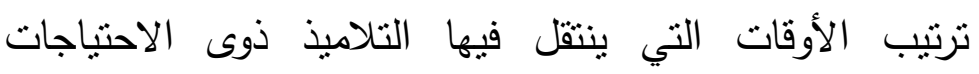
الخاصة من الصف العادي إلى المكان الذي سوف يتلقى فيه التلميذ الخدمات المباشرة من معلم التربية الخاصة؛ بحيث لا يتم

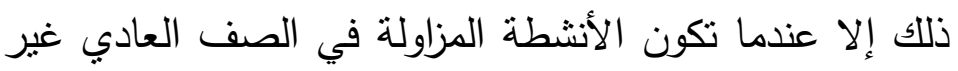

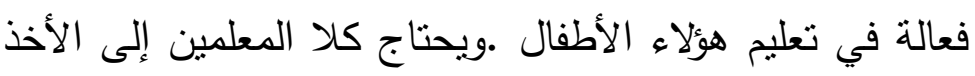

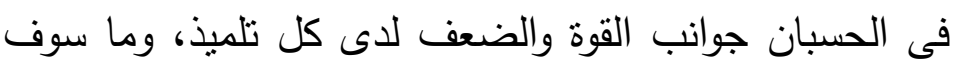
يفتقده في الصف العادي خلال فترة الانتقال، وكيف يشعر التلميذ بهذا الجزء من اليوم، وهكذا.

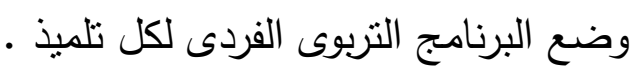

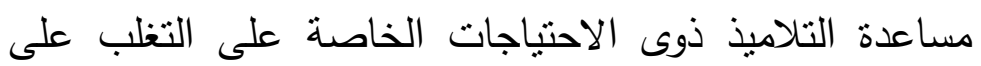
المشكلات الأكاديمية الناجمة عن الإعاقة، واكسابهم المهارات التواصلية والاجتماعية التى تمكنهم من النجاح ليس فى المدرسة فحسب وإنما فى الحياة بوجه عام.

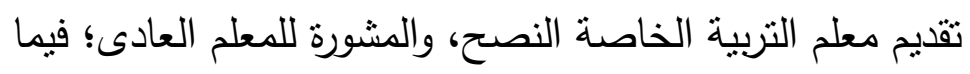
يتعلق بطرائق تدريس بعض المواد الأكاديمية، وأساليب 
الامتحانات، ومساعدته فى فهم الأسس السليمة لكيفية التعامل

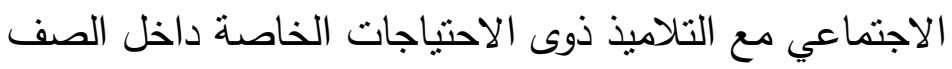
وخارجه، و نزويده عند الحاجة بالكتيات، والمنشورات، والوسائل

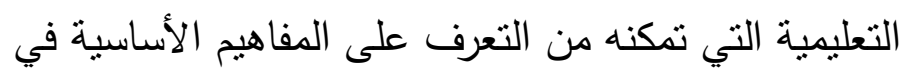
مجال الإعاقة. يُدَرِّ معلم التربية الخاصة المهارات الخاصة التى لا يسنطيع

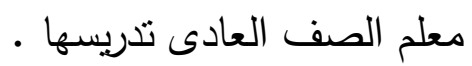

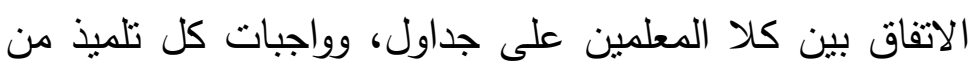

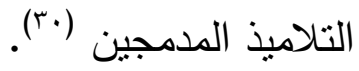
ه - إعـاد ســلات منفصـلة عـن كـل تلميــ : يحتـاج المعلم إلىى

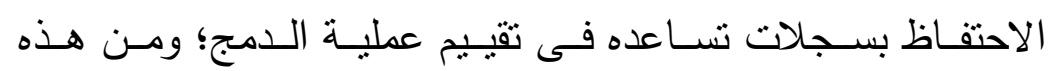

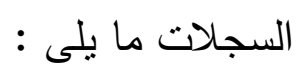

سجل لتدوين المعلومات حول تطور الطفل ذوى الاحتباجات

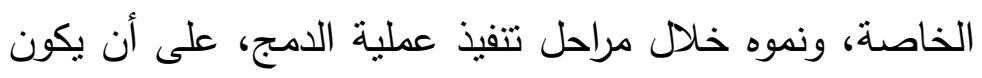
التسجيل دورياً، وبشكل مستمر؛ بما يكفل المتابعة المستمرة

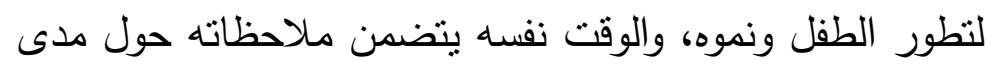

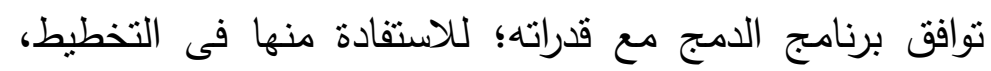

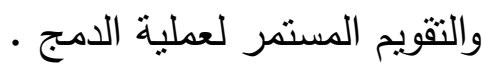
سجل تقويمى خاص يحدد مدى استفادة الطفل ذوى الاحتياجات

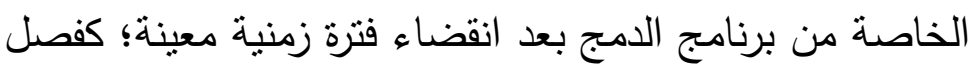

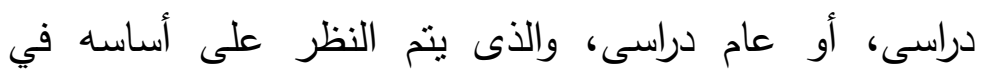

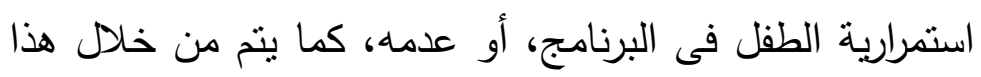

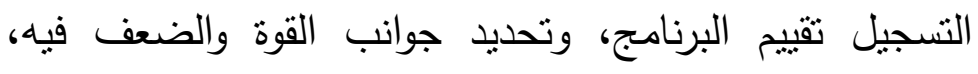


وإجراء التعديل المناسب فى ضوء الخبرة التى اكتُبِبَتْ خلد فترة

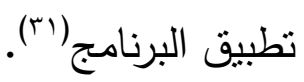

1 1 - الاتصال، والتعاون، والتتسيق المستمر مع أولياء الأمور :

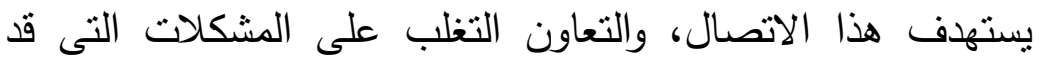
تطرأ على عملية الدمج، وتحديد الأدوار التى ينبغى على أولياء

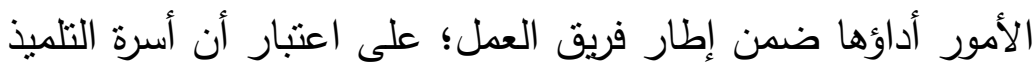

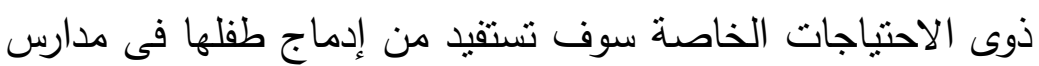

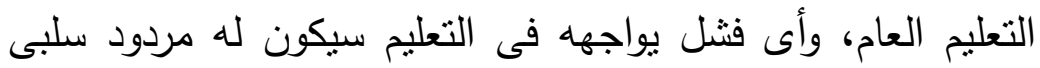
على الأسرة؛ لذلك فمشاركة الأسرة فى جميع خطوات تخطيط برنامج

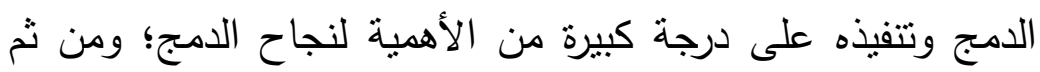
يجب على المعلم إقامة علاقة إيجابية بينه، وبين أولياء أمور

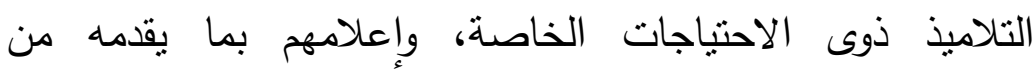

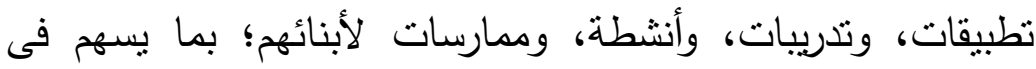

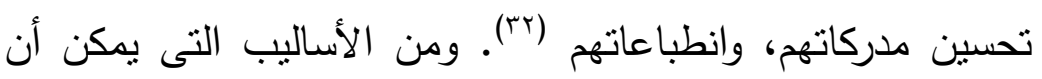

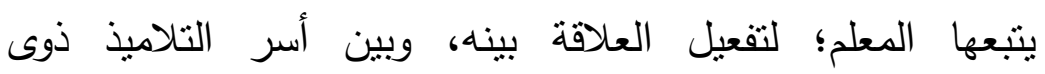
الاحتياجات الخاصة؛ ما يلى : لئه

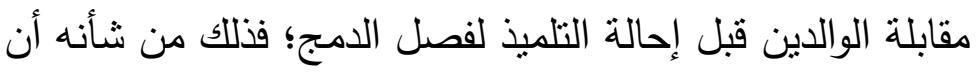
يوفر للمعلم فرصة التواصل الإيجابى قبل بداية العام الدراسي. تعريف الوالدين بالطرائق التى يمكنهم من خلالها تقديم المساعدة . تطوير الواجب المنزلى؛ بحيث يشجع الأسرة على المشاركة؛ من

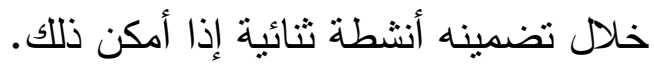

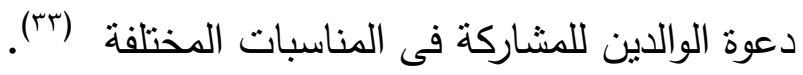




\section{ثانياً: الاحتياجات التدريبية}

تعد الاحتياجات التدريبية القاعدة الأساسية التى تتطلق منها عملية تخطيط البرامج التدريبية المختلفة وتصميمها، وهى تمثل الحلقة الأولى لنى

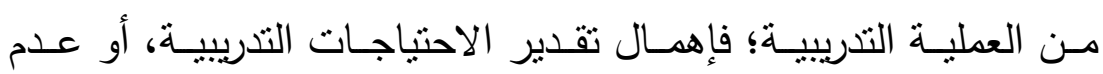
تحديدها بدقة؛ يفقد جدوى البرامج التدربيية، كما أن تحديد الاحتياجات التدريبية يمثل نقطة البداية لنجاح برامج التدريب ، وعلى أساسه يتم تقويم هذه البرامج التدريبية .

\section{1-مفهوم الاحتياجات التّريبية ، وأهدافها:}

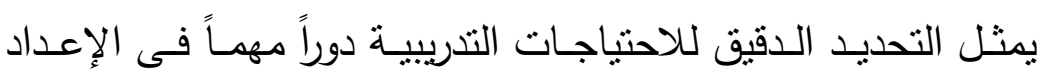

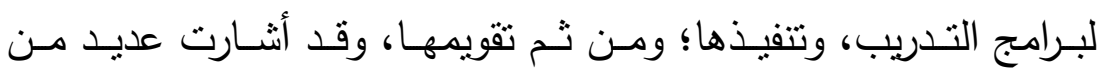

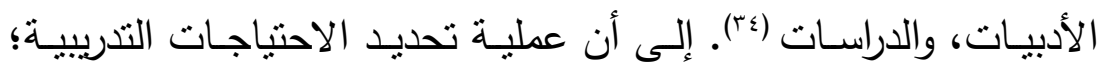

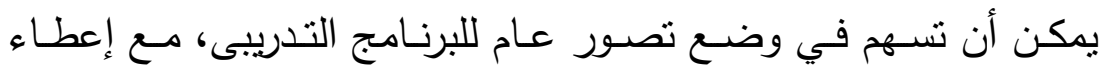

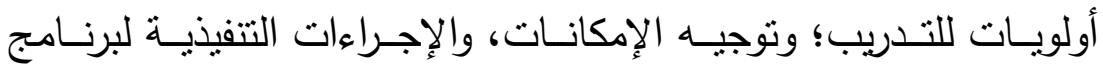
التدريب؛ بما يكفل تحقيق الأهداف المرجوة. وتتشأ الحاجة للتدريب عندما تكون هناك فجوة بين ما يمتلكه الفرد، وبين ما ينبغى أن يمتلكه فى مجال ما؛ حيث تعرف الاحتباجات التدريبية

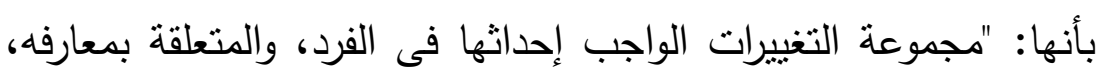
ومهاراته، وأدائه، وسلوكه، واتجاهاته؛ لكى يتمكن من أداء وظيفته

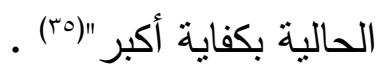

كذللك يرى البعض أنها: معلومات، واتجاهات، ومهارات يراد تتميتها،

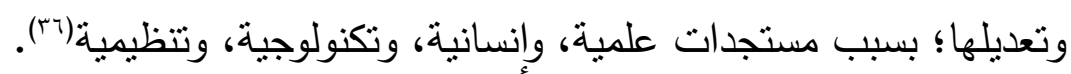

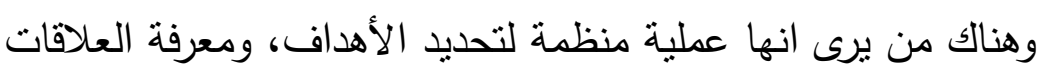
بين الحاجة الفعلية، والمرغوبة مع وضع أولويات للعمل (rv).

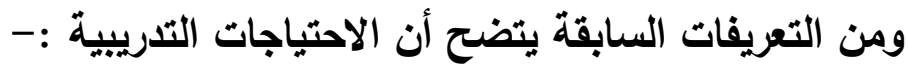


تمنت الأسلوب العلمى لقياس الفرق بين المستوى الحالى للفرد (قبل التدريب)، والمستوى المراد الوصول إليه (بعد التدريب). تتضمن جوانب معرفية، وفنية، ومهارية، وانسانية . لا تقتصر على نواحي ضعف، أومشكلات محددة، يراد حلها فحسب؛ وإنما تتضمن جوانب تطويرية يراد تتميتها، أو تعديلها. عملية مستمرة، ودائمة؛ بسبب المستجدات العلمية، والإنسانية، والتكنولوجية، والتتظيمية. هى أهداف يسعى التدريب إلى تحقيقها.

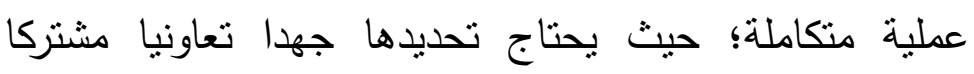
يضطلع به عدد من الجهات، والأفراد .

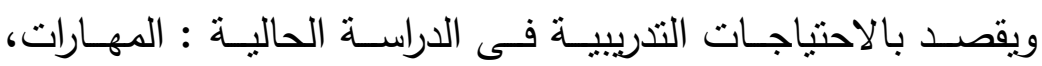

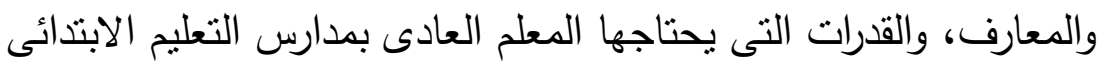

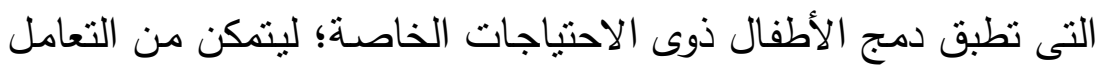

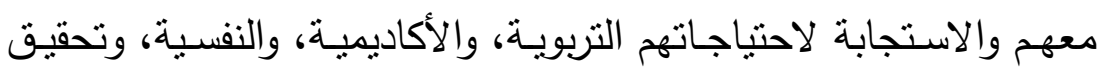
أهداف دمجهم. ويمكن تحديد الأهداف التى تسعى الاحتباجات التدريبية إلى تحقيقها فيما يلى : •توضيح الفئة المستهدفة من التنريب، ومجالات التدريب اللازمة لهم، والنتائج المتوقعة منهم. تقدير الاحتياجات التدريبية المستقبلية. مساعدة القائمين على إدارات التدريب فى وضع استراتيجيات، وخطط طويلة المدى لهيكل التدريب، وتتظيمه، وتوجيه سياساته،

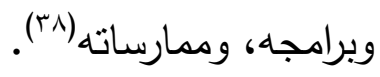




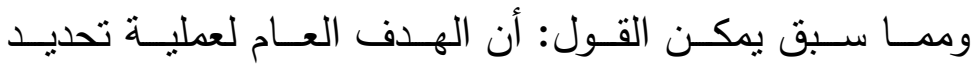

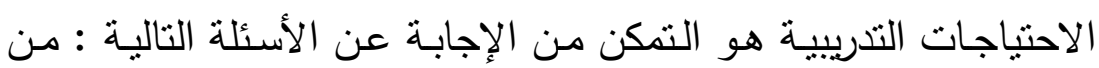

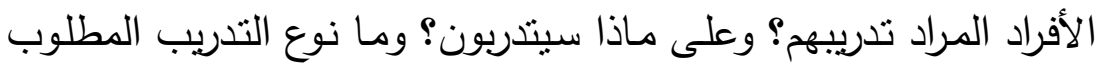

لهم ؟ وما النتائج المنوقعة منه؟ r - ب مجالات الاحتياجات التدريبية ، وأنواعها: تتضمن الاحتياجات التدريية ثلاثة مجالات رئيسة هى :

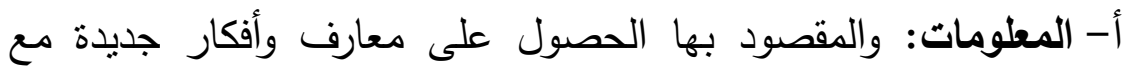
فهمها، واستيعابها إلى الحد الذى يستطيع عنده المعلم التعبير عن هذه

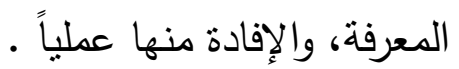

ب- المهـارات : أى اكتسـاب المعلم القدرة على استخدام وسـائل جديدة

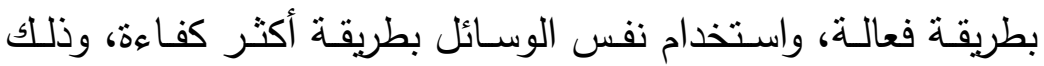
يستلزم الممارسة، والتفاعل الصحيح فى الموقف التدريبي.

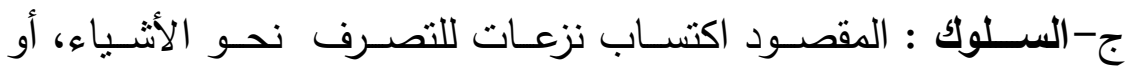

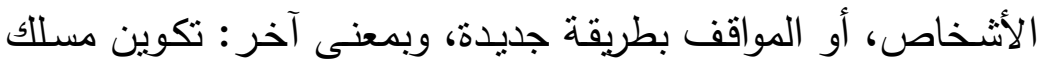
ذهنى، أو عادة فكرية إيجابية تجاهه (9").

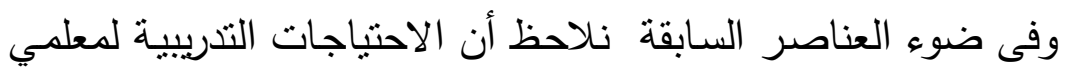

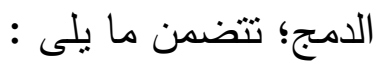

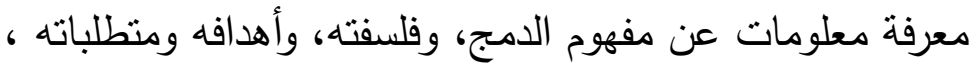
وخصائص الأطفال ذوى الاحتياجات الخاصة ، وغيرها من لن المعلومات التى تسهم فى تحسين أداء المعلم. اكتساب القدرة على تعديل طرائق التدريس، وتتويعها ، وتعديل

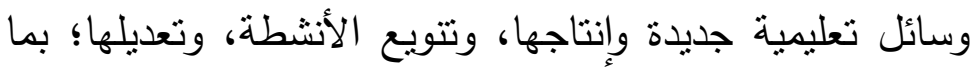

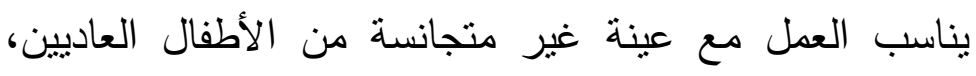
وذوى الاحتياجات الخاصة. 
تتمية اتجاهات إيجابية نحو عملية الدمج ، والتلاميذ ذوى

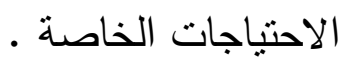

\section{وتتعدد أنواع الاحتياجات التدريبية؛ فهناك من صنفها إلى :}

أ- احتباجات عادية ( منتظمة): تتعلق بتدريب العاملين الجدد، أو عند

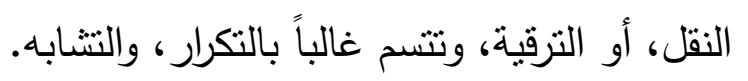

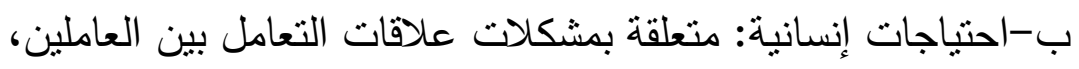

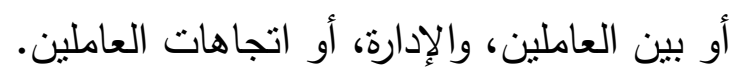

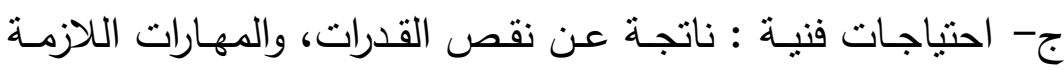

$$
\text { للعمل. }
$$

د- احتياجات تطويرية، وإبداعية : لتطوير القدرات الذهنية للأفراد؛ لتلبية احتباجات المنظمة للتطوير، ولمواكبة المتغيرات التكنولوجية،

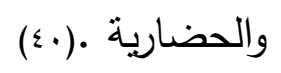

\section{وهناك من صنفها إلى نوعين رئيسين؛ هما:}

\section{احتياجات تدريبية طويلة الأجل، وأخرى قصيرة الأجل : حيث}

تمثل الاحتياجات التدريبية طويلة الأجل الفرق بين مستوى الأداء

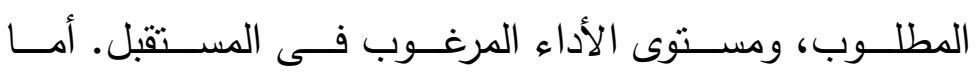

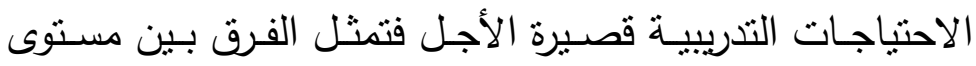
الأداء المطلوب، ومستوى الأداء الحالى.

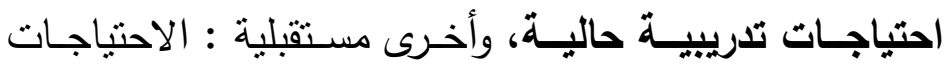

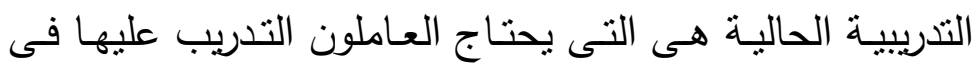
الوقت الحاضر ، أما الاحتياجات التدريبية المستقبلية فهى التى لتى سبحتاج العاملون التدريب عليها فى المستقبل؛ نظراً للتغييرات

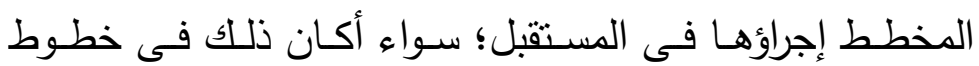


الإنتـاج، أو الخدمات، أو فـى وسـائل و العهـل وأدواتـه، أوفى الكى

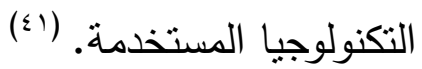

r- الجهات المسئولة عن تحديد الاحتياجات التدريبية :

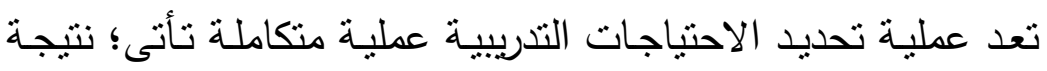

جهود مشتركة بين عدد من الجهات، والإفراد المسئولين عن تحديد تلك تلكيه

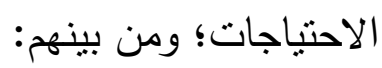

الفـرد ( المتــدرب) : ويعد مصدراً أساسياً فى تحديد الاحتياجـات

التذريبية المبرد

المدير، أو الرئيس المباشر: وهو الذي يشرف على العمل، ويعرف

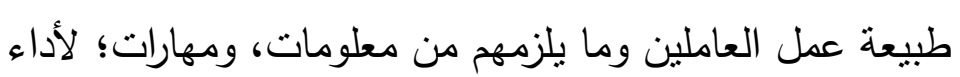
العمل على أكمل وجه.

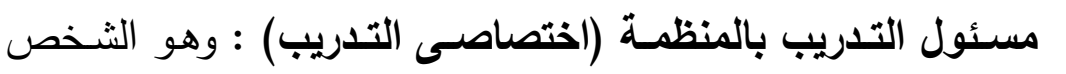

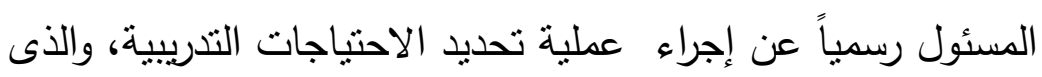

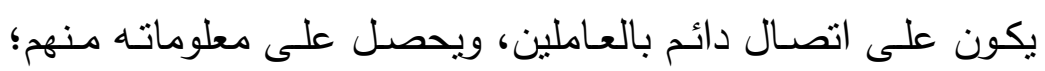

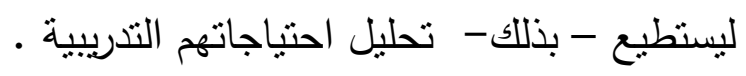

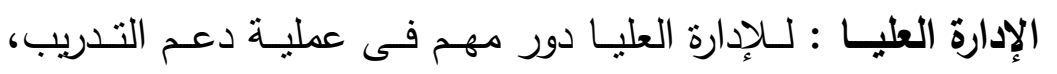

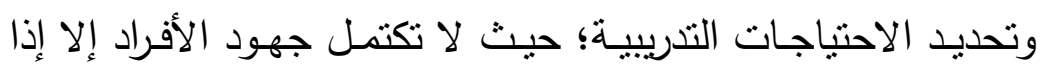
كان هناك تأييد من الإدارة العليا لتيسير مهامهم.

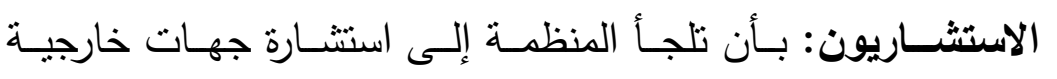

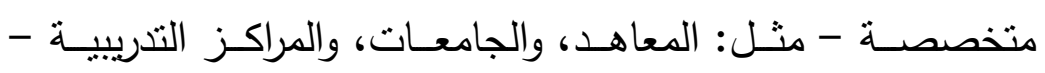

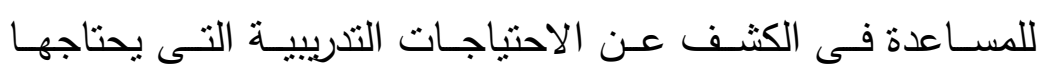

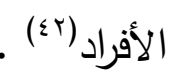

ممـا سـبق يلاحظظ أن مسئولية تحديـ الاحتياجـات التدربييـة عمليـة

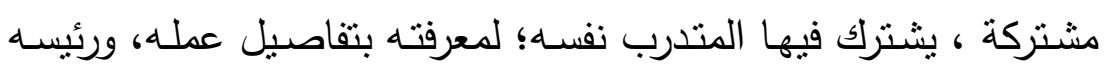


المباش؛ لمعرفته بطبيعة عمل الأفراد، وما يلزمهم من معارف، ومهارات لأداء العمل، ومسئول التدريب؛ لأنه على اتصال دائم بالمتدربين، فضعلاً

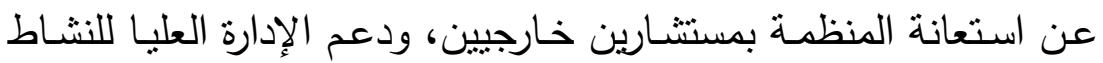
التدريبي.

وقد اعتمدت هذه الدراسة - فى تحديد الاحتباجات التدريبية - على المعلمـين (المتـدربين)؛ فهم الأقددر على تحديـد احتياجـاتهم التدريبيـة بنفسـه؛ لمعرفتهم بتفاصيل العمل، وجزئياتـ، مـن ناحيـة، واحتياجـاتهم الذاتية من ناحية أخرى؛ أب: احتياجاتهم المعرفية، والمهارية، والإنسانية. ع - أساليب؛ ومداخل تحديد الاحتياجات التدريبية :

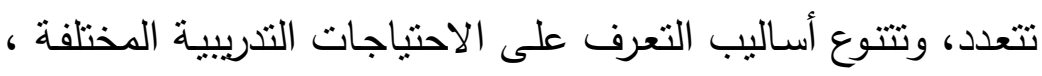
والتى يترتب عليها تصميم برامج التدريب، والتتميـة البشرية، وتتفيذها، ومن هذه الأساليب ما يلى : لبابلى

المقابلــة الثخصـية : يعـد أسـلوب المقابلـة الثخصـية مـن أنجـح

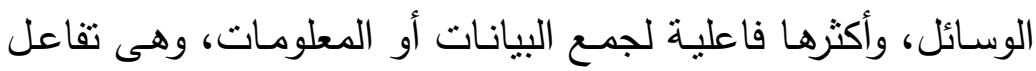
بين شخصين: القائم بالمقابلة (خبير / مسئول التدريب)، والمتدربين المحتملين؛ وذللك وجهاً لوجه بتوجيه أسئلة، وتلقى الرد عليها.

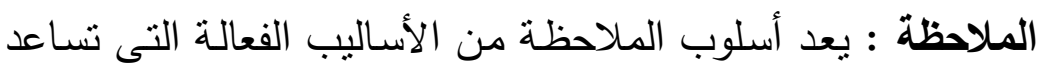

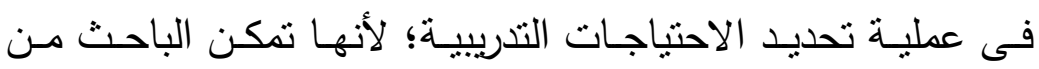

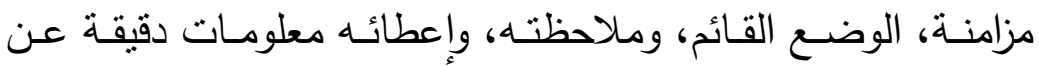
الحالة.

الاختبارات : تعد وسيلة جيدة لملاحظة أداء الأفراد، وشرحه فى ظل ظروف مراقبة؛ بقصد قياس أداء الأفراد فى وظائفهم الحالية؛ للتعرف

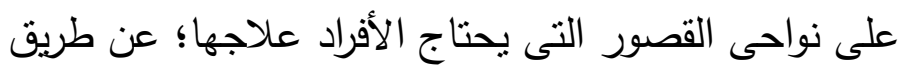


التدريب، وقد تجري المنظمة اختبارات معينة؛ سواء أكانت اختبارات القدرة، أو الاستعداد، أو المهارة، وغيرها.

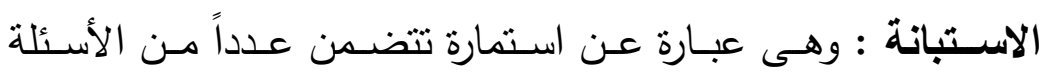

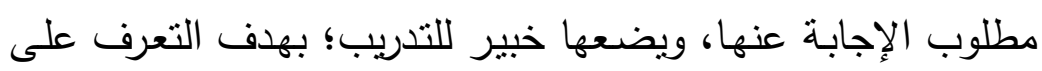

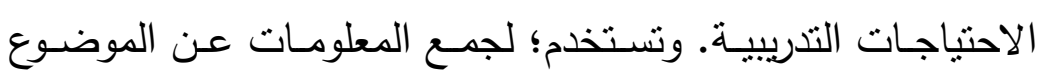
المراد بحثه.

تحليل المشكلات: من أهم وسائل نجاح التدريب تحليل مشكلات العمل، ومعرفة السبب الحقيقى للمشكلة؛ حيث أسهم التدريب في حل

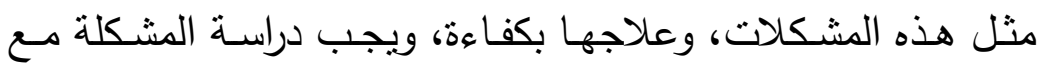

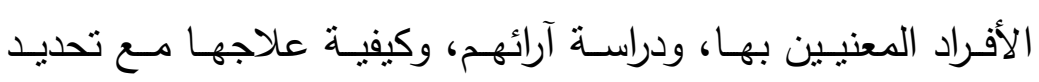

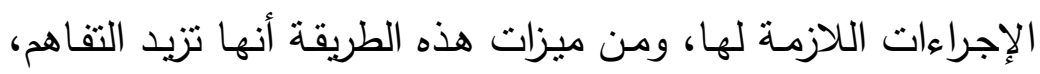
والاتفاق بين الرؤساء، والمرؤوسين. دراسة السجلات والتقارير: نظهر دراسة السجلات، والتقارير نقاط لترؤين الضعف التى تحتاج علاجها بالتدريب، ومن أهم ميزات هذه الطريقة

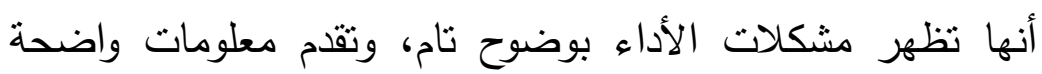
للرؤساء، ولمسئولى التدريب، وتقديم مقترحات لحل المشكلات وتحدد التدريب اللازم لها.

تقييم الأداء: تعد عملية تقييم الأداء عملية مستمرة؛ حيث يخضع لها كل فرد فى المنظمة، وفى أى مستوى وظيفى، وتنساعد هذه الوسيلة

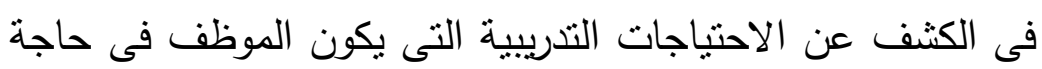
إليها؛ عن طريق التدريب. قوائم الاحتياجات: بحيث بعطى الموظف قائمة تحتوى عدداً من الفقرات، تمثل الأعباء التى يؤديها فى وظيفته، والاحتياجات التدريبية التى يمكن أن تكون لايه، ويطلب منه أن يحدد البنود التى تمثل 
حالته، أو تتطبق عليه، وتنساعد هذه الطريقة فى تحديد الاحتباجات

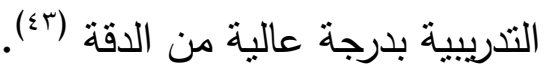

وقد أثنـارت الأدبيـات فى مجـال التدريب إلى أن هنـاك ثلاتثة مـداخل لتحديد الاحتياجات التدريبية؛ وهي: أ- مدخل تحليل المنظمة : حيث يهدف إلى دراسة المنظمة ككل؛ من وهن حيث: الأهداف، و الموارد، وأساليب العمل والإنتاج ، ثم تحليل الهيكل، والمناخ التظيميان.

ب- مدخل تحليل الوظيفة : يمكن من خلاد دراسة قوائم توصيف

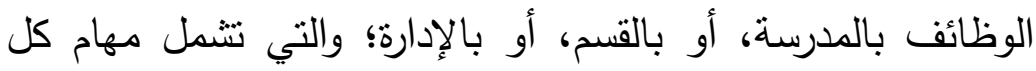
وظيفة ( مشرف، مدير مدرسة، معلم ،... )، والمواصفات اللازم توافرها في شاغلي الوظائف، و الخروج ببعض المؤشرات التدريبية؛ مثل :

اختلاف مهارات العاملين، وقدراتهح عن متطلبات الوظائف .

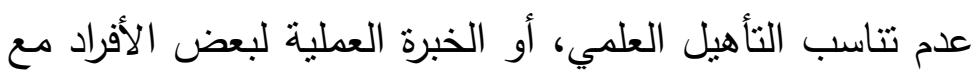
منطلبات أداء وظائفهر.

اختلاف أنماط السلوك الفعلي للأفراد عن الأنماط المرغوب فيها؛ كما تحددها قوائم توصيف الوظائف .

ج- مدخل تحليل الفرد : يتتاول هذا المدخل مستوى أداء الفرد الفعلي فى وظيفة مـا، وتحديد مستلزمات الوظيفة، ومدى إمكانية الارتقاء

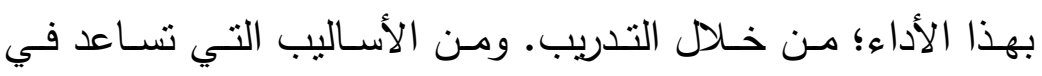
التقيبم الموضوعي ( أسلوب الملاحظة، و المقابلة، وبطاقات تقويم

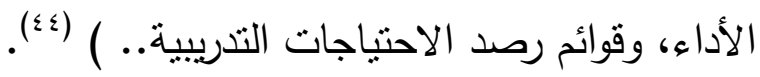

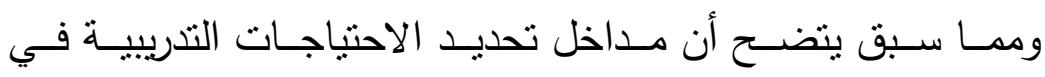

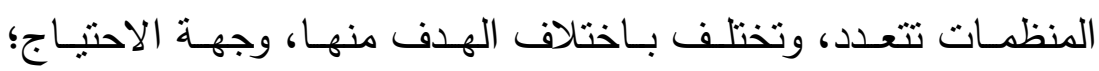

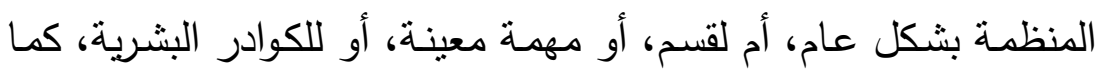


تختلف باختلاف الأداة المستخدمة فيها لجمع المعلومات، وطبيعة العمل

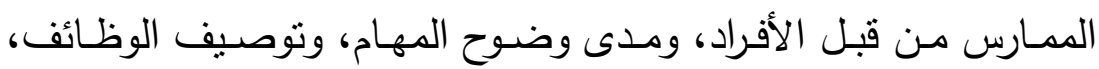
ونوعية الأفراد في المنظمة. ه - معايير تحديد الاحتياجات التدريبية :

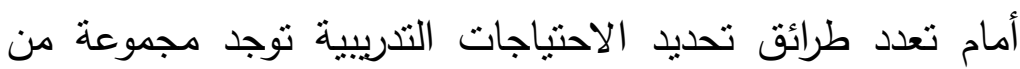

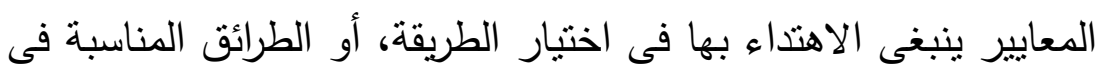

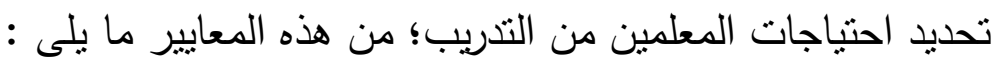
ه المشاركة : أن تتطلب الطريقة مشاركة كل الأعضاء . الكفاية : إمكانية استخدام الطريقة فى أثناء وقت العمل فى المنظمة. التقرقة بين المشكلات : أن يفرق الإجراء المستخدم بين المشكلات ، ويصنفها إلى فئات حسب مصادرها، وطبقاً للحلول المتاحة . الانطباعـات الوجدانيـة : أن يسفر استخدام الإجراء عـن استشـفاف وطن لمشاعر العاملين تجاه المنظمة، ومشكلاتها.

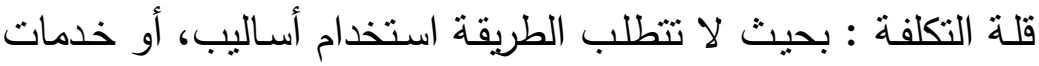
مكلفة .

الوقت المطلوب: يعد الوقت المخصص لجمع البيانات، وتحليلها قبل

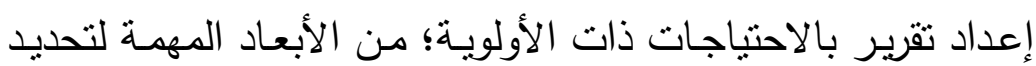

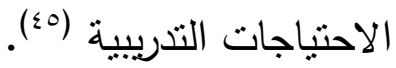
צ- متطلبات نجاح تحديد الاحتياجات التدريبية : يرتبط نجاح عملية تحديد الاحتياجات التدريبية بمدى توافر مجموعة من المتطلبات؛ منها: كفاءة من يحدد الاحتياجات التدريبية . • توفر البيانات، والمعلومات الضرورية لكافة الأفراد المراد تدريبهم 
• • توفر كافة المستتدات، والوثائق الني توضح المعلومات الخاصة

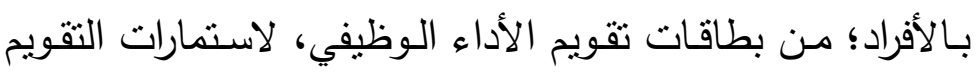

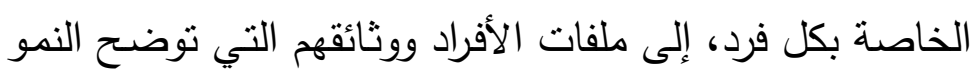

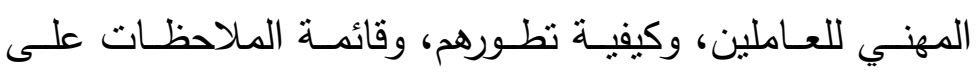

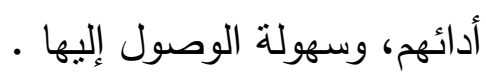
• ثقافة الأفراد المراد تدريبهم ، وتقبلهم محدد الاحتياجات التندريبية توافر الوقت المناسب لتحديد كافة الاحتياجات التندريبية .

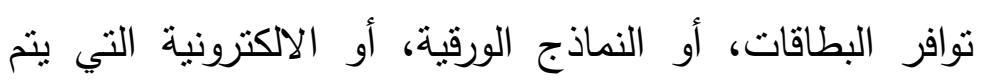
تعبئة الاحتياجات التدريبية فيها لكل متدرب .

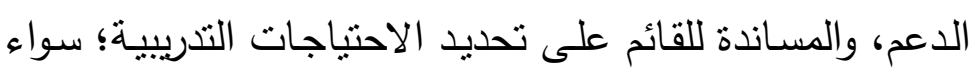

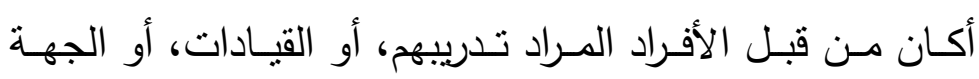

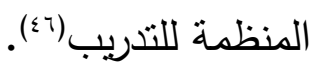

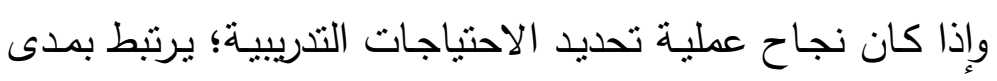

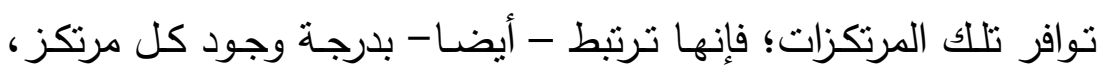

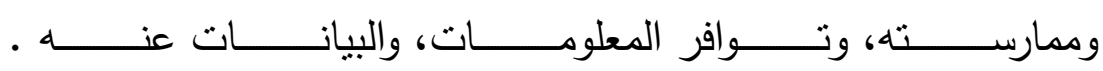
ثالثا : الاحتياجات التدريبية لمعلمى فصول الامج :

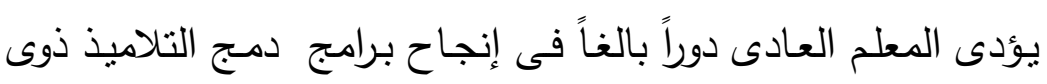
الاحتياجات الخاصة بمدارس التعليم العام؛ وهذا يتطلب تدريبه؛ للوفاء

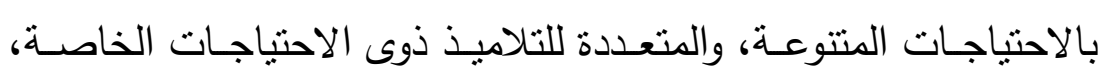

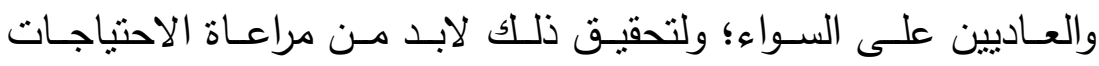

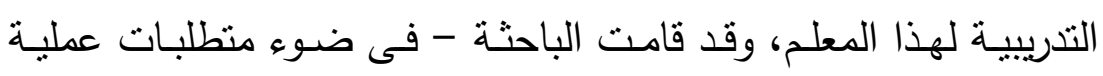

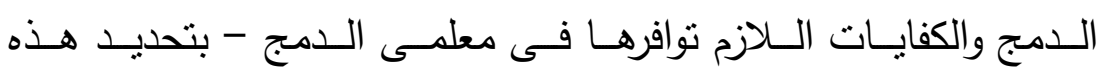
الاحتياجات وفقا للمحاور الآتية :

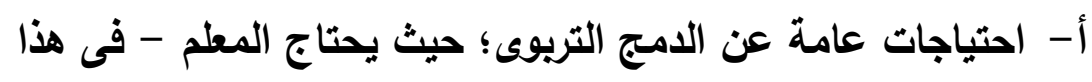

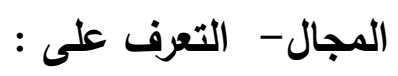


• فلسفة الدمج، ومبادئه ، وأنثكاله ، ومتطلباته.

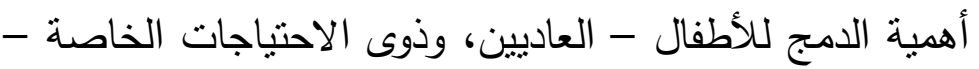

والمعلمين.

• الأدوار المنوط بها المعلم العادى بمدارس الدمج.

أدوار معلم التربية الخاصة بمدارس الدمج.

• المستجدات التربوية فى مجال الدمج.

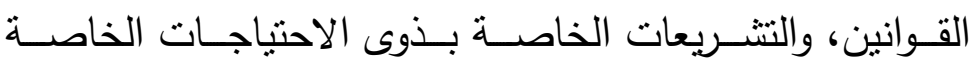

والتشريعات، والقرارات الوزارية المنظمة لعملية الدمج.

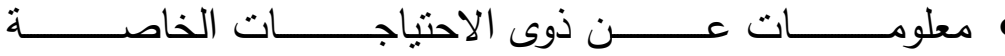

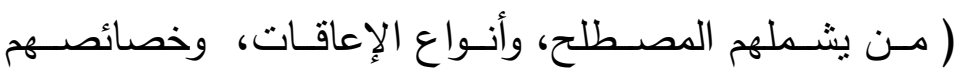

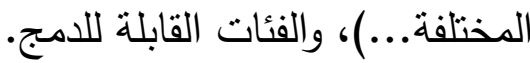

ب-احتياجات تدريسية؛ يحتاج المعلم فى هذا المجال:

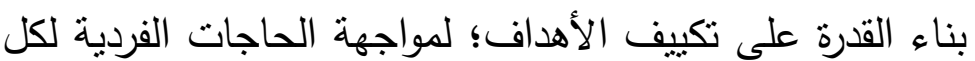

طفل.

بناء القدرة على تخطيط الدرس، وتتفيذه؛ بما يتتاسب واحتباجات

الأطفال العاديين، وذوى الاحتباجات الخاصة، وقدراتهم.

• الإلمام بطرائق تدريس الأطفال ذوى الاحتباجات الخاصة . ل.

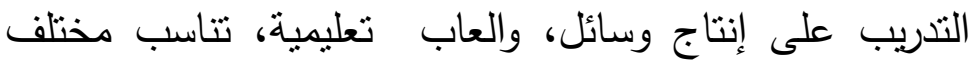

الإعاقات.

التدريب على استخدام الأجهزة التكنولوجية، والثقنيات الحديثة،

وتوظيفها؛ للوفاء باحتياجات ذوى الاحتياجات الخاصة التربوية،

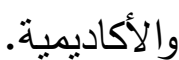


التدريب على استخدام استراتيجيات تعليمية مناسبة لمستويات الأطفال ذوى الاحتياجات الخاصة؛ مثل: التعلم الفردي، والتعلم

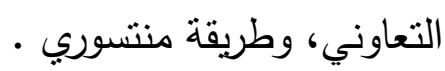
التدريب على تكييف المناهج؛ لكي تتلاءم مع أنماط الاحتياجات التربوية، والأكاديمية للتلاميذ ذوى الاحتباجات الخاصة. بناء القدرة على تصميم، وتعديل أنشطة تعليمية، تتاسب التلاميذ

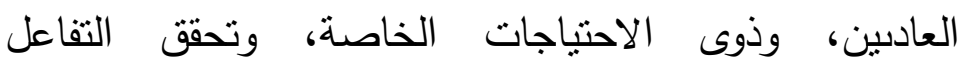

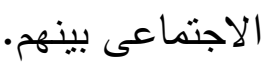
بناء القدرة على وضع أنشطة إثرائية، وعلاجية؛ لتعليم ذوى

$$
\text { الاحتياجات الخاصة. }
$$

ا التدريب على وضع خطط تربوية فردية للتلاميذ ذوى الاحتياجات الخاصة .

$$
\text { • التدريب على العمل التعاونى، والعمل فى فريق. }
$$

ج- احتياجات سيكولوجية وصفية؛ يحتاج المعلم فى هذا المجال: بناء القدرة على تحديد الاحتياجات النفسية للتناميذ العاديين، وذوى الاحتياجات الخاصة، وكيفية تلبيتها. التعرف على أساليب الإرشاد النفسي للتلاميذ ذوى الاحتياجات لئهات الخاصة. تكوين اتجاهات إيجابية نحو العمل مع التلاميذ ذوى الاحتياجات الخاصة. هالتعـرف علـى أسـاليب توجيـهـ التلاميـذ العـاديين، وإرثــادهم لمساعدتهم فى تقبل أقرانهم ذوى الاحتياجات الخاصة. التعرف على أسـاليب تهيئة التلاميذ ذوى الاحتياجـات الخاصـة

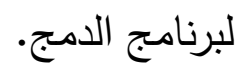


التعرف على المشكلات التى قد تتنج عن الاحتكالك بين التلاميذ

العاديين، وذوي الاحتباجات الخاصة، وكيفية التغلب عليها.

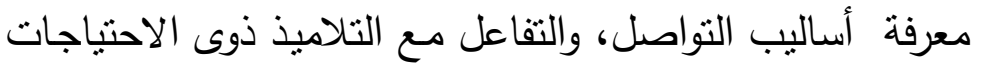

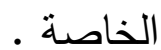

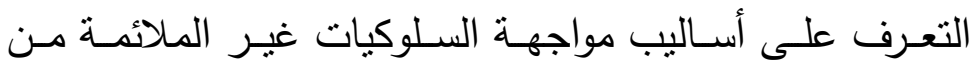
التلاميذ ذوى الاحتباجات الخاصة. ا التعرف على أساليب تدريب التناميذ ذوى الاحتباجـات الخاصـة على اكتساب السلوكيات الإيجابية. بنـاء القدرة على تحديد الفروق الفردية بين التلاميذ ذوى

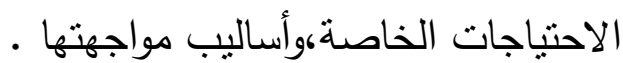
اكتساب مهارة إعداد البيئة الصفية بطريقة تسمح للتلاميذ ذوى

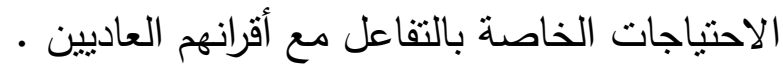

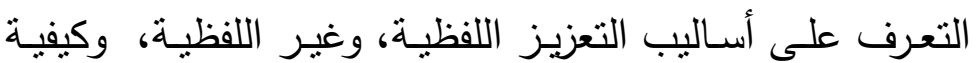
استخدام كل منها، والوقت المناسب لاستخدامها.

د - احتياجات خاصة بعملية التقويم؛ يحتاج المعلم فى هذا المجال: بنـاء القدرة على تشـخيص مـواطن الضـعف لـى التلاميذ ذوى الاحتياجات الخاصة فى النواحى التحصيلية .

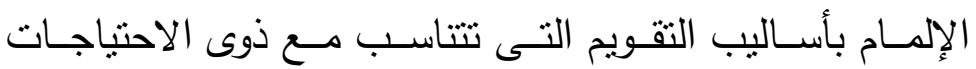
الخاصة، والفروق الفردية بينهم. التدريب على تعديل أسـاليب التقويم؛ لتتاسب قدردات الأطفال العاديين، وذوى الاحتياجات الخاصة. التدريب على بناء اختبارات تتاسب ذوى الاحتياجات الخاصة . 


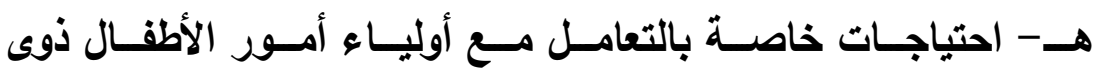

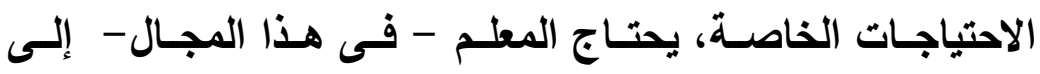

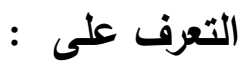

هأساليب التواصل مع أولياء أمور ذوي الاحتياجات الخاصة.

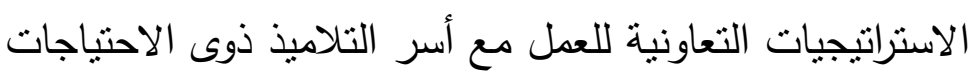

$$
\text { الخاصة. }
$$

أساليب استقصاء حاجات أسر ذوى الاحتياجات الخاصة بشان

$$
\text { أبنائهم فى المدرسة. }
$$

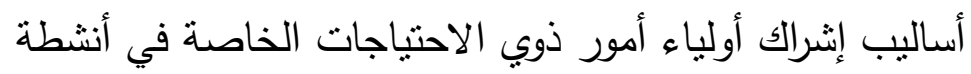

$$
\text { المدرسة. }
$$

طرائق الإرشاد النفسي لأسر ذوي الاحتياجات الخاصة.

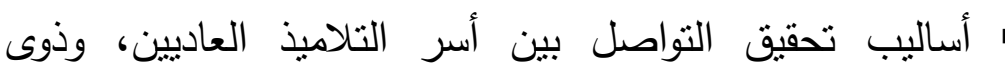

$$
\text { الاحتياجات الخاصة. }
$$

الاراسة الميدانية

\section{أهداف الدراسة الميدانية :}

تهـدف الدراسـة الميدانيـة إلى التعـرف على الاحتياجـات التدريبيـة

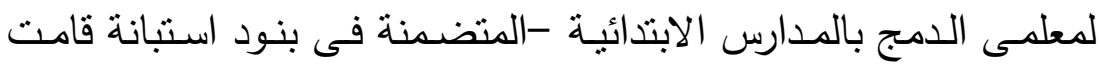

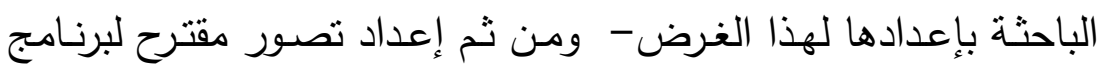
تدريبى لهؤلاء المعلمين فى ضوء احتياجاتهم التدريبية. عينة البحث والمجتمع الأصلي :

تشنكل عينة البحث جانبًا من وحدات المجتمع المعني بالبحث بحيث

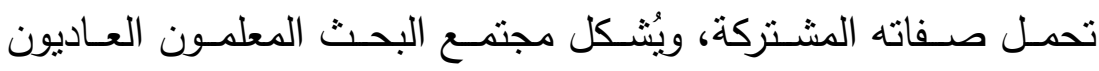
بالمدارس الابتدائية الملحق بها فصول للمج ذوى الاحتياجات الخاصـة

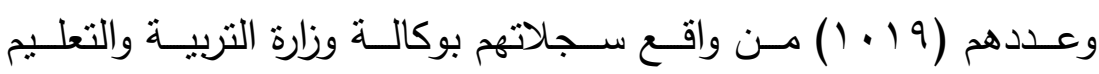


بالإسكندرية، ونظراً لصعوبة شمول البحث لجميع أفراد المجتمع الأصلي،

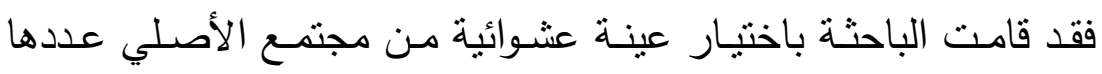

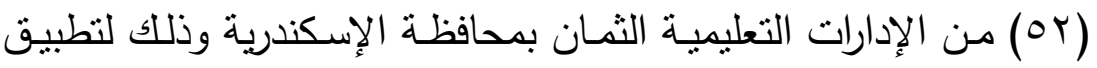

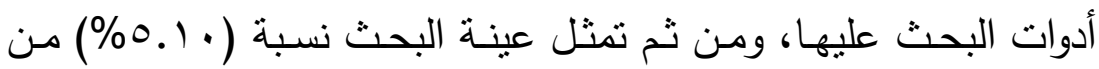

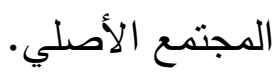
إجراءات الدراسة الميدانية : بناء أداة البحث (استبانة الاحتياجات التدريبية لمعلمى الدمج بالمدارس : لاست (الابتدائية): لجأت الباحثة إلى إعداد استبانة الاحتياجات التدريبية لمعلمى الدمج بالمدارس الابتدائية؛ لإعطاء صورة تقريبة للواقع، ومؤشر للتعرف علي الاحتياجات التدريبية لهؤلاء المعلمين. وشملت الاستبانة (0) محاور ؛ يضم كل محور مجموعة من العبارات التي روعي في تصميمها الوضوح وبساطة الألفاظ، وقد صممت البطاقة بطريقة الاستجابة في ضوء ميزان خماسي متدرج طبقاً لدرجة الاحتياج

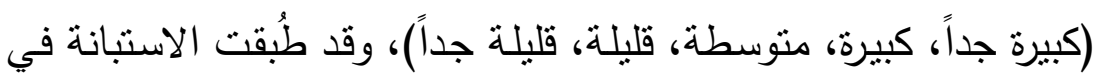

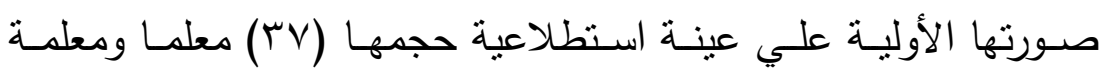
بالمدارس الابتدائية الملحق بها صفوف لدمج ذوى الاحتياجات الخاصة

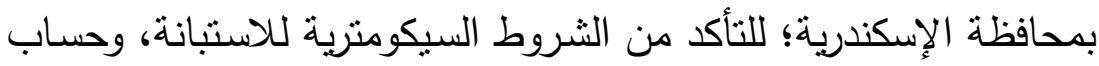

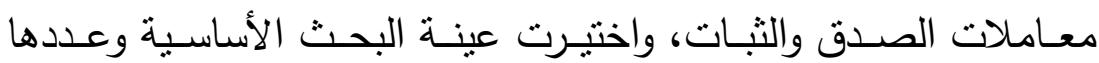

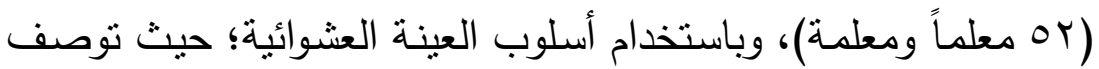
بأنها غير متحيزة؛ لكبر حجم المجتمع الأصلي. 
وفيما يلي إجراءات التأكد من الثروط السيكومترية لأداة البحث: صدق استبانة الاحتياجات التدريبية لمعلمى الامج بالمدارس الابتدائية:

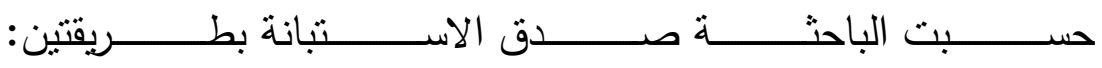

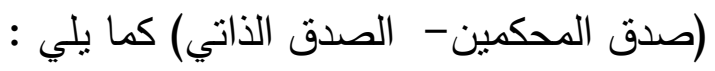
أولاً: صدق المحكمين أنَ

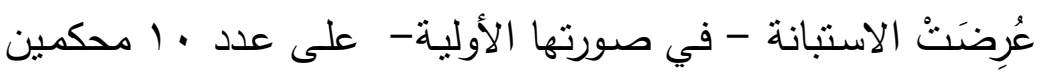
من السادة أساتذة التربية بالجامعات المصرية مصحوبة بمقدمة تمهيدية، تضــنت توضــــاً لمجـال البحـث، والهـدف منـه، والتعريـف الإجرائسي

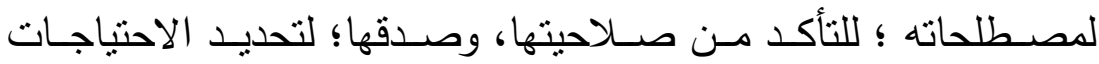
التدريبية لمعلمى الدمج ، وإبداء ملاحظاتهم عن مدي: ارتباط مفرداتها بالهدف الذى تقيسه.

كفاية مفردات الاستبانة؛ للتعبير عن الهدف الذى تقيسه.

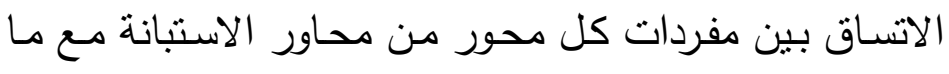

يقيسه.

وضوح تعليمات الاستبانة.

هكل الاستبانة، ومضمونها.

وقد حسبت الباحثة نسب اتفاق المحكمين السادة أعضاء هينه هيئة التدريس بالجامعات علي كل مفردة من مفردات الاستبانة؛ من حيث: مدي تمثيل

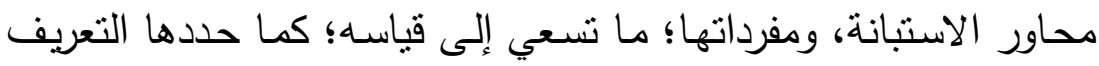
الإجرائي؛ كما يوضحها جدول رقم (1) 
جدول رقم (1) نسب اتفاق المحكمين من السادة أعضاء هيئة التدريس بالجامعات علي كل عبارة من عبارات استبانة الاحتياجات التدريبية لمعلى الامج بالمدارس الابتدائية (ن= • 1)

\begin{tabular}{|c|c|c|c|c|c|c|c|c|c|c|c|}
\hline نسبة الاتفاق & عرات & مرات & ? & الاتفاق & الاختلاف & مرات & s & الاتفاق & 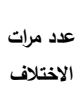 & مرات & r \\
\hline$\% 1 \ldots$ & 1 & 9 & 11 & $\% \wedge$. & r & $\wedge$ & $\wedge$ & \multicolumn{4}{|c|}{ احتياجات عامة } \\
\hline$\% 1 \ldots$ & 1 & 9 & ir & $\% \wedge$. & r & $\wedge$ & 9 & $\% \wedge$. & r & $\wedge$ & 1 \\
\hline \multicolumn{4}{|c|}{ احتياجات خاصة بعملية التقويم } & $\% 1 \ldots$ & . & 1. & 1. & $\% q$. & 1 & 9 & r \\
\hline$\% 1 \ldots$ & · & 1. & 1 & $\% 9$. & 1 & 9 & 11 & $\% q$. & 1 & 9 & $r$ \\
\hline$\% q$. & 1 & 1. & r & \multicolumn{4}{|c|}{ احتياجات سيكولوجية وصفية } & $\% q$. & 1 & 9 & 7 \\
\hline$\% 1 \ldots$ & · & 1. & $r$ & $\%$ \%. & 1 & 9 & 1 & $\% q$. & 1 & 9 & $v$ \\
\hline$\% 1 \ldots$ & . & 1. & 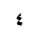 & $\% q$. & 1 & 9 & r & $\% q$. & 1 & 9 & $\wedge$ \\
\hline \multicolumn{4}{|c|}{ احتياجات خاصة بالتعامل مع أولياء أمور } & $\% 9$. & 1 & 9 & $r$ & \multicolumn{4}{|c|}{ احتياجات تدريسية } \\
\hline$\% 1 \ldots$ & . & 1. & 1 & $\% \wedge$. & r & $\wedge$ & $\leqslant$ & $\% q$. & 1 & 9 & 1 \\
\hline$\% \wedge$. & r & $\wedge$ & r & $\% 1 \ldots$ & . & 1. & • & $\% q$. & 1 & 9 & r \\
\hline$\% \wedge$. & r & $\wedge$ & $r$ & $\% 1 \ldots$ & . & 1. & 1 & $\% q$. & 1 & 9 & $r$ \\
\hline$\% 1 \ldots$ & . & 1. & 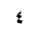 & $\% \wedge$. & r & $\wedge$ & v & $\% 1 \ldots$ & . & 1. & $\leqslant$ \\
\hline$\% 1 \ldots$ & . & 1. & • & $\% \wedge$. & r & $\wedge$ & $\wedge$ & $\% 1 \ldots$ & . & 1. & • \\
\hline$\% 1 \ldots$ & . & 1. & 1 & $\% \wedge$. & $r$ & $\wedge$ & 9 & $\% 1 \ldots$ & . & 1. & 7 \\
\hline & & & & $\% \wedge$. & r & $\wedge$ & 1. & $\% \wedge$. & $r$ & $\wedge$ & $v$ \\
\hline
\end{tabular}

يتضـح مـن جـدول رقم (1) أن نسـب اتفـاق السـادة أعضـاء هيئة التدريس بالجامعات علي كل عبارة من عبارات الاستبانة تتراوح ما بين:

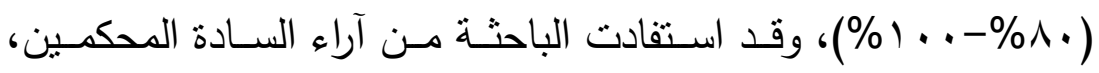
وتوجيهاتهم؛ من خلال مجموعة من الملاحظات،

\section{يمكن تلخيصها فيما يلي:--}

• تعديل صياغة بعض مفردات الاستبانة، وتتظيمها؛ لتصير أكثر دقة

$$
\text { ووضوحاً. }
$$

- إضافة بعض المفردات لبعض المحاو؛ لإثرائها. • حذف بعض المفردات؛ لعدم اتساقها مع محاورها. 
• إعادة النظر فى بعض المفردات التى تحمل أكثر من فكرة .

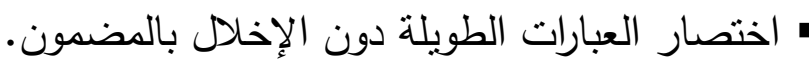
ثانياً: الصدق الذاتي حسبت الباحثة قيمة الصدق الذاتي الذي بساوي - حسابياً - الجذر

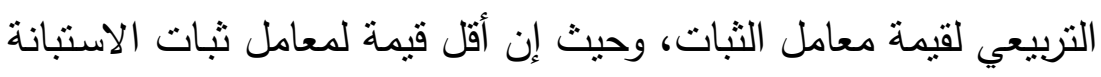

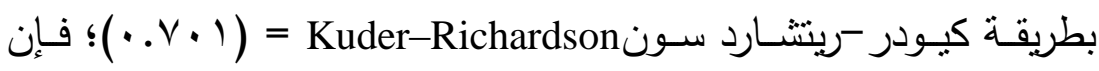

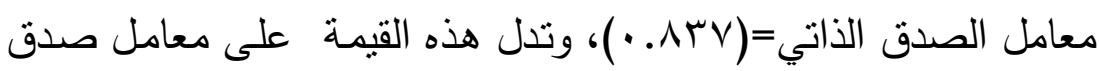

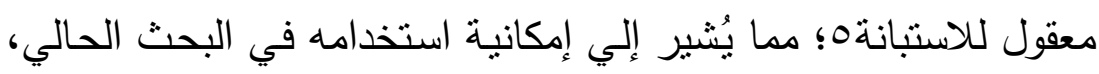
والوثوق في النتائج التي سيسفر عنها التطبيق. ثبات استبانة الاحتياجات التدريبية لمعلى الدمج بالمدارس الابتدائية حسبت الباحثة ثبات الاستبانة بطريقتين:

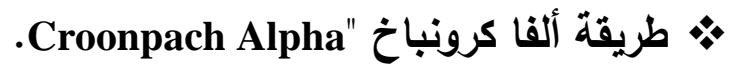

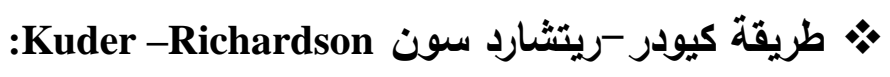
أولاً: حساب الثبات بطريقة ألفا كرونباخ "Croonpach Alpha": يوضـح جدول رقم (Y) معامـل الثبـات بطريقة "ألفـا كرونبـاخ" لكل عبارة، ومعامل الثبات الكلي لاستبانة الاحتياجات التدربية لمعلمى الدمج بالمدارس الابتدائية. 
جلول رقم (ץ): معامل الثبات بطريقة "ألفا كرونباخ" لكل عبارة، ومعامل الثبات الكلي لاستبانة

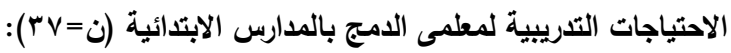

\begin{tabular}{|c|c|c|c|c|c|c|c|c|c|}
\hline معامل & 站 & الثبات & 蛋. & | معامل & 焉. & معامل & . & معامل & s. \\
\hline \multicolumn{2}{|c|}{ 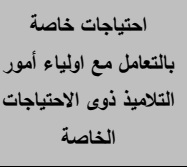 } & \multicolumn{2}{|c|}{ بعلية التقويم خاصة } & \multicolumn{2}{|c|}{ سيكولوجية وصفية } & \multicolumn{2}{|c|}{ احتياجات تدريسية } & \multicolumn{2}{|c|}{ الدتياجات عامة عن } \\
\hline . & 1 &. $.0 \wedge \wedge$ & 1 & .704 & 1 & $.0 \leqslant \mathrm{~V}$ & 1 &. $.7 \mathrm{NV}$ & 1 \\
\hline ..T: & $r$ & r & $r$ & .951 & $r$ & ..r.r & $r$ &. .790 & $r$ \\
\hline $.0 \wedge \mathrm{V}$ & $r$ & $\therefore \leqslant \mathrm{vo}$ & $r$ & ..ors & $r$ & דיד & $r$ &. .471 & $r$ \\
\hline $.0 \leqslant \wedge$ & $\varepsilon$ & .041 & 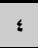 & ..Trr & $\varepsilon$ &. .099 & 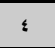 &. .010 & $\varepsilon$ \\
\hline .019 & . & & & .040 & - & .105 & - &. $.4 \mathrm{ro}$ & . \\
\hline \multirow[t]{7}{*}{. $.4 r$} & 7 & & &. $.7 v \varepsilon$ & 4 & זיז & 4 & $.1 \% 0$ & 1 \\
\hline & & & &. .999 & $\mathrm{v}$ &. $.14 \pi$ & $\mathrm{v}$ &. $.91 \mathrm{~V}$ & v \\
\hline & & & &. .4 .0 & $\wedge$ &. $.0 \vee \wedge$ & $\wedge$ &. .410 & $\wedge$ \\
\hline & & & & $.7 \% 1$ & 9 & .04r & 9 & & \\
\hline & & & &. $.0 \wedge \mathrm{V}$ & 1. &..$v .0$ & 1. & & \\
\hline & & & &. .701 & "1 & $.0 \mathrm{err}$ & "1 & & \\
\hline & & & & . Irv & ir & & & & \\
\hline$\cdot, \mathrm{v}, \mathrm{v}$ & \multicolumn{9}{|c|}{ معامل الثبات للاستبانة كلى } \\
\hline
\end{tabular}

إذا كان معامل الثبات بطريقة ألفا لكل عبارة من عبارات المقياس أقل من قيمة ألفا لمجموع عبارات المقياس ككل أسفل الجدول؛ فهذا يعني أن العبارة مهمة، وغيابها عن المقياس يؤثر سلباً فيه، وأما إذا كان معامل ثبات ألفا لكل عبارة أكبر من، أو يسـاوي قيمة ألفا للمقياس ككل أسفل

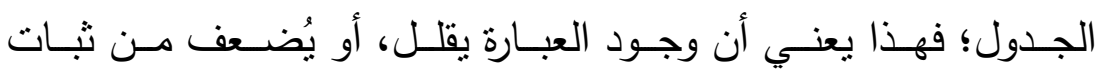

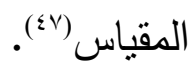

ومن الجدول السابق يتضح أن مفردات استبانة الاحتياجات التذريبية لمعلمى الدمج بالمدارس الابتدائية؛؛ يقل معامل ثباتها عن قيمـة معامل ثبات الاستبانة ككل؛ والذي بلغ (V • V. • )؛ وعليه ثتمتع الاستبانة بدرجة 
مرتقعة من الثبات؛ مما يشير إلى إمكانية استخدامها في البحث الحالي، والوثوق في النتائج التي سيسفر عنها البحث.

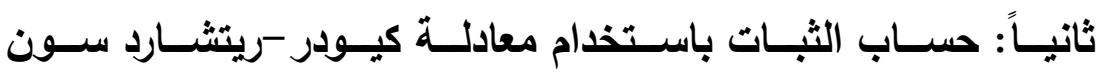
:Kuder -Richardson

حُسب ثبات استبانة الاحتياجـات التدريبية لمعلمى الدمج بالمدارس

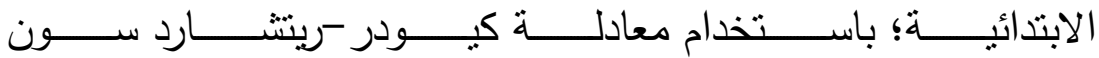
Kuder -Richardson هذه القيمة على أن الاستبانة تتمتع بقدر معقول من الثبات. الاستبانة في صورتها النهائية:

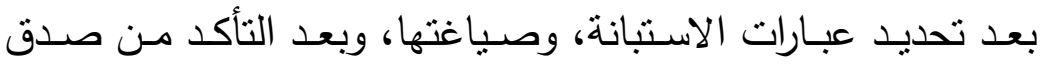
الاستبانة، وثباتها صارت - في صورته النهائية- صالحة للنطبيق، وقد

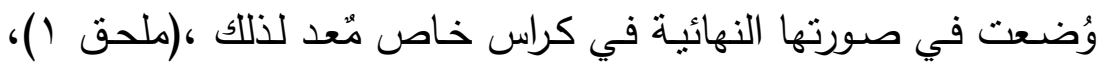
ويشمل الكراس:

صفحة الغـلاف، وتحتوي علـي (عنـوان الاسـتبانة، اسم الباحثنة،

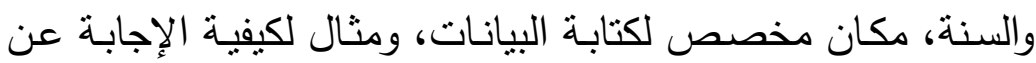
عبارات الاستبانة).

عبـارات البطاقـة ، وتبـدأ مـن (1) إلـى (1) (1) مقســة إلى خمســة محاور • نمان.

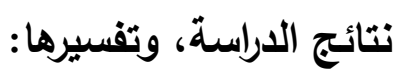
تستعرض الباحثة نتائج الدراسة الميدانية والتى تتضمن الاجابـة عن

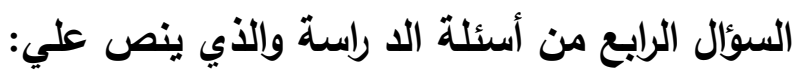

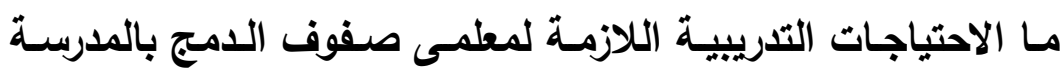
الابتدائية؟

تضـمنت اسـتبانة الاحتياجـات التدربييـة لمعلمسى صـفوف الـمـج خمسـة أنواع من الاحتباجات؛ قسمت على خمسة محاور كما يلي: 


$$
\text { • المحور الأول: احتياجات عامة عن الدمج التربوى. }
$$

" المحور الثالث: احتياجات سيكولوجية، وصفية.

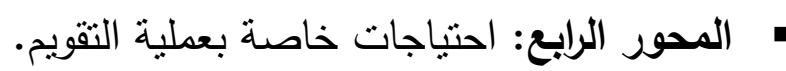

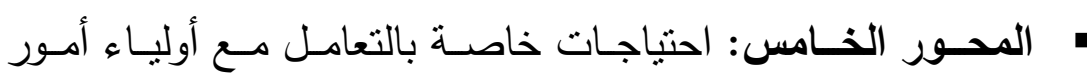

$$
\text { التلاميذ ذوى الاحتياجات الخاصة. }
$$

وبعد التأكد من صدق القائمة، وثباتها واتساقها من الناحية التركيبية،

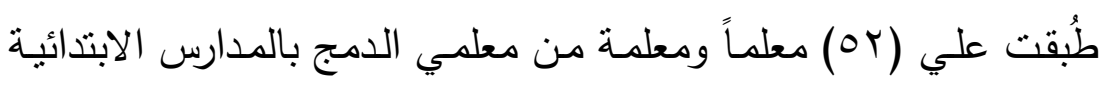

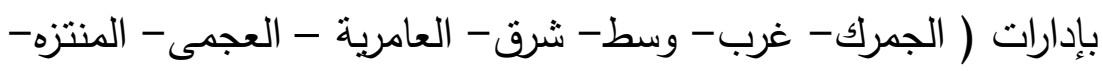
برج العرب) بمحافظة الإسكندرية، ثم حُسبت التكرارات، والنسب المئوبة،

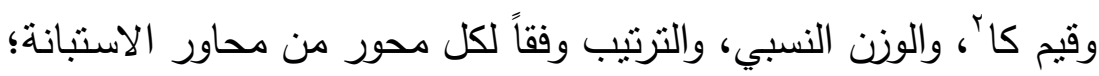
كما يلي:

بالنسبة للمحور الأول : احتياجات عامة عن الدمج التربوى:

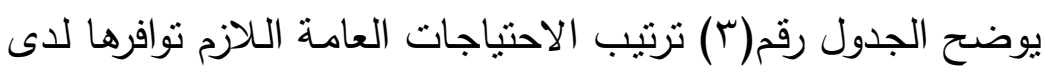

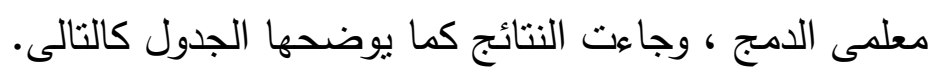


جدول رقم(r): التكرارات والنسب المئوية، وقيم كاب (*)والوزن النسبي وترتيب الاحتياجات العامة

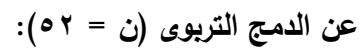

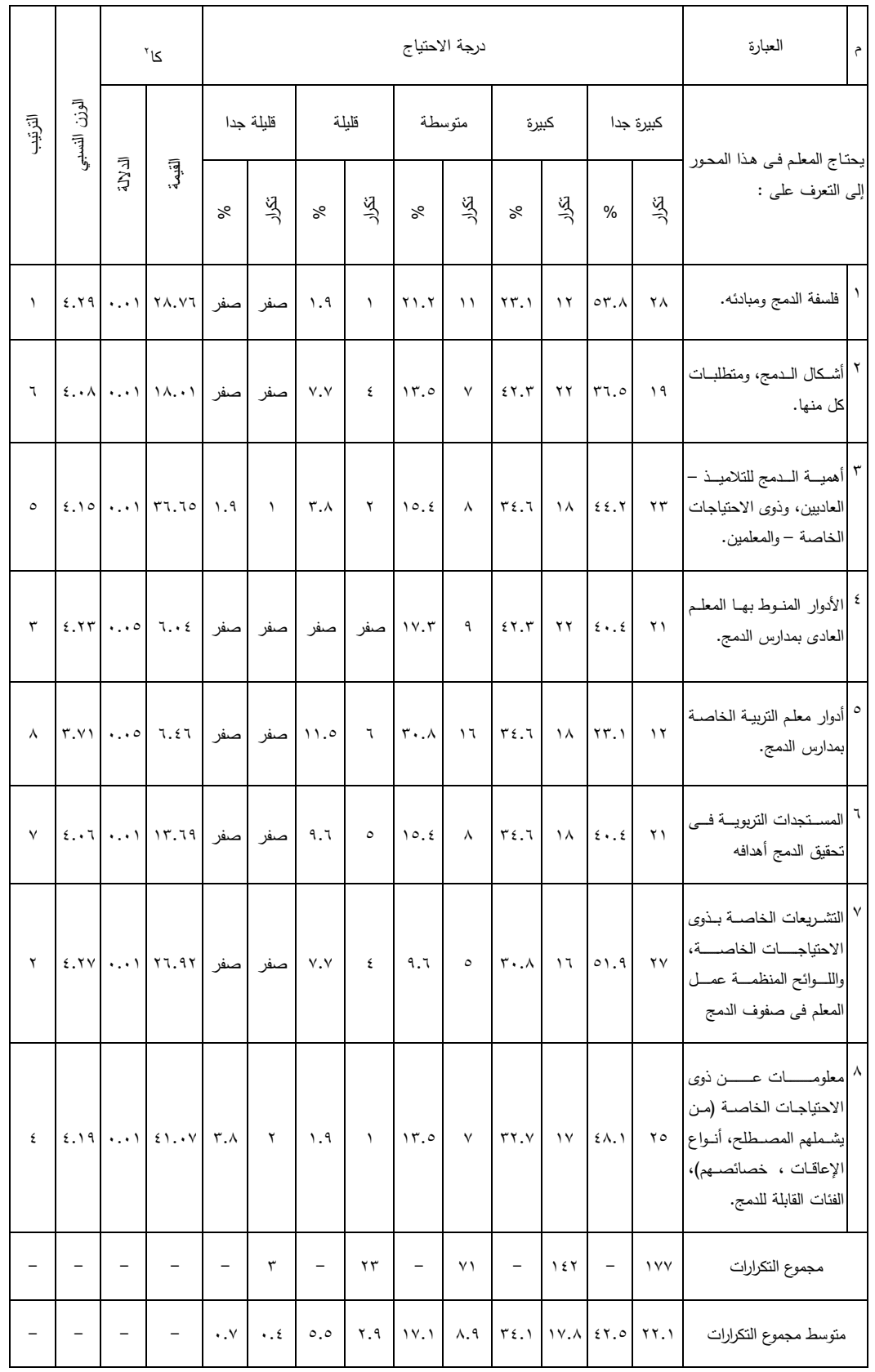

(*) ـ قيمة "كا " الجدولية عند مستوى دلالة (0 .. ) = 99.

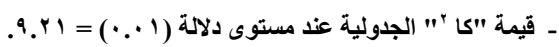


ويتضح من جدول رقم (r) أن جميع قيم كا` لعبارات المحور الأول

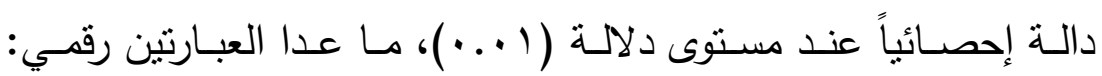

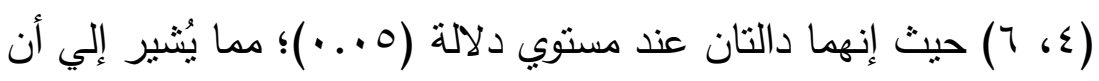

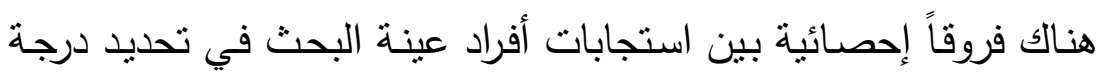

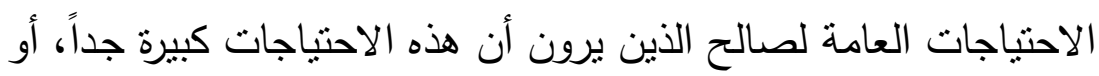

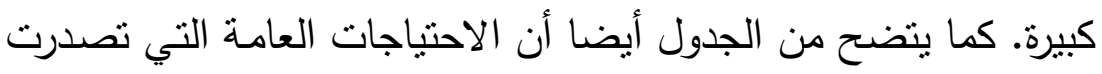
استجابات معلمي الدمج قد تضمنت حسب نرتيب هذه الاحتباجات طبقا

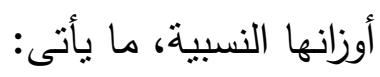

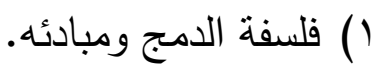

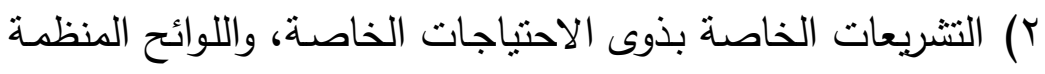
عمل المعلم فى صفوف الدمج. r) الأدوار المنوط بها المعلم العادى بمدارس الدمج.

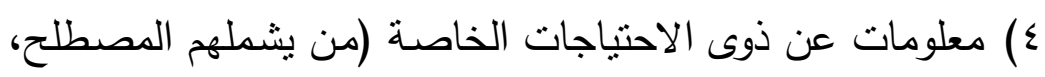

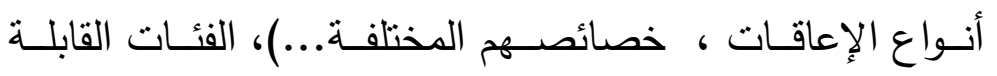
للامج. 0) أهميـة الدمج للتناميذ - العاديين وذوى الاحتياجـات الخاصـة والمعلمين.

7) أثكال الامج، ومتطلبات كل منها. ( المستجدات التربوية فى تحقيق الدمج أهدافه. ^) أدوار معلم التربية الخاصة بمدارس الدمج.

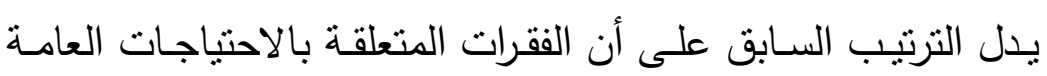

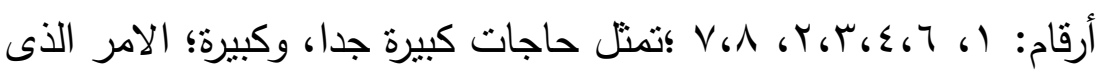
يدل على عدم تهيئة، ولا تأهيل المعلمين العاملين بصفوف الدمج ولاسيما

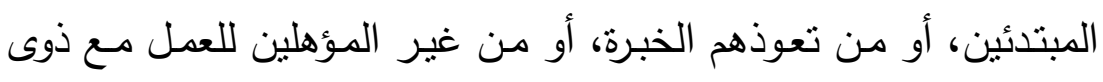


الاحتياجـات الخاصـة؛ بالمبـادئ الأساسـية لعمليـة الـدمج، والتشـريعات

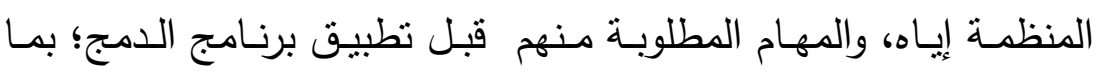

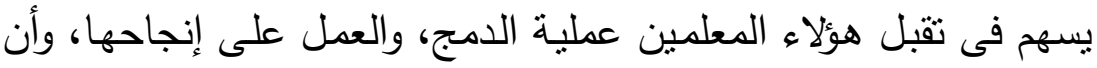

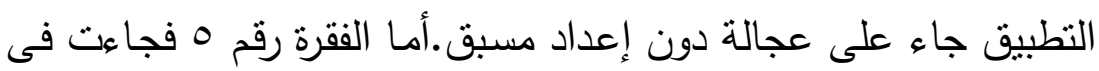

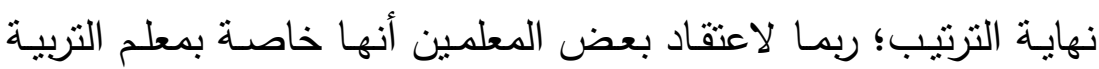
الخاصة؛؛ وليس من شأنهم • ويوضح شكل رقم (1) الأعمدة البيانية للنسب المئوية لتكرارات محور الاحتياجات الخاصة بالمعارف

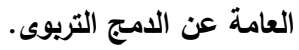

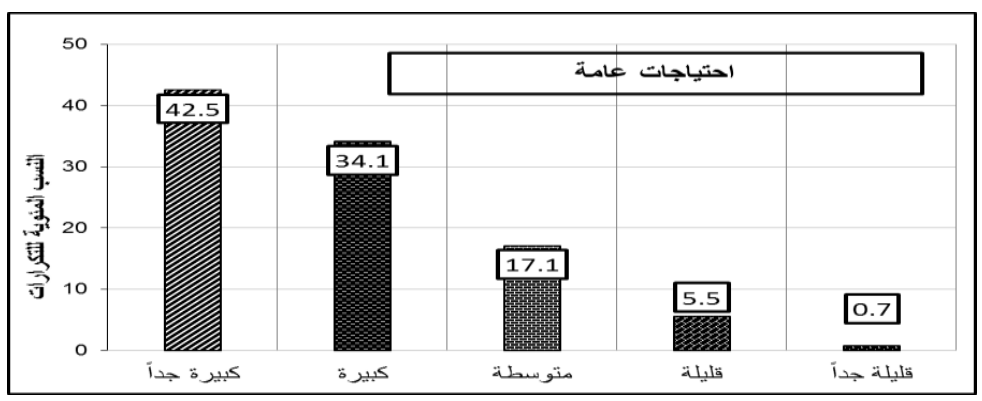

شكل رقم ( (1): الأعمدة البيانية للنسب المئوية لتكرارات الاحتياجات

الخاصة بالمعارف العامة.

وتتقق هذه النتائج مع دراسة "سوزان محمد أحمد السيد" (^ء)(التى أكدت بـات حاجة المعلمين إلى برنـامج تدريبى، يوضـح لهم فلسفة الدمج، ومبادئه

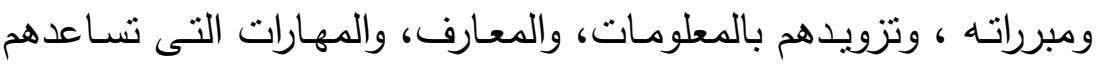

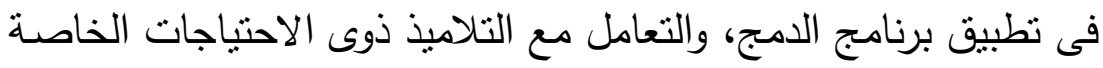
بخصائصهم المختلفة . ودراسة "أمير إبراهيم القرشي"(9 ؛) التى أكدت ضرورة تخطيط، وتتفيذ برامج تدريبية للمعلمين العاملين بصفوف الدمج؛ لتعريفهم بفلسفة الدمج، وأهميته بالنسبة لجميع التلاميذ ، وطبيعة الإعاقة، وخصـائص التلاميذ

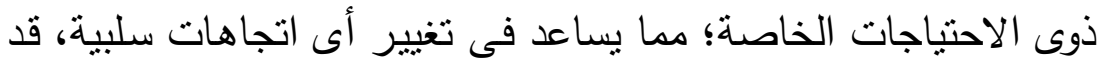

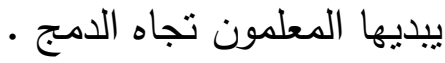


بالنسـبة للمحسور الثـاني:الاحتياجـات التدريسية: الـلازم توافرهـا لدى

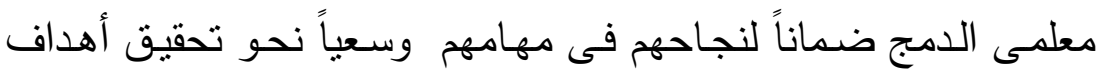

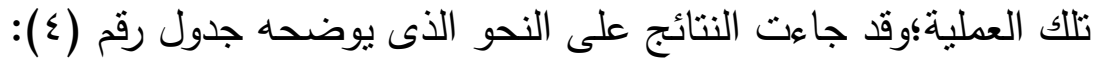
جدول رقم (ع) : التكرارات والنسب المئوية وقيم كاr (*) والوزن النسبي وترتيب الاحتياجات التدريسية (ن = rه)

\begin{tabular}{|c|c|c|c|c|c|c|c|c|c|c|c|c|c|c|c|}
\hline \multirow{3}{*}{ 雪 } & \multirow{3}{*}{$\begin{array}{l}\overline{7} \\
: \overline{3} \\
\overline{7}\end{array}$} & \multicolumn{2}{|r|}{ Sis } & \multirow{2}{*}{\multicolumn{2}{|c|}{ قليلة جدا }} & \multirow{2}{*}{\multicolumn{2}{|c|}{ قليلة }} & \multirow{2}{*}{\multicolumn{2}{|c|}{ متوسطة }} & \multirow{2}{*}{\multicolumn{2}{|c|}{ كبيرة }} & & & العبارة & ? \\
\hline & & 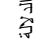 & 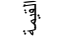 & & & & & & & & & \multicolumn{2}{|c|}{ كبيرة جدا } & \multirow{2}{*}{\multicolumn{2}{|c|}{ يحتاج المعلم فى هذا المحور إلى: }} \\
\hline & & & & ๙ & 望 & ๙ & 望 & ㅇ & 证 & ๙ & 羿 & & 望 & & \\
\hline r & โ.IV & $\ldots 1$ & $1 . . \leqslant r$ & صفر & صفر & صفر & صفر & 10.5 & $\wedge$ & 01.9 & rV & Tr.V & iv & 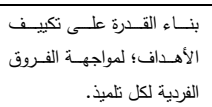 & 1 \\
\hline 1 & 5.19 & $\ldots 1$ & $\leqslant r .01$ & r.A & $r$ & 0.1 & $r$ & $v . v$ & $\varepsilon$ & $0 \ldots$ & ry & rT.V & iv & 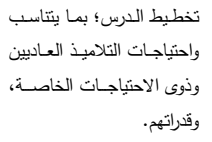 & r \\
\hline$r$ & $\varepsilon . . \varepsilon$ & $\ldots 1$ & $r \leqslant .0 \leqslant$ & 0.1 & $r$ & 1.9 & 1 & 15.0 & v & $\varepsilon \cdot . \varepsilon$ & rI & ru. 0 & $r$. & 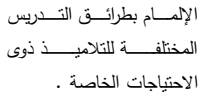 & $r$ \\
\hline 9.0 & T. . ६ & $\ldots 1$ & $11 . .1$ & r.A & r & صفر & صفر & $r . r$ & 11 & $\leq \varepsilon . Y$ & rr & $r \cdot . \wedge$ & 17 & 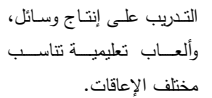 & $\varepsilon$ \\
\hline 9.0 & r.q६ & $\ldots 1$ & $0 . . r 1$ & r.A & r & 1.9 & 1 & $1 T .0$ & v & 00.1 & rq & ro. & it & 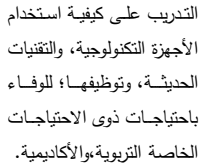 & 。 \\
\hline 0.0 & ... & $\ldots 1$ & rA.. & 1.9 & 1 & r.A & r & W.r & 9 & 纟A. 1 & ro & 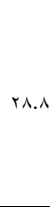 & 10 & 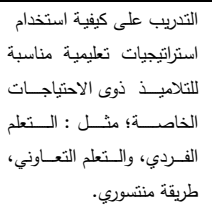 & 7 \\
\hline V.o & $r .91$ & $\ldots 1$ & rr. 97 & V.V & $\varepsilon$ & 1.9 & 1 & 11.0 & 7 & $\varepsilon \cdot . \leqslant$ & r) & rN. . & $r$. & 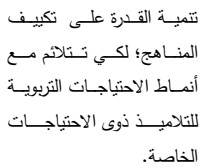 & v \\
\hline 0.0 & $\{. .1$ & $\cdots+1$ & $9 . r 9$ & V.V & $\varepsilon$ & صفر & صفر & ro.. & 15 & r..V & IV & $r \leqslant . T$ & 11 & 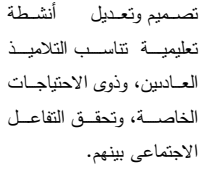 & $\wedge$ \\
\hline
\end{tabular}

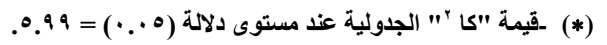

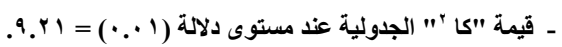

rot 


\begin{tabular}{|c|c|c|c|c|c|c|c|c|c|c|c|c|c|c|c|}
\hline v.o & r.9A & $\ldots 1$ & r9.9r & 0.1 & r & 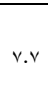 & $\varepsilon$ & 9.7 & 。 & $\varepsilon \ldots \varepsilon$ & r & 97.0 & 19 & 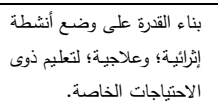 & a \\
\hline$\varepsilon$ & \&.. & $\ldots$ & $r . . r q$ & 1.9 & , & صفر & صفر & $r . r$ & "1 & $r . . \wedge$ & 17 & \&4. & $r \xi$ & 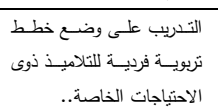 & 1. \\
\hline " & r.AY & $\ldots$ & $r . . r$ & r. & r & صفر & صفر & iv.r & a & 00.1 & rq & $r+1$ & ir & 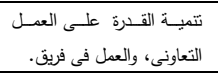 & " \\
\hline - & - & - & - & - & riv & - & $1:$ & - & 9^ & - & TrY & - & rir & \multicolumn{2}{|c|}{ يجموع النكرارات } \\
\hline - & - & - & - & $\varepsilon . r$ & r.r & $r . r$ & i.1 & $10 . \mathrm{V}$ & A.r & \&r.A & $r r . T$ & $r \leqslant .$. & IV.Y & \multicolumn{2}{|c|}{ متوسط مجموع النكرارات } \\
\hline
\end{tabular}

يتضح من جدول رقم (ع) أن جميع قيم كا' لعبارات المحور الثاني

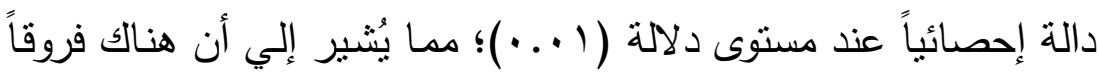
إحصائية بين استجابات أفراد عينة البحث في تحديد درجة الاحتياجات

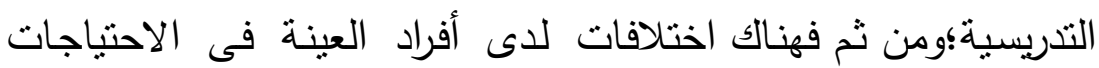
التدريسية؛ لصالح الذين يرون أن هذه الاحتياجات كبيرة جداً، أو كبيرة .

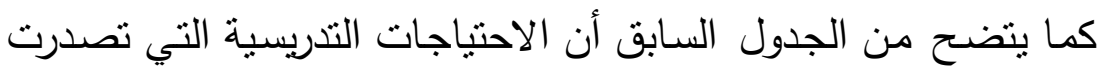
استجابات معلمي الدمج قد تضمنت - حسب ترتيب هذه الاحتياجات

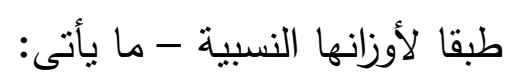
() تخطيط الدرس؛ بمـا يتتاسـب واحتياجـات التلاميذ العـاديين، وذوى لوانى الاحتياجات الخاصة، وقدراتهم. r) بناء القدرة على تكييف الأهداف؛ لمواجهة الفروق الفردية لكل تلميذ.

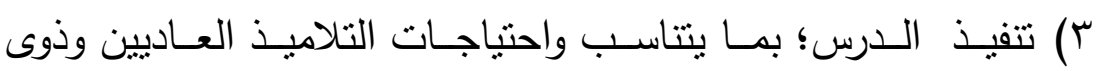
الاحتياجات الخاصة، وقدراتهم.

ع) الإلمام بطرائق التدريس المحتلفة للتلاميذ ذوى الاحتياجات الخاصة . 0) ولقد حصل الاحتياجان الآتيان علي نفس الرنبة؛ وهما:

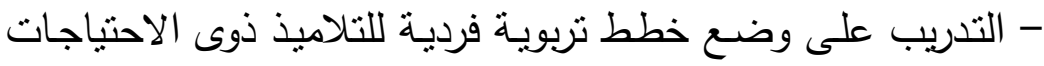

\section{الخاصة}

- التدريب على كيفية استخدام استراتيجيات تعليمية مناسبة للتلاميذ

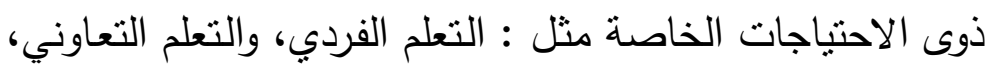
وطريقة منتسوري. 
7) وحصلت الاحتباجات الآتية علي نفس الرتبة؛ من حيث الأهمية:

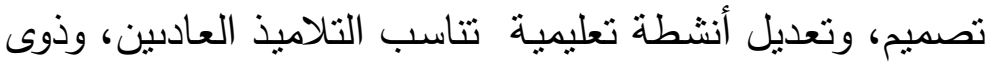
الاحتياجات الخاصة، وتحقق التفاعل الاجتماعى بينهم.

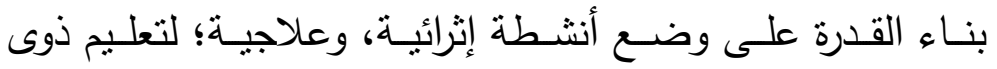
الاحتياجات الخاصة.

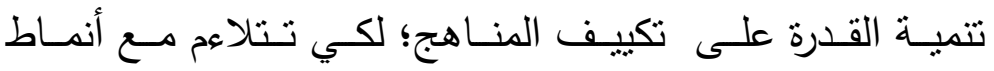
الاحتياجات التربوية للتلاميذ ذوى الاحتياجات الخاصة. V وحصلت الاحتباجات الآتية علي نفس الرتبة؛ وهى: ولئ

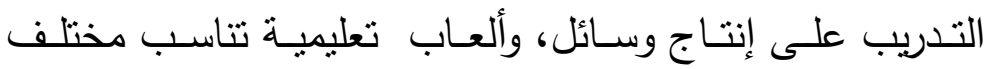
الإعاقات.

التـدريب على كيفيـة اسـتخدام الأجهـزة التكنولوجيـة، والتقنيـات

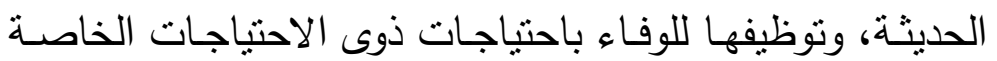
التربوية ،والأكاديمية.

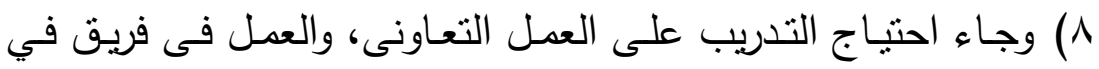
المرتبة الأخيرة في استجابات عينة البحث. ويدل هذا الترتيب للأهداف -كما يدركه أفراد عينة البحث - على على لينه

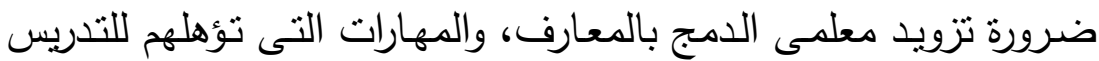
للتلاميذ ذوى الاحتياجات الخاصة، و بما يلبى احتياجات هؤلاء التلاميذ؛

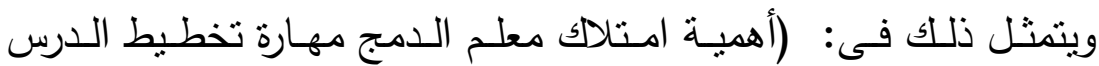
وتطويـع الأهداف ، والقدرة على تتفيذ الدرس؛ يمـا يـتلاعم مـع قدرات التلاميذ ذوى الاحتياجات الخاصة ، والإلمام بطرائق التدريس المختلفة ،

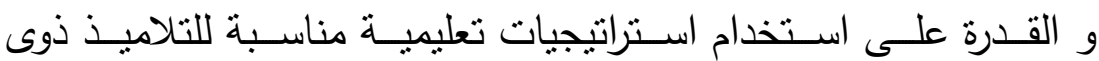
الاحتياجات الخاصة ، ووضع خطط تربوية فردية لهم ). 
وقد جاءت الاحتياجـات المتعلقة (بتصميم، وتعديل أنشطة تعليميـة

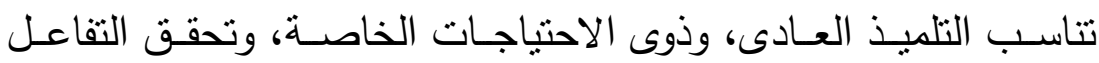
الاجتمـاعى بينهم، و بنـاء القدرة على وضـع أنشطة إثرائيـة، وعلاجيـة؛

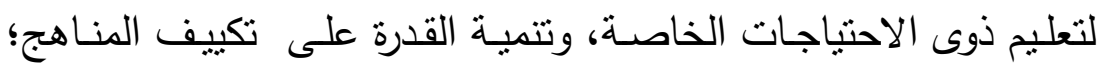

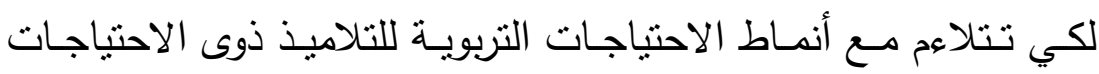

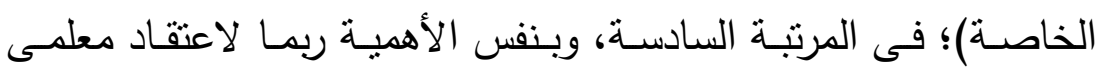

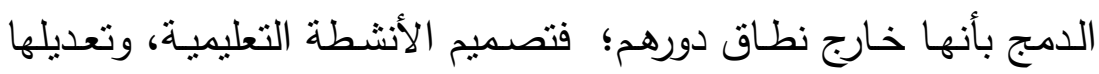

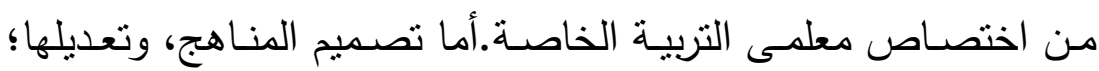
فيتم من قبل وزارة التربية والتعليم •

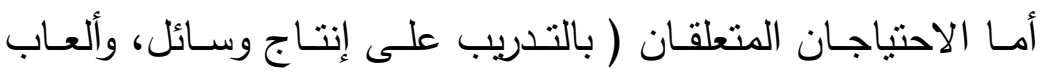
تعليميـة تتاسب مختلف الإعاقـات؛ للوفاء باحتياجـات ذوى الاحتياجـات

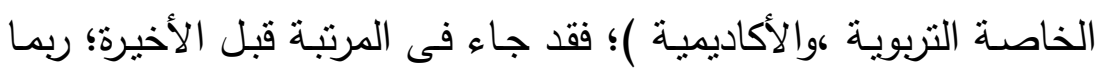

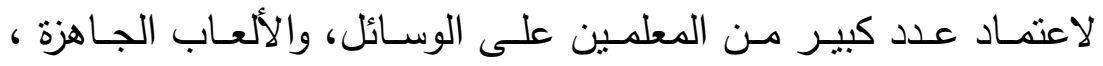

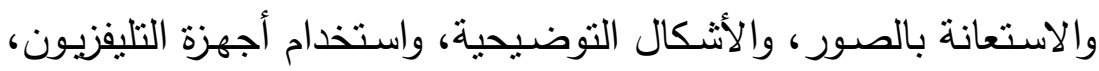

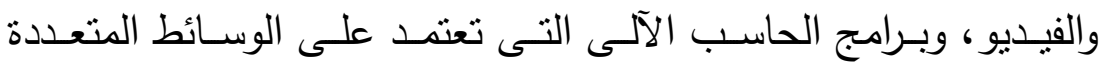

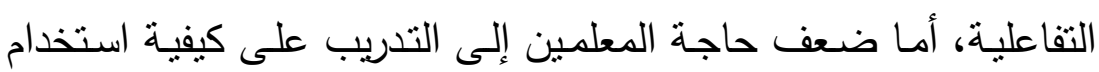
الأجهزة التكنولوجية، والتقنيات الحديثة، وتوظيفها؛ فيرجع إلى أن معظم النه

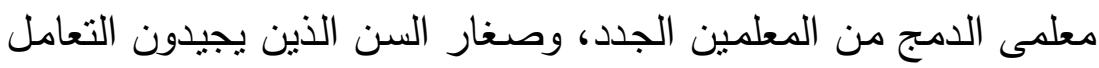

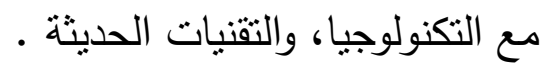

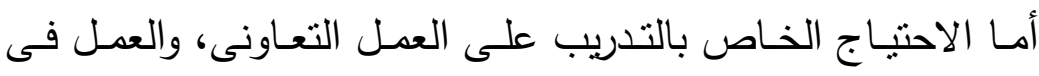

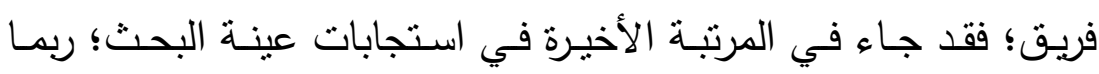

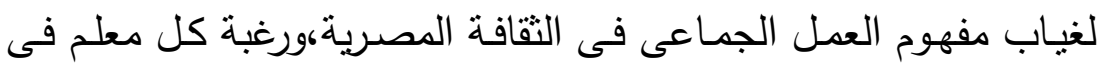

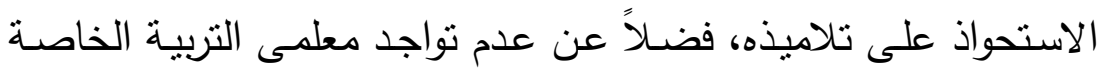

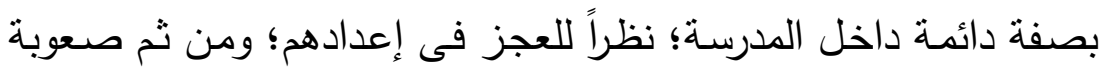
التتسيق بينهم للعمل الجماعى. 
ويوضح شكل رقم (r) الأعمدة البيانية للنسب المئوية لتكرارات محور

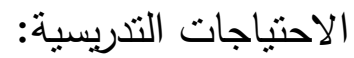

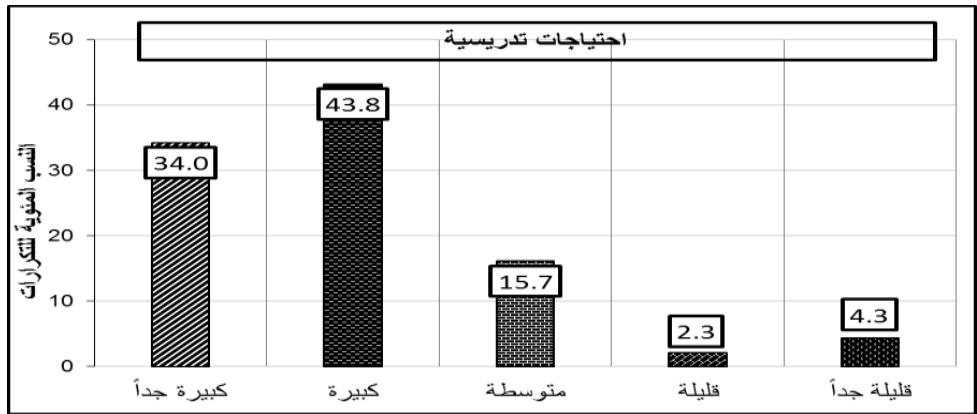

شكل رقم (ץ): الأعمدة البيانية للنسب المئوية لتكرارات محور الاحتياجات التريسية

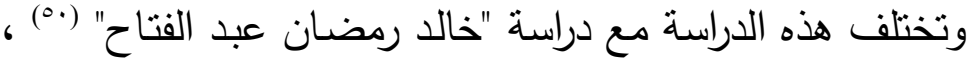

التى أكدت أهمية تدريب معلمى الدمج على تعديل المناهج ، والوسائل

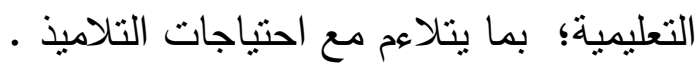

\section{المحسور الثالـث : ويـدور حسول الاحتياجـات سـيكولوجية، وصـفية :}

والذى كانت نتائجه كما يوضحها الجدول رقم (0) على النحو التالى. 


\begin{tabular}{|c|c|c|c|c|c|c|c|c|c|c|c|c|c|c|c|}
\hline \multirow{3}{*}{ 高 } & \multirow{3}{*}{$\begin{array}{l}\overline{3} \\
\overline{3} \\
\overline{7}\end{array}$} & \multicolumn{2}{|c|}{ Sו } & \multicolumn{10}{|c|}{ درجة الاحتباج } & 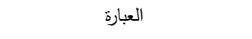 & s \\
\hline & & \multirow{2}{*}{ 交 } & \multirow{2}{*}{ 守 } & \multicolumn{2}{|c|}{ قللية جدا } & \multicolumn{2}{|c|}{ قليلة } & \multicolumn{2}{|c|}{ متوسطة } & \multicolumn{2}{|c|}{ كبيرة } & \multicolumn{2}{|c|}{ كبيرة جدا } & \multirow{2}{*}{\multicolumn{2}{|c|}{ يحتاج الدعلم فى هذا الدحور إلى: }} \\
\hline & & & & $\stackrel{\circ}{\circ}$ & 照 & $\circ$ & 望 & $\therefore$ & 照 & $\therefore$ & 望 & $\%$ & 望 & & \\
\hline 1 & E.r9 & $\cdots 1$ & $19 . r 5$ & صفر & صفر & r.A & r & iv.r & 9 & $r \mu_{.0}$ & r. & $\varepsilon \cdot . \varepsilon$ & $r$ & 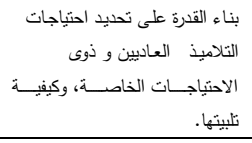 & 1 \\
\hline$\wedge$ & ¿.1T & $\cdots 1$ & 18.79 & صفر & صفر & 1.9 & 1 & rr. & ir & r7.0 & 19 & $r_{\lambda .0}$ & r. & 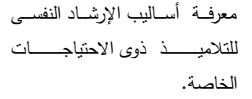 & r \\
\hline "1 & $\varepsilon . . \varepsilon$ & $\cdots 1$ & 7.71 & صفر & صفر & صفر & صفر & $r+1$ & ir & 0. & rq & $r 4.9$ & $1 \leqslant$ & 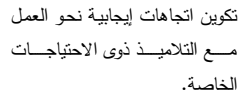 & $r$ \\
\hline v & $\varepsilon .1 \%$ & $\cdots 1$ & rr.qr & صفر & صفر & 0.1 & r & 11.0 & 1 & \& & rr & $r_{\lambda .0}$ & r. & 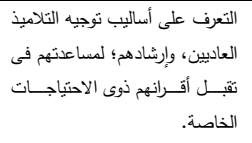 & $\varepsilon$ \\
\hline 9.0 & $\{. .4$ & $\cdots 1$ & r... & صفر & صفر & r.A & r & 11.0 & 1 & $0 \ldots$ & rq & $r \leqslant .7$ & 11 & الامتج الاحتياجـات الخاصـة لبرنامج & $\circ$ \\
\hline «. & $\$ 10$ & $\ldots 1$ & $r \varepsilon . T r$ & 1.9 & 1 & صفر & صفر & iv.r & 9 & r..V & iv & $\{\Lambda .1$ & ro & 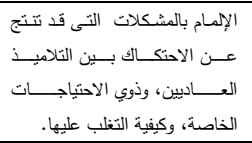 & 7 \\
\hline ๕.० & $\{.10$ & $\ldots 1$ & YX.YY & صفر & صفر & 1.9 & 1 & 11.0 & 1 & sr.r & rr & $\varepsilon$ ¿.r & rr & 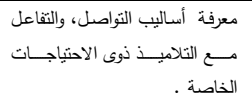 & v \\
\hline ๕.० & $\leq .10$ & $\ldots 1$ & Ir.vV & صفر & صفر & 0.1 & $r$ & $r+1$ & ir & $r \wedge .0$ & r. & rY.V & iv & 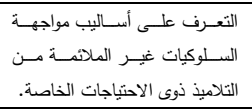 & $\wedge$ \\
\hline ..० & $\{.10$ & $\ldots 1$ & $01 . \wedge \varepsilon$ & 1.9 & 1 & 1.9 & 1 & 9.7 & $\circ$ & 01.9 & $r v$ & $r \leqslant .7$ & 11 & 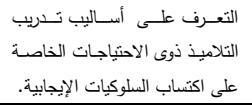 & 9 \\
\hline 9.0 & $\{. .4$ & $\cdots 1$ & $10 . \mathrm{TV}$ & صفر & صفر & صفر & صفر & 11.0 & 1 & 00.1 & rq & r..V & iv & 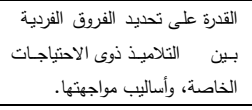 & 1. \\
\hline r & \&.r & $\ldots 1$ & rr.os & صفر & صفر & 1.9 & 1 & IV.r & 9 & & $r \varepsilon$ & $r \leqslant .4$ & 11 & 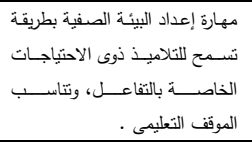 & 11 \\
\hline ir & r.91 & $\ldots 1$ & r.T. & صفر & صفر & r.A & r & 10.4 & $\wedge$ & 01.9 & rV & YA.A & 10 & 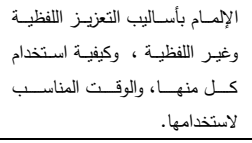 & ir \\
\hline- & - & - & - & - & r & - & 17 & - & $1 .$. & - & rvq & - & rtr & مجموع التكرارات & \\
\hline - & - & - & - &.$r$ &..$r$ & r.T & $1 . r$ & 17.1 & A.r & «..V & re.r & r.. & 11.9 & متوسط مجموع النكرارات & \\
\hline
\end{tabular}


إحصائية بين استجابات أفراد عينة البحث في تحديد درجة الاحتياجات

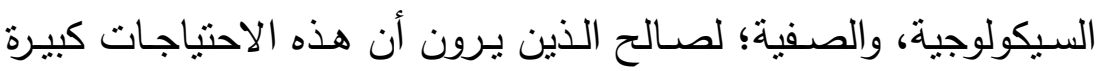

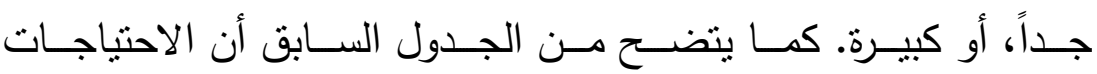

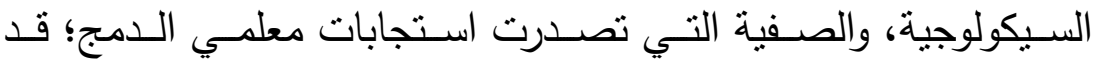

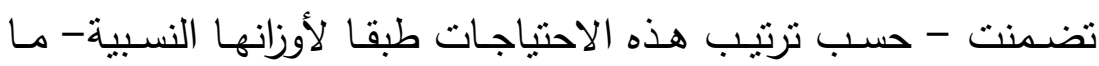
يأتى :

( ) بناء القدرة على تحديد احتياجات التلاميذ العاديين وذوي الاحتياجات الخاصة وكيفية تلبيتها.

r) مهارة إعداد البيئة الصفية بطريقة تسمح للتلاميذ ذوى الاحتياجات الخاصة بالتفاعل، وتتاسب الموقف التعليمى. r) وحصلت الاحتياجات الآتية علي نفس الرتبة؛ وهى:

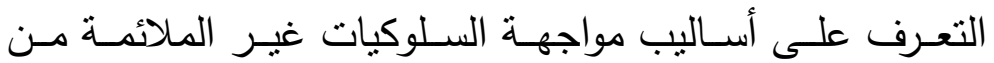
التلاميذ ذوى الاحتباجات الخاصة . التعرف على أسـاليب تدريب التلاميذ ذوى الاحتياجات الخاصـة على اكتساب السلوكيات الإيجابية. التعرف على المشكلات التى قد تتتج عن الاحتكالك بين التلاميذ التيذ التئ العاديين؛ وذوي الاحتياجات الخاصة، وكيفية التخلب عليها. معرفة أساليب التواصل، والتفاعل مـع التناميذ ذوى الاحتياجات

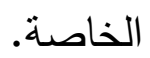

ع) معرفة أساليب الإرشاد النفسي للتلاميذ ذوى الاحتياجات الخاصة .

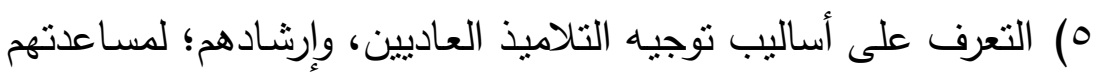
فى تقبل أقرانهم ذوى الاحتياجات الخاصة. 7) وحصل الاحتياجان الآتيان علي نفس الرتبة؛ وهما: 
القدرة على تحديد الفروق الفرديـة بين التلاميذ ذوى الاحتياجات

الخاصة، وأساليب مواجهتها.

هالتعرف على أسـاليب تهيئة التلاميذ ذوى الاحتياجـات الخاصـة

$$
\text { لبرنامج الدمج. }
$$

( ) ثم الاحتياج الخاص بتكوين اتجاهات إيجابية نحو العمل مع التلاميذ

$$
\text { ذوى الاحتياجات. }
$$

^) وأخيراً الاحتياج الخاص التعرف على أساليب التعزيز اللفظية، وغير اللفظية، وكيفية استخدام كل منها، والوقت المناسب لاستخدامها.

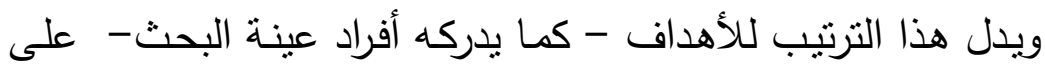

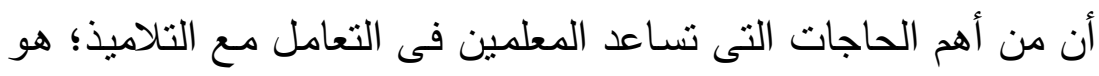

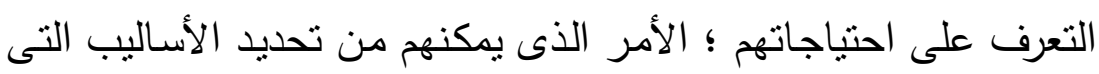

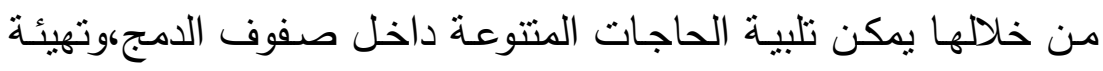

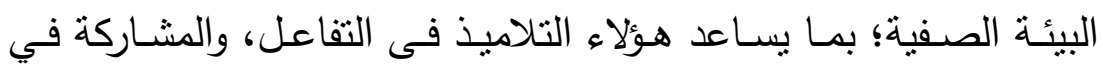
الأنشطة التعليمية إلي أقصي حد مدكن؛ وهو الاحتياج الذى جاء فى هولى لئه المرتبة الثنانية. وقد تلى ذلك الاحتياجات الخاصة ( بأساليب مواجهة السلوكيات غير

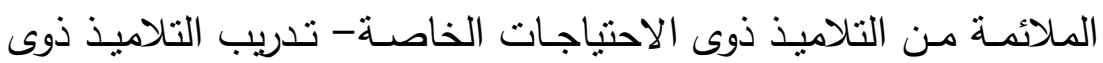

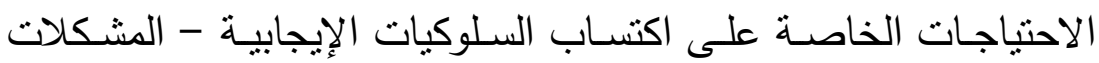
التى قد تتنج عن الاحتكاك بين التلاميذ العـاديين، وذوبي الاحتياجات

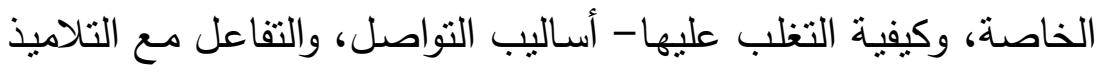
ذوى الاحتياجات الخاصـة)؛ ويرجع ذلك إلى اقتتاع المعلمين بأن أكثر لئر عملية معقدة يمكن أن تواجهه في صفوف الدمج هي تلك التي تتعلق

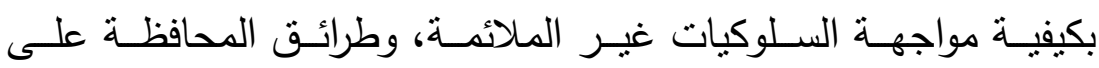
السـلوكيات الملائمـة، والأسـاليب التي يجب علبـ على المعلمين إتباعها في التعامل مع السلوك غير الملائم ، ويعدون ذلك جزءا أساسيا من مهامهم. 
أما الاحتياجات الخاصة (بالإرشاد النفسي للأطفال ذوى الاحتياجات

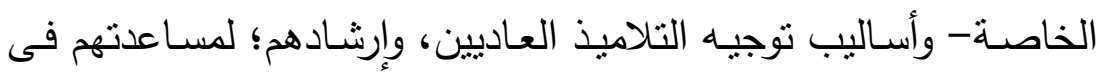

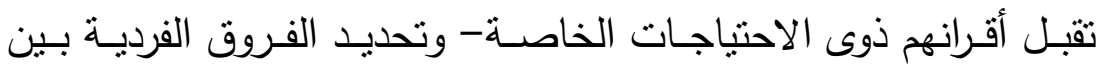
التلاميـذ ذوى الاحتياجـات الخاصـة، و التعـرف على أسـاليب تهيأئنهم

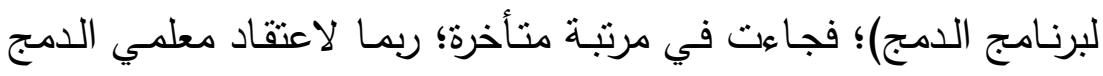

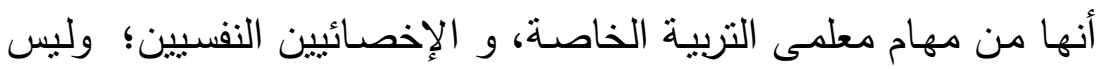

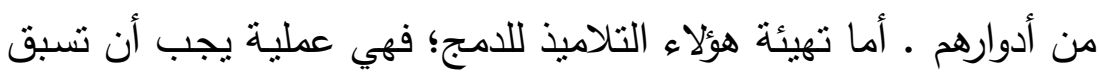

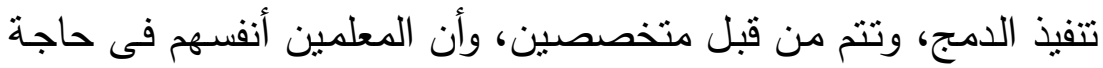

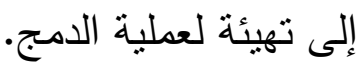
وقد جاء الاحتياج الخاص بتكوين اتجاهات إيجابية نحو العمل مـع التلاميذ ذوى الاحتباجات؛ فى المرتبة قبل الأخيرة ربما لاعتقاد المعلمين

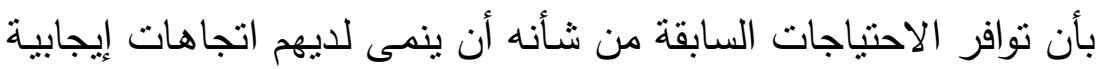

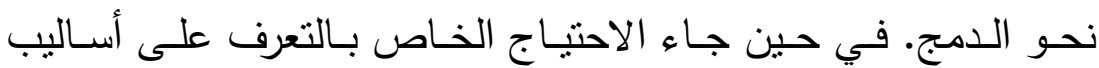
التعزيـز اللفظيـة، وغيـر اللفظيـة، وكيفيـة اسـتخدام كل منهـا، والوقت

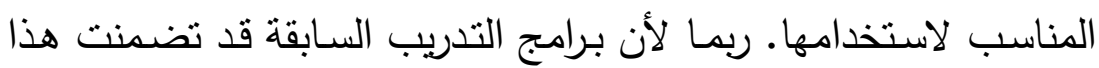

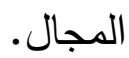
ويوضح شكل رقم (ץ): الأعمدة البيانية للنسب المئوية لتكرارات محور الاحتياجات السيكولوجية، والصفية.

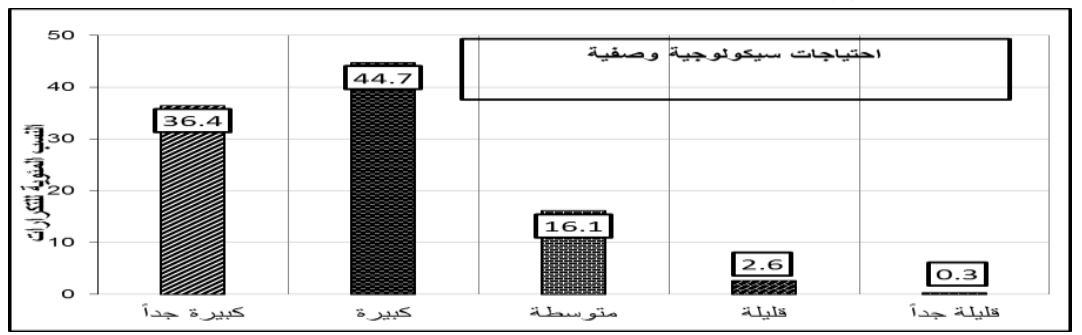

شكل رقم (ץ): الأعدة البيانية للنسب المئوية لنكرارات محور الاحتياجات النيكولوجية، والصفية.

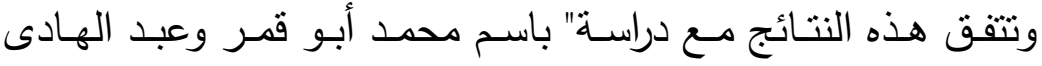
حمدان"(1) التى أكدت على ضرورة تدريب المعلمين فى المدارس العادية على أساليب التعامل مع التلاميذ المدمجين فى مدارسهر. 
كما تتفق مـع دراسـة " راندا مصطفى الديب"((هr) التى توصلت إلى

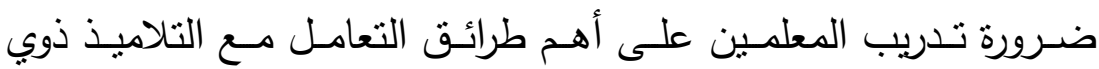

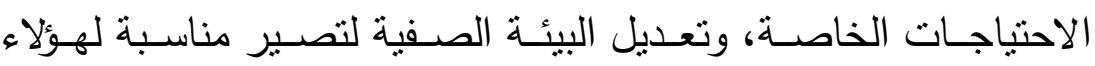
التلاميذ؛ مما يزيد من المهارات الاجتماعية لديهم. بالنسبة للمحور الرابع : احتياجات خاصة بعملية التقويم :

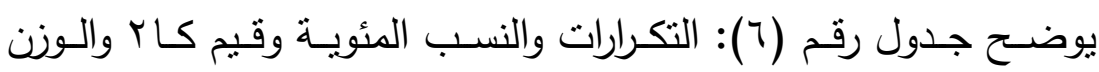
النسبي وترتيب الاحتياجات التي تتعلق بعملية التقويم.

جدول رقم(؟): التكرارات والنسب المئوية وقيم كاr (*) والوزن النسبي وترتيب الاحتياجات التي

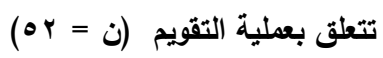

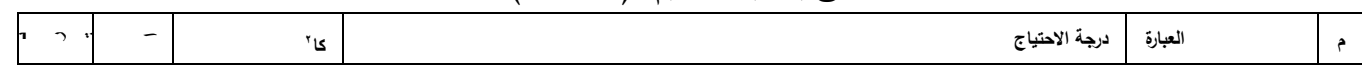


تصور مقترح لبرنامج تدريبي لمعلمي الدمج فى المدرسة الابتائية فى ضوء احتياجاتهم د.هيام عب الرحيم أحد

\begin{tabular}{|c|c|c|c|c|c|c|c|c|c|c|c|c|c|c|c|}
\hline & & 高 & 覃 & \multicolumn{2}{|c|}{ قليلة جا } & & قليلة & \multicolumn{2}{|c|}{ متوسطة } & \multicolumn{2}{|r|}{ كبيرة } & \multicolumn{2}{|c|}{ كبيرة جدا } & \multirow{2}{*}{\multicolumn{2}{|c|}{ إلى : يحتاج المطم فى هذا المحور }} \\
\hline & & & & $\therefore$ & 翠 & $\therefore$ & 照 & ஃ & 翠 & $\therefore$ & 照 & $\%$ & 瓷 & & \\
\hline r & $\{. .1$ & $\ldots 1$ & $\$ 4.10$ & 1.9 & ' & 0.1 & $r$ & 11.0 & ' & 01.9 & rv & r..A & 10 & 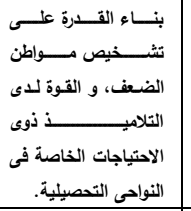 & 1 \\
\hline$r$ & $r .99$ & $\ldots 1$ & $r v . \& r$ & $r . \Lambda$ & $r$ & 0.1 & $r$ & 11.0 & 4 & $\{\wedge .1$ & ro & 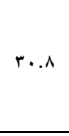 & 14 & 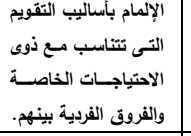 & r \\
\hline 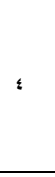 & r.1. & $\ldots 1$ & $m .40$ & 0.1 & $r$ & r.A & $r$ & 10.8 & $\wedge$ & $\circ$. & m & ro & ir & 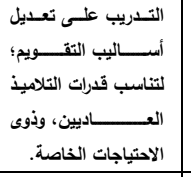 & $r$ \\
\hline 1 & $\{. .4$ & $\ldots 1$ & $\$ 1.44$ & 0.1 & $r$ & 1.9 & ' & 9.9 & 。 & 54.4 & rs & m.0 & 19 & 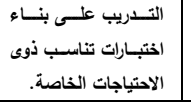 & $\xi$ \\
\hline- & - & - & - & - & a & - & a & - & ro & - & $1 . r$ & - & $i$ & لوع التكرارات & \\
\hline - & - & - & - & ¿.r & r.r & ¿.r & r.r & ir & r.r & $\leqslant 9 .$. & ro.e & $r . . r$ & 10.1 & متوسط مجموع الككرارات & \\
\hline
\end{tabular}

ويتضح من جدول رقم (T) أن جميع قيم كا' لعبارات المحور الرابع

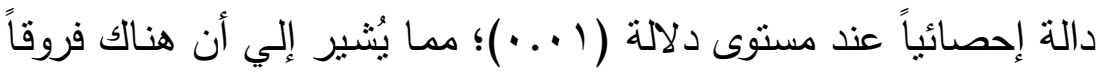

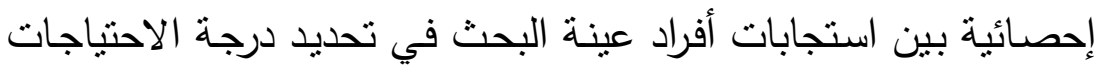

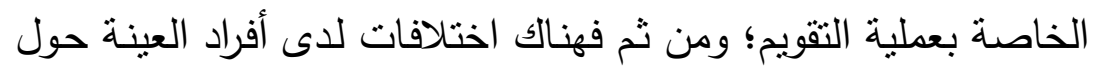

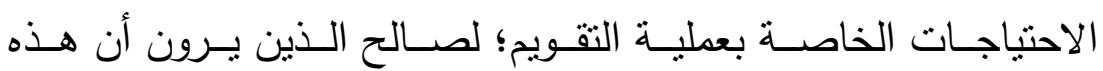

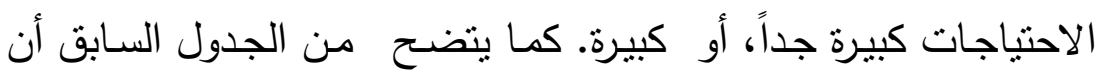
الاحتياجات الخاصـة بعملية التقويم؛ والتي تصدرت استجابات معلمي

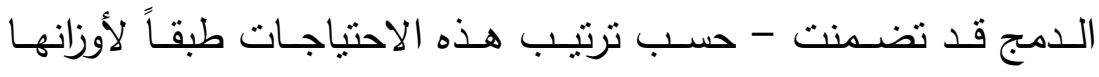

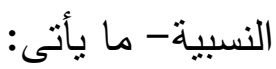

( ) التدريب على بناء اختبارات تتاسب ذوى الاحتياجات الخاصة.

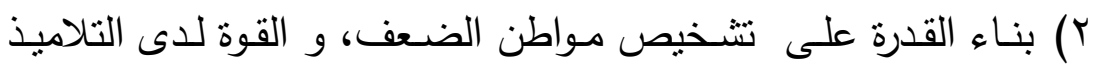
ذوى الاحتياجات الخاصة فى النواحى التحصيلية. 
r) الإلمام بأساليب التقويم التى تتتاسب مع ذوى الاحتياجات الخاصـة، والفروق الفردية بينهم.

ع) وجاء احتياج التدريب على تعديل أسـاليب التقويم؛ لتتاسب قدرات

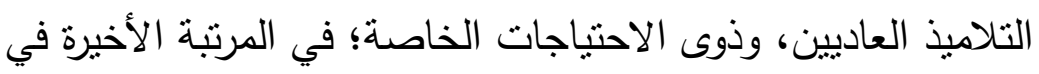

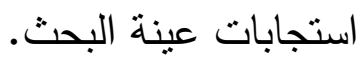

ويدل هذا الترتيب للأهداف - كمـا يدركه أفراد عينـة البحثـ-

على أهمية حاجة معلمى الدمج إلى التدريب على بناء اختبارات؛ لقياس

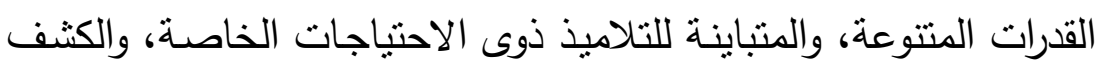
عن مـواطن القوة، والضـعف لديهم فى النواحى التحصيلية ، والإلمـام

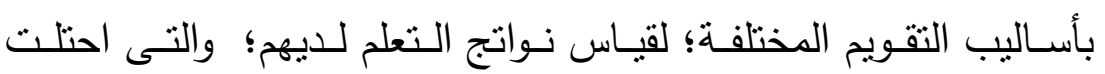
المراتب الثلاثة الأولى؛ نظراً لعدم تضدنها فى برامج إعدادهم ، فى حين لهن

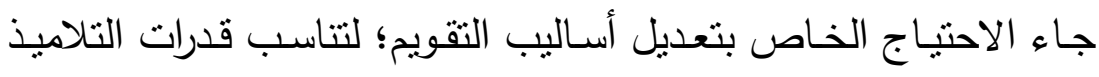
العاديين، وذوى الاحتياجات الخاصـة؛ فى المرنبة الرابعة والأخيرة؛ ربما

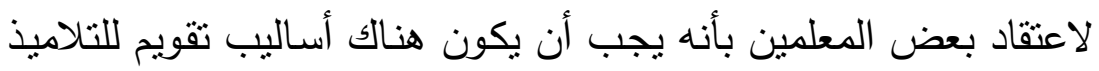

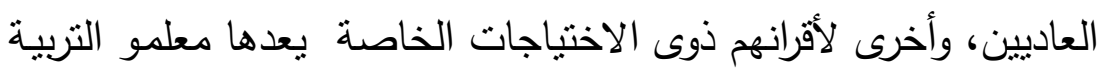
الخاصة .

ويوضح شكل رقم (ع) الأعمدة البيانية للنسب المئوية لتكرارات محور احتباجات خاصة بعملية التقويم:

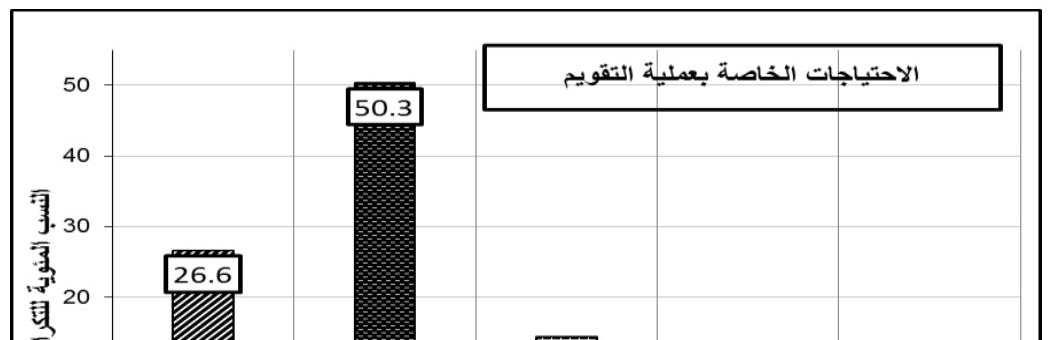


شكل رقم(؛): الأعمدة البيانية للنسب المئوية لتكرارات الاحتياجات الخاصة بعملية الامج التربوى

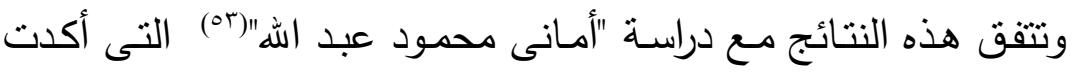
ضـرورة تدريب المعلمين على استخدام أدوات القيـاس النفسي، والتقويم التزبوي؛ حتى يتمكنوا من تقييم التلاميذ ذوى الاحتياجات الخاصة . بينما تختلف مـع دراسـة " خالد رمضـان عبد الفتاح سليمان" (\&) التى أكـدت أهميـة تـدريب معلـم الـدمج على تعـديل أسـاليب التقويم، والاختبارات؛ بما بناسب مستوبات التلاميذ العاديين، وذوى الاحتياجات الخاصة، وقدراتهم. المحـور الخـامس: الاحتياجـات الخاصـة بالتعامـل مـع أوليـاء أمسور التلاميـذ ذوى الاحتياجـات الخاصـة: والتى تسـهم فـى نجـاح المعلم فى القيام بدوره من ناحيـة ؛ وتؤدى إلى تحقيق التوافق والتكيف بين الأسرة والمدرسـة مـن ناحيـة أخـرى • وكانــت النتـائج كمـا وردت فـى الجـدول

جدول رقم (V): التكرارات والنسب المئوية وقيم كاץ (*) والوزن النسبي وترتيب الاحتياجات

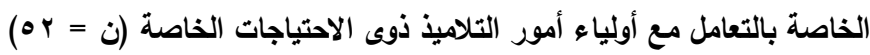

\begin{tabular}{|c|c|c|c|c|c|c|c|c|c|c|}
\hline \multirow{2}{*}{ 高 } & \multirow{2}{*}{$\begin{array}{l}\overline{3} \\
3 \\
\overline{3} \\
\end{array}$} & \multicolumn{2}{|c|}{ is } & \multicolumn{5}{|c|}{ درجة الاحتياج } & العبارة & م \\
\hline & & 哥 & 票 & قليلة جاًا & قليلة & متوسطة & كبيرة & كبيرة جأً & ر إلى معلى فـى & \\
\hline
\end{tabular}

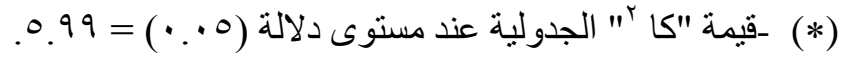

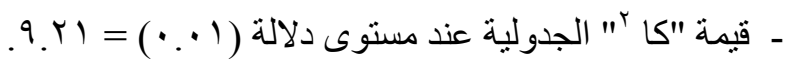




\begin{tabular}{|c|c|c|c|c|c|c|c|c|c|c|c|c|c|c|c|}
\hline & & & & $\therefore$ & $x \Rightarrow$ & $\therefore$ & $\because x \Rightarrow$ & $\therefore$ & $y \Rightarrow$ & $\therefore$ & $\forall \Rightarrow$ & $\%$ & $y \Rightarrow$ & & \\
\hline 1 & s.ro & $\ldots 1$ & $r \leq . \& \uparrow$ & صفر & صفر & 1.9 & 1 & 10.8 & $\wedge$ & $r \wedge .0$ & r. & \&\&.r & $r r$ & أوالولياء أمول مع & ' \\
\hline r & S.r & $\ldots 1$ & $r \ldots .4$ & صفر & صفر & $r .1$ & $r$ & I.r. & 9 & $r ., \gamma$ & iv & r. & $r \xi$ & 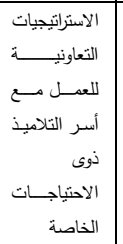 & $r$ \\
\hline 1 & r.q. & $\ldots 1$ & $\{. .19$ & 1.9 & , & 1.9 & 1 & $r r .1$ & ir & $0 \ldots$ & ri & rr. 1 & ir & 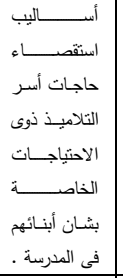 & $r$ \\
\hline$\varepsilon$ & . & $\ldots 1$ & $17 . \mathrm{VV}$ & صفر & صفر & 1.9 & 1 & ro.e & ir & $r \leqslant .$, & is & $r \wedge .0$ & r. & 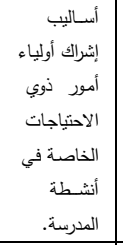 & $\varepsilon$ \\
\hline 。 & $\Leftrightarrow . .+$ & $\ldots 1$ & $r \leqslant .10$ & 1.9 & 1 & 1.9 & 1 & $r, r$ & " & ET.r & rr & $r r . \gamma$ & iv & 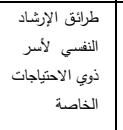 & 0 \\
\hline$r$ & $\{.10$ & $\ldots 1$ & $\leqslant 7 . \leqslant 4$ & 1.9 & 1 & 1.9 & , & 11.0 & i & \{... 1 & ro & r.. & 19 & 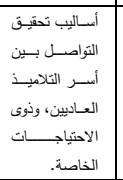 & 1 \\
\hline- & - & - & - & - & $r$ & - & r & - & 09 & - & $i r \lambda$ & - & 110 & جموع التكرارات & \\
\hline- & - & - & - & 1.1 & .0 & r.r & $1 . r$ & $1 \times .9$ & 9.1 & $\Leftrightarrow$ & $r . r$ & rา. 9 & $19 . r$ & لتوسطرات مجموع & \\
\hline
\end{tabular}

يتضح من جدول رقم(V) أن جميع قيم كا` لعبارات المحور الخامس

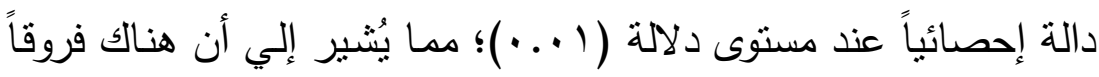
إحصائية بين استجابات أفراد عينة البحث في تحديد درجة الاحتياجات

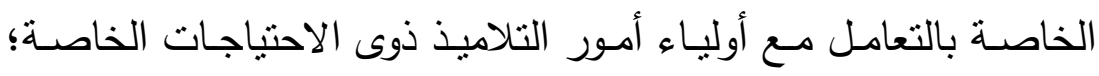

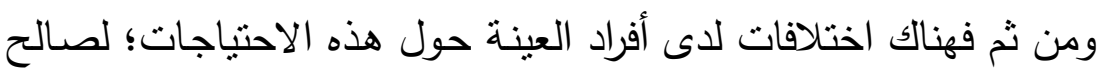

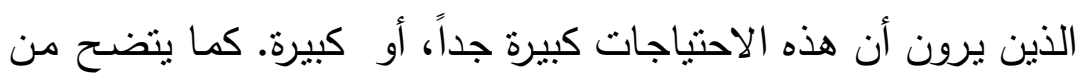


الجدول السابق أن الاحتياجات الخاصة بالتعامل مع أولياء أمور التلاميذ

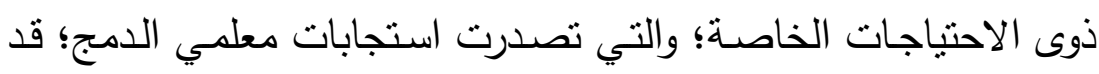

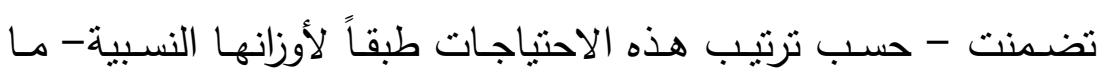
يأتى: ( ) أساليب التواصل مع أولياء أمور ذوي الاحتياجات الخاصة.

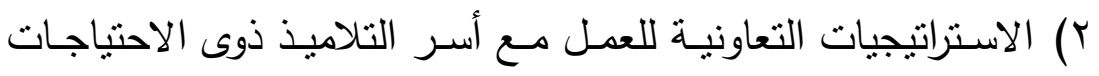
الخاصة. r) أسـاليب إنــراك أوليـاء أمسور ذوي الاحتياجـات الخاصـة في أنشـة المدرسة.

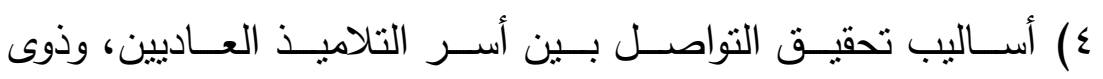
الاحتياجات الخاصة.

0) طرائق الإرشاد النفسي لأسر ذوي الاحتياجات الخاصة.

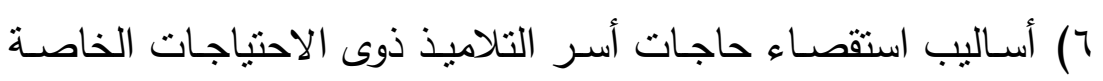
بشان أبنائهم فى المدرسة. ويدل هذا الترتيب للأهداف - كما يدركه أفراد عينة البحث -

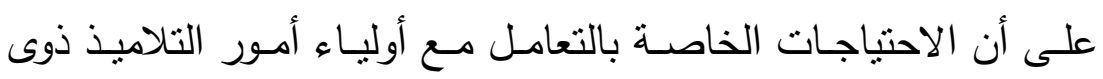

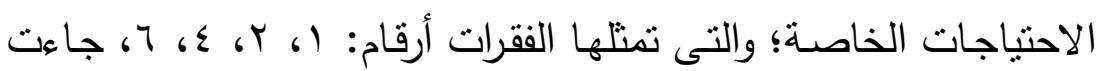

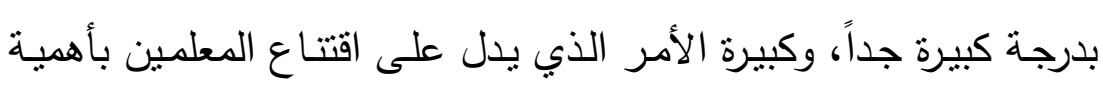

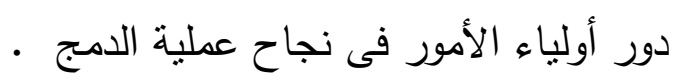

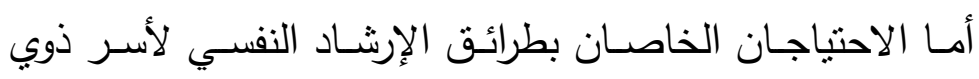

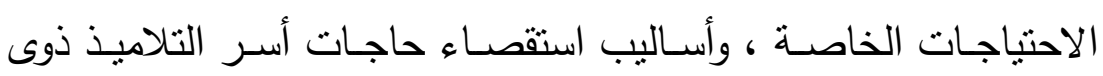

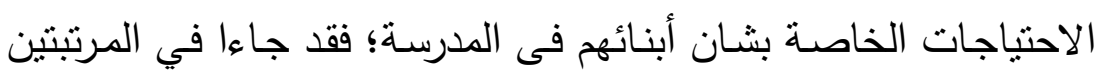

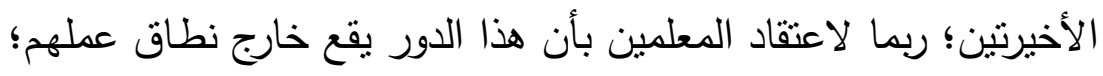
وإنما يتعلق بدور الإخصائيين الاجتماعيين، والنفسيين. 
ويوضح شكل رقم (0): الأعمدة البيانية للنسب المئوية لتكرارات

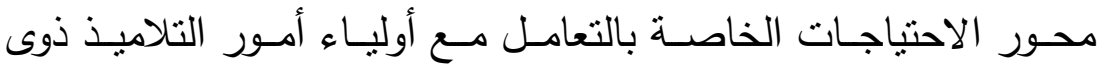
الاحتياجات الخاصة:

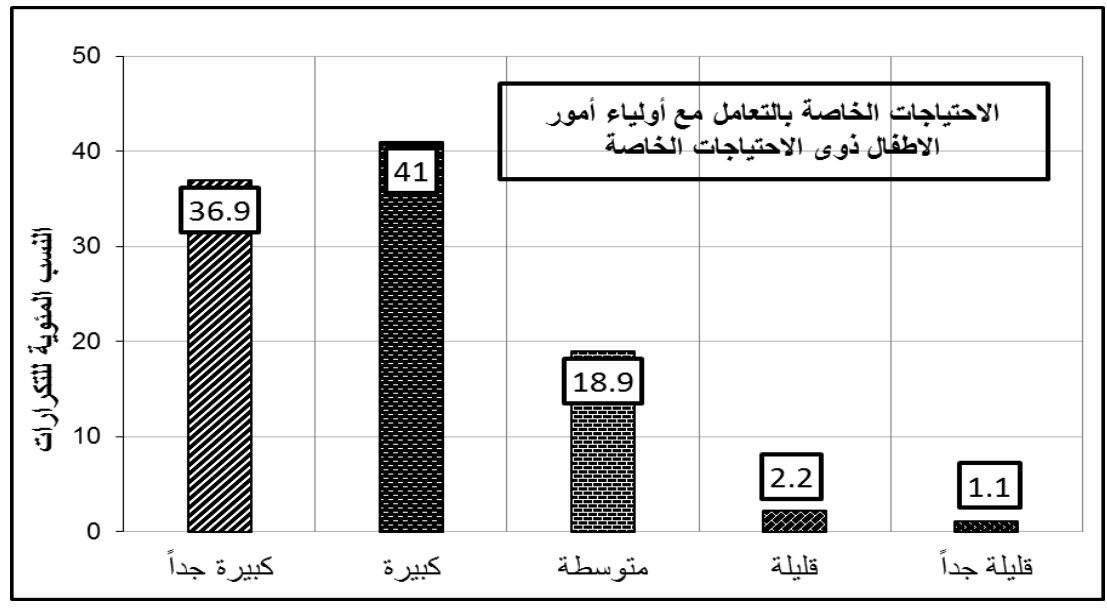

شكل رقم (0): الأعدة البيانية للنسب المئوية لتكرارات محور الاحتياجات الخاصة بالتعامل مع أولياء أمور التلاميذ ذوى الاحتي الاحتياجات الخاصة.

وتتفق هذه النتائج مع دراسـة "على عبد رب النبى محمد حنفى" (00)

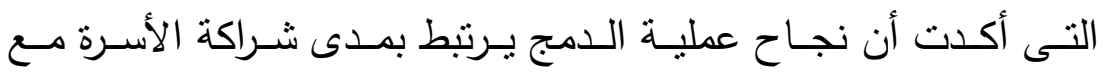

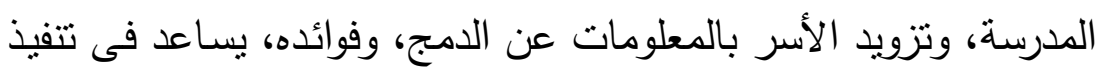

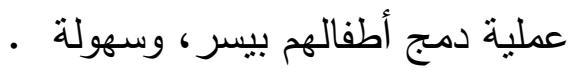

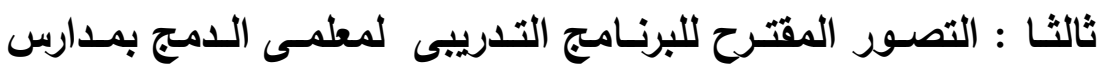
التعليم الابتدائى؛ فى ضوء احتياجاتهم :

بنـاء على تحديد الاحتياجـات التدريبية وفق استجابات عينـة البحث مـن معلمي الـدمج بالمـارس الابتدائيـة بمحافظـة الإسـكندرية؛ وُضـع

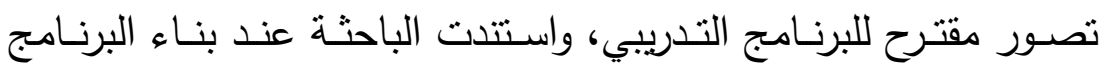

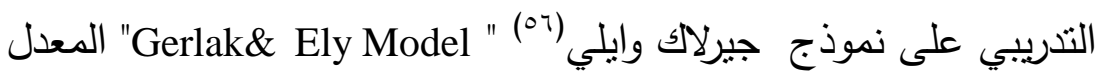
بواسطة الباحثة، والموضح بالثكل رقم (؟) الآتى :

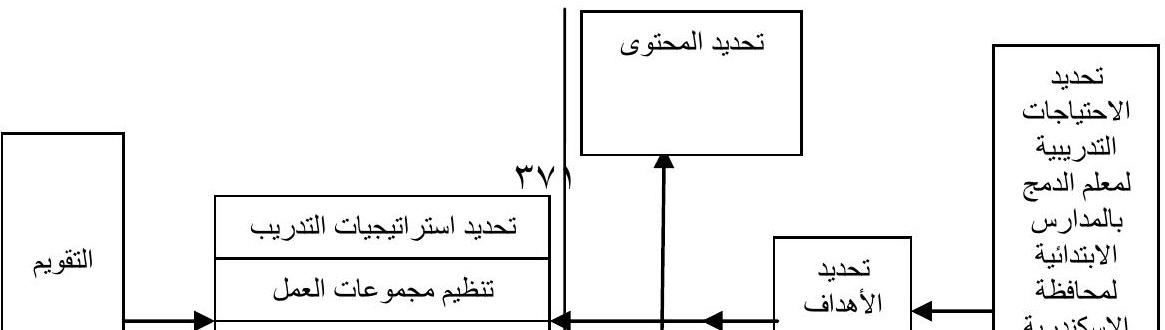


شكل رقم (؟): نموذج جيرلاك وايلي "Gerlak\& Ely Model" للتصميم التعليمي.

ويتضمن البرنامج التدريبى المقترح الخطوات التالية : تحديد فلسفة البرنامج، وأهدافه ائه

يعد التطوير المهنى المستمر عملية ديناميكية، وتعلما مستمراً

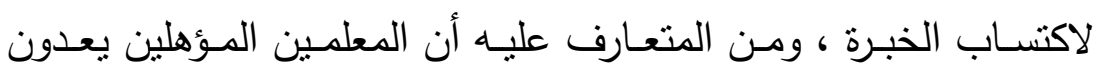

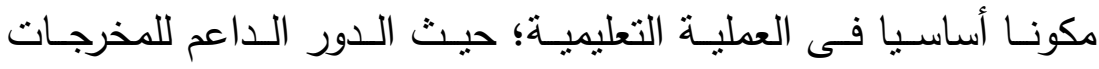

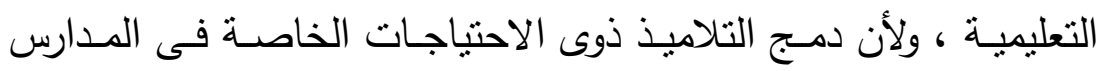

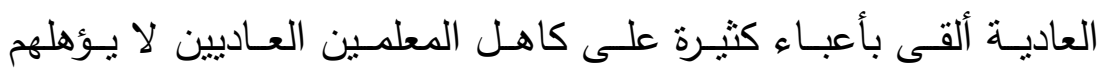

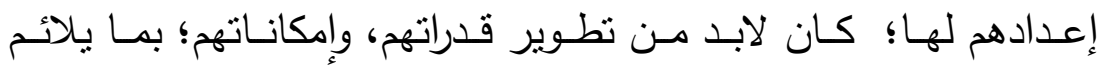
منطلبات عملية الدمج؛ حيث يهدف البرنامج إلى تزويد معلمى الدمج

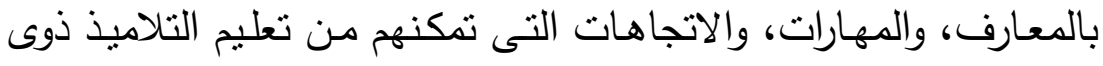

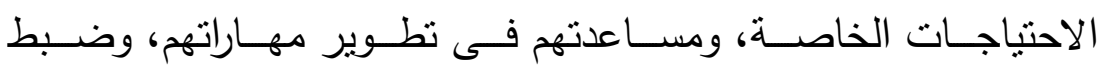
سلوكياتهم، وتبنى أساليب تعليمية تتناسب مع خصائصهم . 
- مدة البرنامج : ه أسابيع فى العام؛ بواقع ץ أيام فى الأسبوع، يتضمن

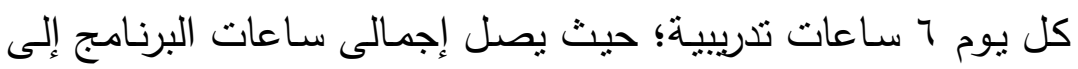
. 9 ساعة تدريبية.

- الفئة المستهدفة :معلمو المدارس الابتدائية العاملون بصفوف الدمج -

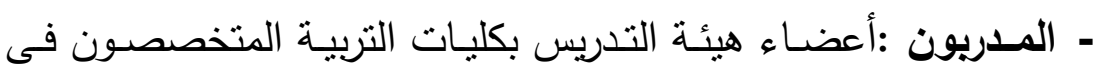
التربية الخاصة، الباحثون والمستشـارون، والموجهون فى مجال التربية الخاصة . الخدة

- أماكن عقد الدورات التريبية : قاعات التدريب فى ( كلية التربية المدارس - الأكاديمية المهنية للمعلمين ) - طرائق التدريب، وأساليبه المستخدمة : العصف الذهني - مجموعات

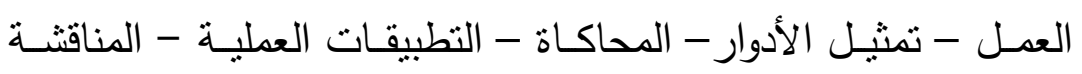

$$
\text { - المواد التدريبية - العروض التقديمية. }
$$

دليل المتدرب : ويبين أهداف كل نشاط وما ينبغي على المتدرب عمله؛ من خلال أوراق العمل التي نتمل مجموعة من الأسئلة،

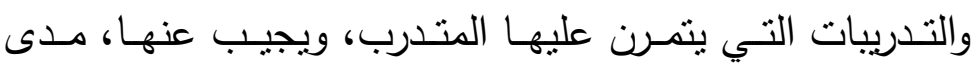
استيعابه ما تمت مناقتتنه . • مادة مرجعية :للتوسع في شرح الموضوعات التدريبية المطروحة

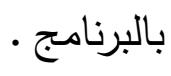
- الأدوات المستخدمة : ورق قابلاب- أقلام ماركر - لاصق - كروت ملونة - أوراق عمل - أوراق إرشادية - عرض تقديمي .

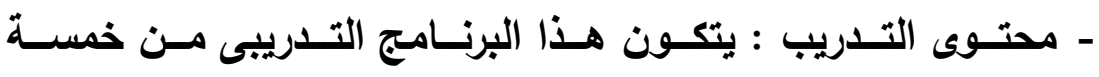

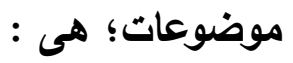
1- الموضوع الأول : معارف عام عن الدمج التربوى 
ץ- الموضـوع الثانى : مهارات تـدريس تتعلـق بتخطبط الدروس، وتتفيذها للتلاميذ العاديين، وذوى الاحتياجات الخاصة .

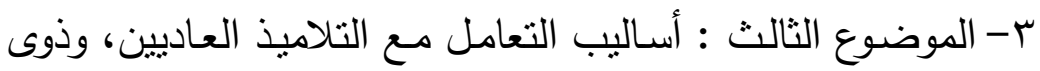
الاحتياجات الخاصة ، وإدارة الصف. ع- الموضوع الرابع : استراتيجيات التقويم •

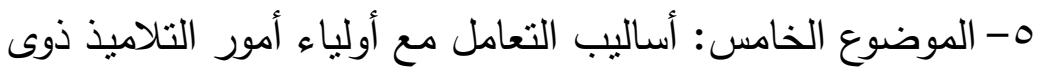

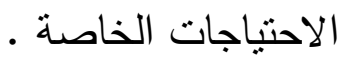
- عدد المتدريين: تتضمن القاعة ( 17 ) متدرباً من معلمي الدمج؛ بحيث تتضمن كل قاعـة (Y) من كن كل إدارة تعليميـة من إدارات

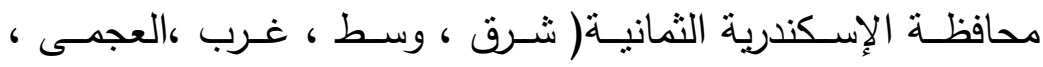
العامرية ، برج العرب ، الجمرك ، المنتزة ). - أسس البرنامج التدريبي، ومرتكزاته ـ التركيز على ورش العمل؛ وليس المحاضرات النظرية فقط . - تقسيم المتدربين إلى مجموعات عمل تعاونية صغيرة كل مجموعة

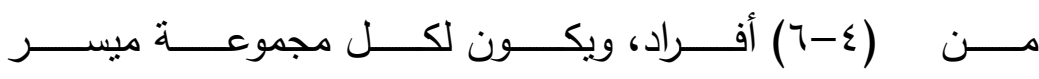

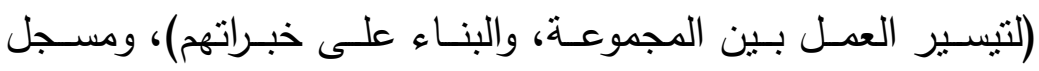

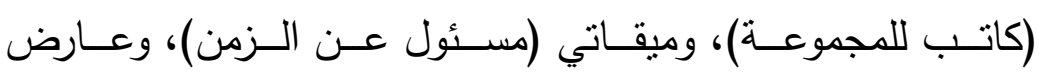

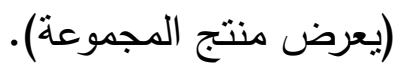
- استخدام استراتيجيات تدريب منتوعة؛ منها : العصف الذهني المناقثة - العمل الفردي - العمل الثنائي - العمل في مجموعات تعاونية. • تقويم مبئي: (اختبار قبلي) لمعلومات المتدربين، وخبراتهم

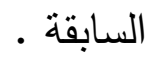


• تقويم في أثناء البرنامج ( التقويم البنائي)؛ ويتضمن: إنتاج

المتدربين في ورش العمل (فردي - جماعي) - مشـاركة

المتدربين مـع بعضهم -الحوار ، والمناقتنات في أثناء تتفيذ

الجلسات - عرض المجموعات، وتقويمها - الملاحظة المنظمة لأداء الأدوار - عمل سجل؛ لمتابعة المتدرب فى أثناء البرنامج،

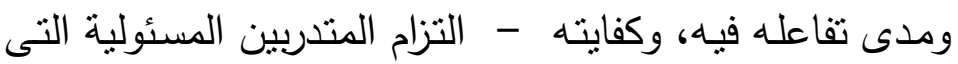
حُدََّتْْ في بداية البرنامج (تقويم في نهاية اليوم التدريبي).

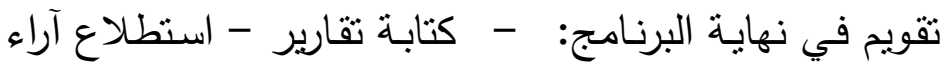
المتدربين في البرنامج - اختبار (بعدي)؛ لتقييم المتدربين،

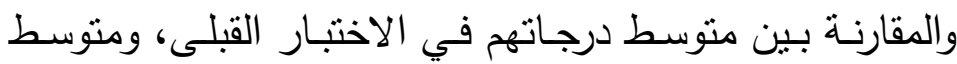
درجاتهم في الاختبار البعدى. - محتوي البرنامج التدريبي المقترح تعرض الباحثة محتوي البرنامج التدريبي المقترح في إطار

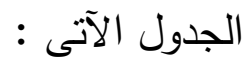


تصور مقترح لبرنامج تدريبي لمعلمي الامج فى المدرسة الابتدائية فى ضوء احتباجاتهم د.هيام عبد الرحيم أحمد 
المشكلات التـي يمكن أن تواجـه البرنـامج التـديبي المقترح، وسبل :

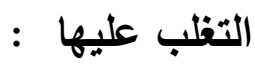

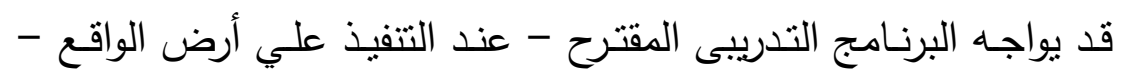
بعض العقبات، يمكن توضيح أهمها وسبل التغلب عليها؛ فيما يلي :

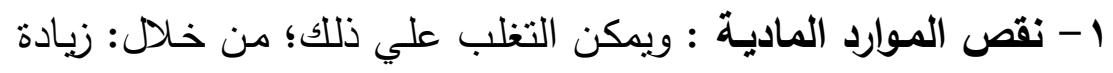

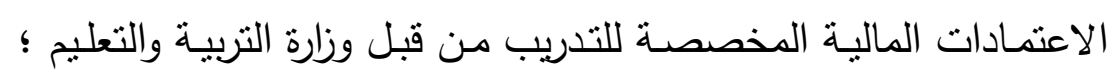
والتعليم العالى ، توفير مصادر للتمويل مثل الاستعانة بموارد الصناديق 
الخاصـة فـى الجامعـات، مشـاركة منظمـات المجتمع المدنى فى توفير بعض مستلزمات التدريب.

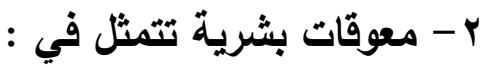

أ- قلة خبرة المدربين القائمين بالتدريب : ويمكن التغلب على ذلك فيه

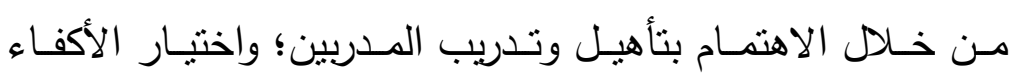
والتدقيق في مراجعة السير الذاتية لاختيار العناصر المناسبة.

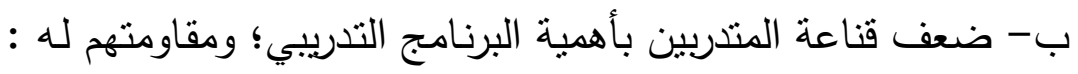
ويمكن التغلب على ذلك من خلال: نشر الوعي بين المشـاركين

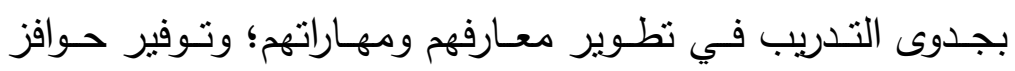
مادية، ومعنوية للمشاركين في البرنامج التدريبي.

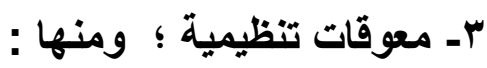

أ- عدم مناسبة مواعيد التذريب للمتدربين ويمكن التغلب على ذللك من خلال طرح بدائل أمام المتدربين لاختيار الموعد الملائم.

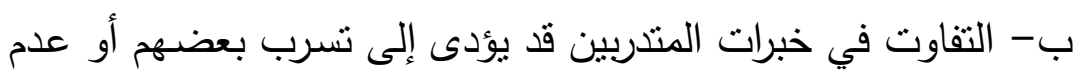

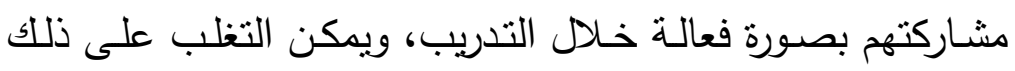
بمراعاة التجانس بينهم من خـلال تقسيم المتدربين فى مجموعات فئهن

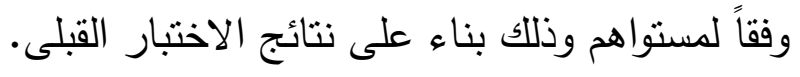

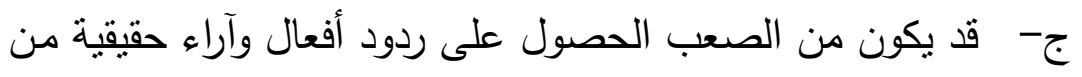

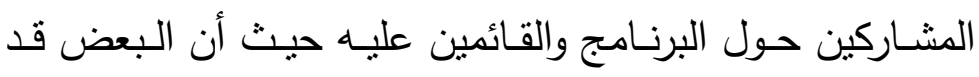
يشـعر بـالحرج مـن إبداء الرأي الصـريح في البرنـامج والقائمين عليه، ويمكن التغلب على ذلك من خـلاه استخدام استمارات

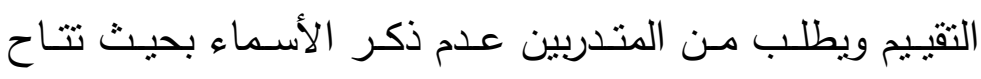
الفرصة أمامهم للتعبير عن آرائهم بحرية. 


\section{مراجع وهوامش الدراسة}

ا ـ أميرة إبراهيم القرشي ، "متطلبـات الدمج الثـامل للتناميذ المعـاقين

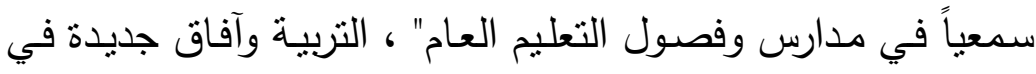

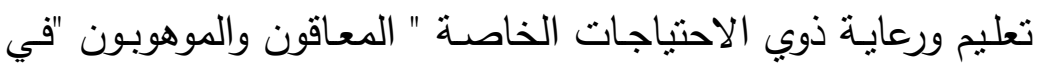

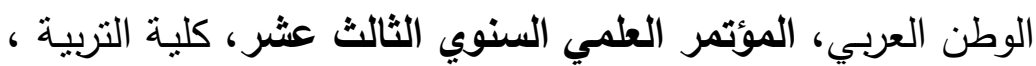

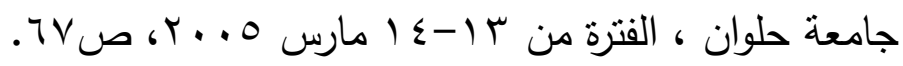


r. سـهير الصباح ، سـيلة خميس ، وآخرون ، الصعوبات التي تواجه

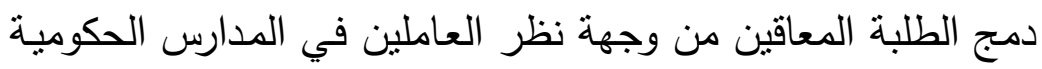
الأساسية في فلسطين ( السلطة الوطنيـة الفلسطنية : وزارة التربية

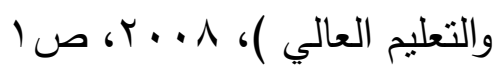

http://site.iugaza.edu.ps/aelholy/files/.pdf

3. Lilian Mariga,Lineo Phachaka, Integrating Children with Special Needs into Regular Primary Schools in Lesotho,(Ministry of Education Maseru: Lesotho,1993),P.14.

4. UNESCO: World Conference on Special Needs Education: Access and Quality, Salamanca, Spain, 7- 10 June, 1994, P.9.

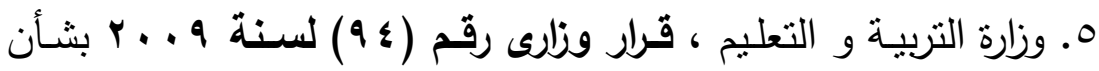
قبول التلامبذ ذوى الإعاقة الطفيفة بمدارس التعليم العام.

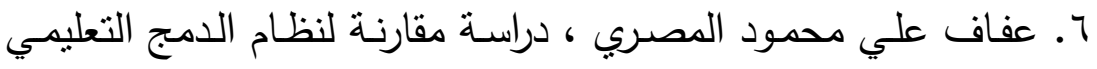

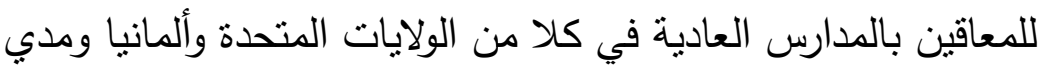

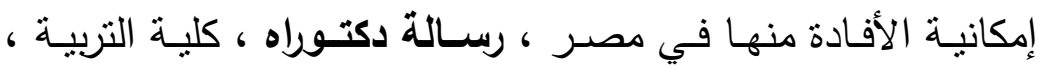

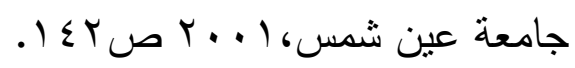

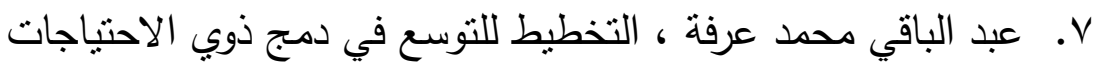

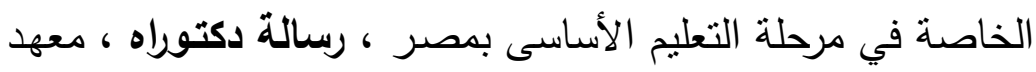

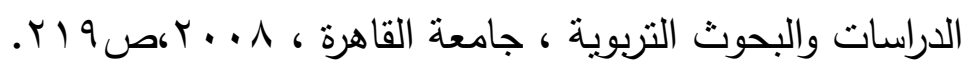

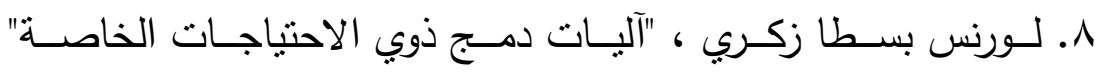

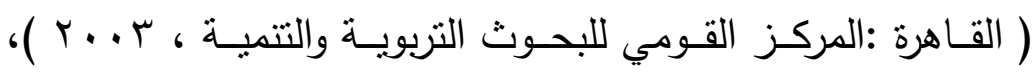

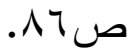
9 ـ هدي محمد الجابر ، فاعلية برنامج تدريبي لتتمية الكفايات الثخصية والمهنية لدي المعلمين في تغيير اتجاهاتهم نحو دمج الأطفال ذوي 
الاحتباجـات الخاصـة، رسـالة دكتوراه ، كليـة التربية، جامعـة عين

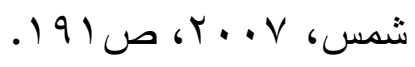

• . . سالى كوكس ماييرى و برندا بلسون لازاروس ،تعليم التلاميذ ذوى الته الاحتباجات الخاصـة في فصول القرن الحادى والعشرين ، ترجمة

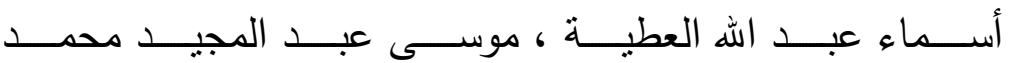

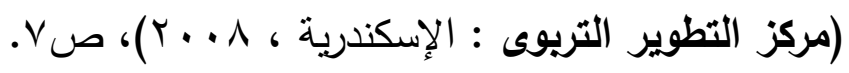

ا ا ـ عبد المجيد بن سليمان الجربوع، دور تحديد الاحتباجات التدريبية

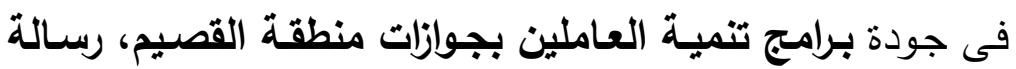

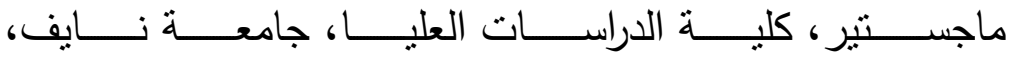

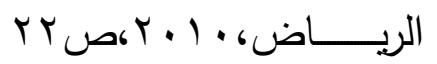

www.nauss.edu.sa/Ar/DigitalLibrary/.../Document s/m_as_38_2010.pdf

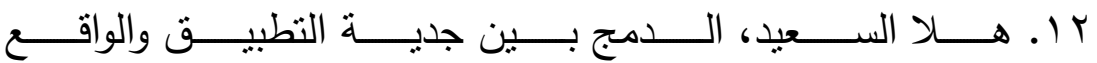

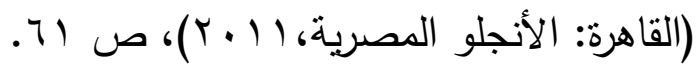

با ـ فـاروق السـعيد جبريـل و مصـطفي السـعيد جبريـل، ســيكولوجية

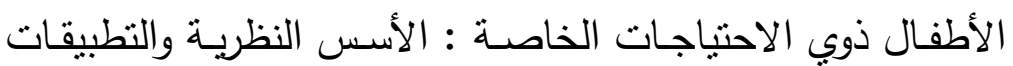

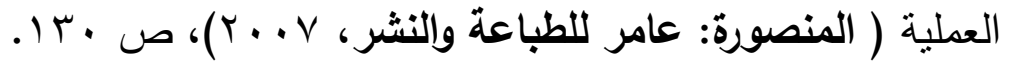
ـ ا ـ خلف محمد البحيرى و هدى مصطفى محمد ، "دمج غير العاديين فى التعليم - إثنكالية المنهج والمعلم "، معا ...على طريق الدمج الثـامل لذوى الاحتياجـات الخاصـة فى الوطن العربى ، المـؤتمر القـومى الثـامن ، اتحـاد هيئات رعايـة الفئات الخاصـة والمعوقين

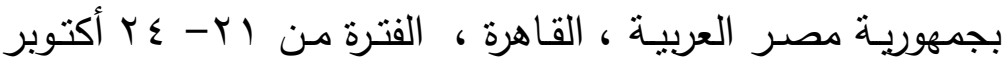

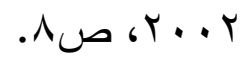


1 ـ ـديان برادلى وآخرون، الدمج الشـامل لذوي الاحتياجـات الخاصـة

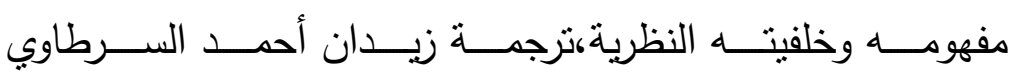

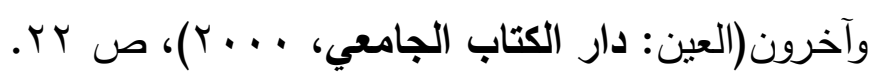

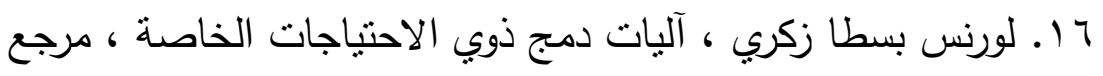

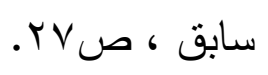

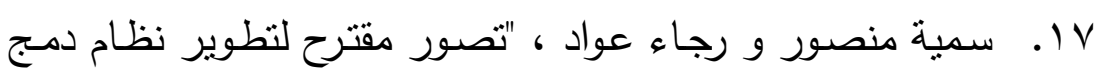

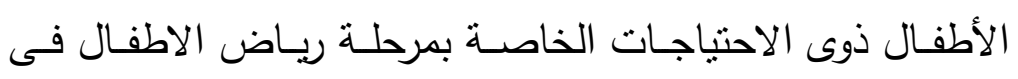

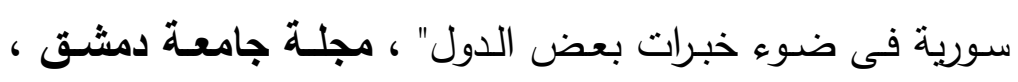

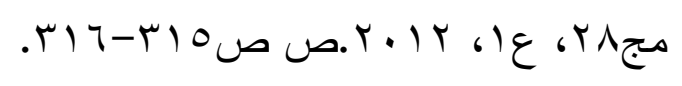

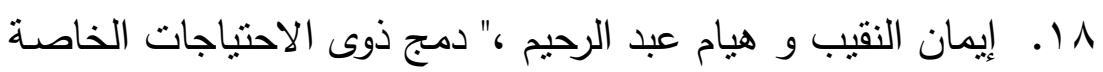

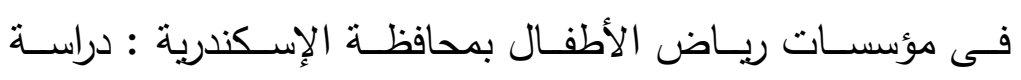

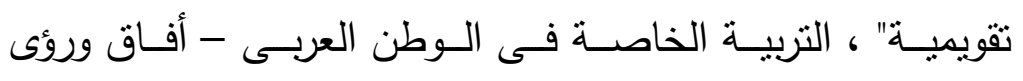

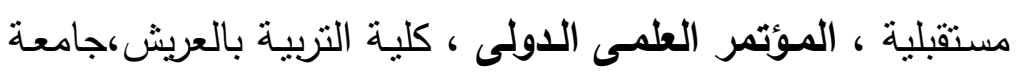

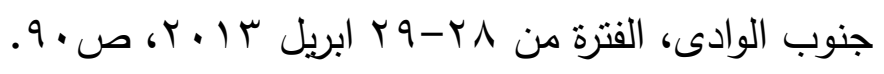

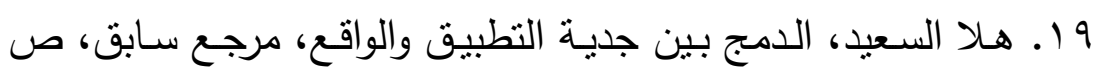

$$
\text { ص ص } 9799
$$

- بطرس حافظ بطرس ، سيكولوجية الدمج فى الطفولـة المبكرة

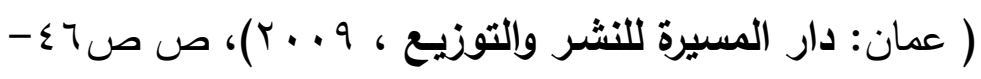

- - سهير محمد سلامة شـاش، التربية الخاصـة للمعاقين عقلياً بين

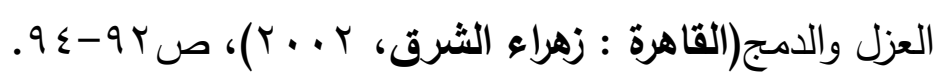

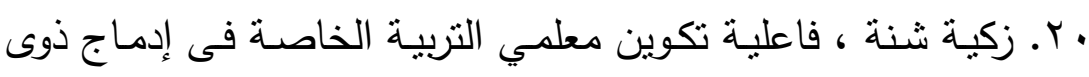

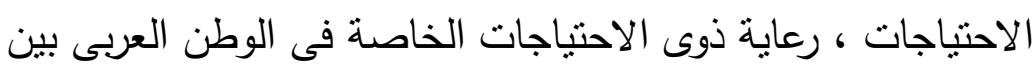

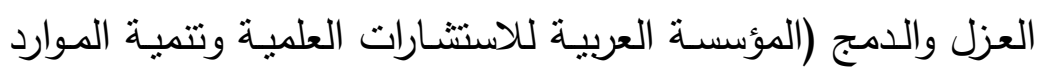

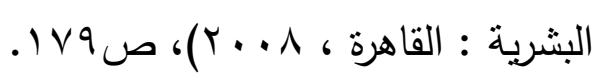


ا r . خلف محمد البحيرى و هدى مصطفى محمد ، "دمج غير العاديين

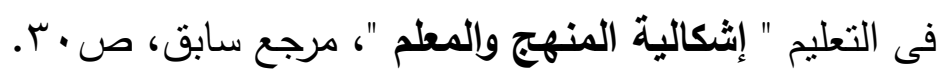

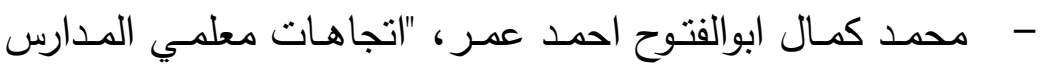

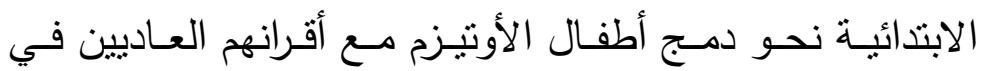
المدارس العامة :دارسة سيكولوجية في ضوء بعض المتغيرات" ،

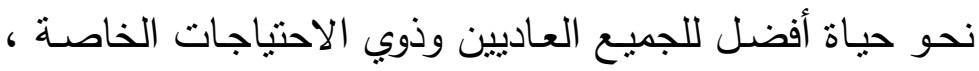

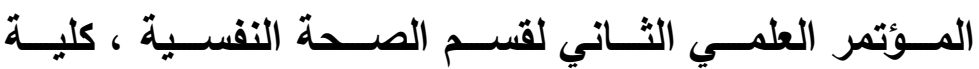

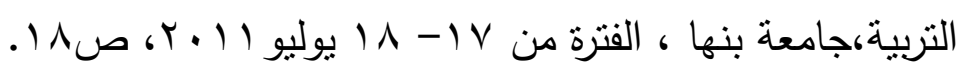
r r. أميرة إبـراهيم القرشـى، متطلبـات الدمج الثـامل للتناميذ المعـاقين

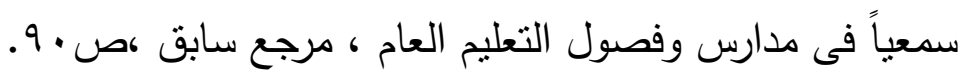

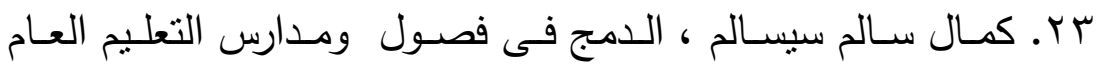

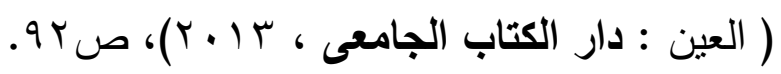

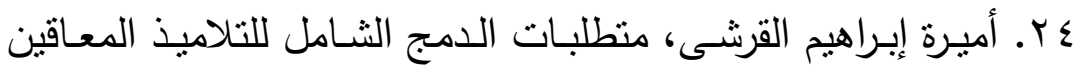

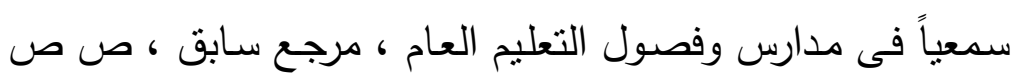
$.9 r-9 r$

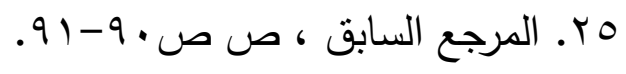

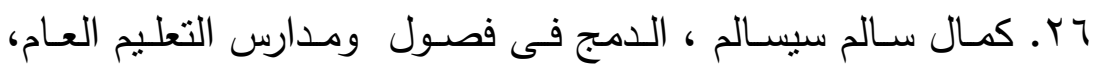

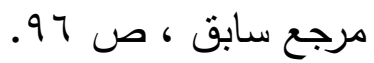

27. Reiber ,Christophe and McLaughlin, T. F., Classroom Interventions: Methods To improve academic performance and classroom behavior for students with attention- deficit/hyperactivity disorder.International Journal of Special

Education.Vol. 19, No.1.,pp1-13.

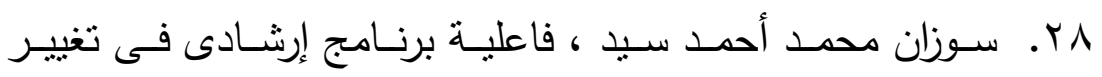

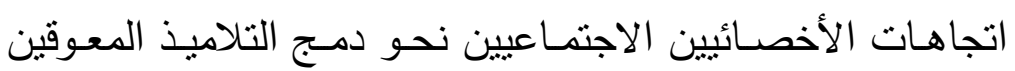


عقليأ مع أقرانهم العاديين ، رسالة ماجستير ، كلية التربية- جامعة

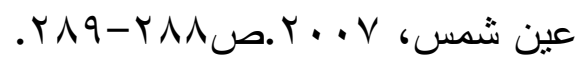

9ץ. كمال سالم سيسالم ، الدمج فى فصول ومداري التعليم العام، مرجع

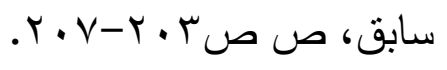

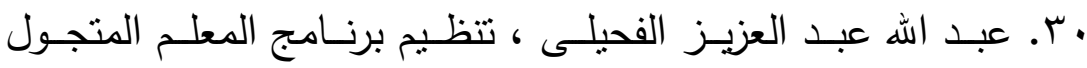

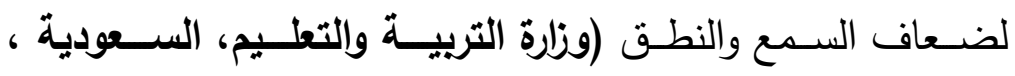

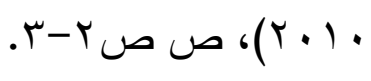

اس فــاروق السـعيد جبريـلـ و مصــفى السـعيد جبريـل، سـيكولوجية

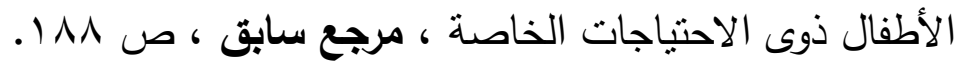

32. Lehtomaki, Elina, Inclusion and Deafness:

Families as essential stakeholders, University of Jyvaskyla,1999, http://www.eenet.org.uk/

- فتحى مصطفى الزيات ، دمج ذوى الاحتياجات الخاصة ، مرجع سابق، ص IVT

سז.سـالى كوكس مـاييرى و برندا بلسـون لازاروس ،تعليم التلاميذ ذوى

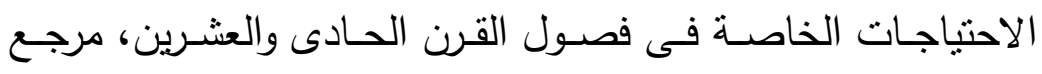

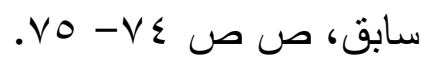

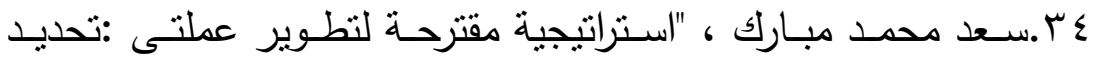

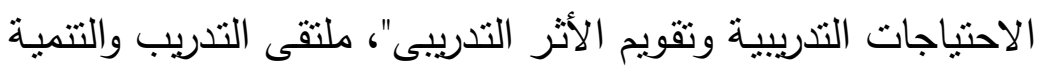

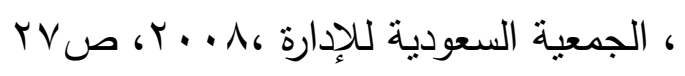

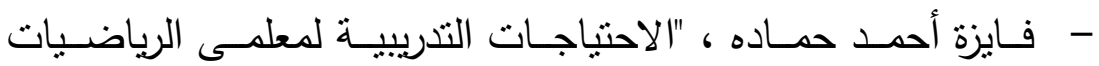

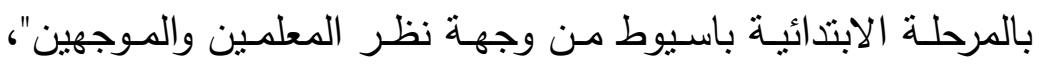

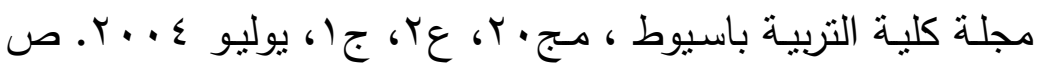


- محد محمد عبد الهادى بدوى، "برنامج تدريبى مقترح قائم على نظم

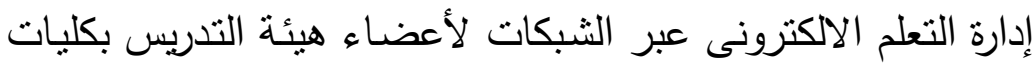

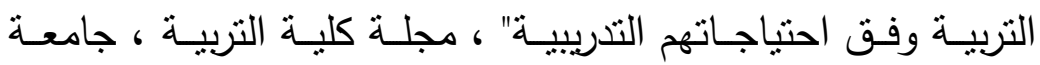

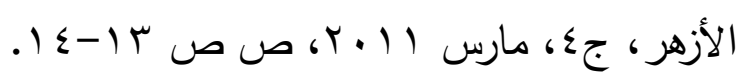

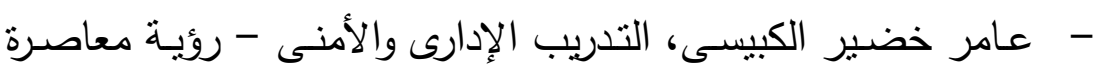

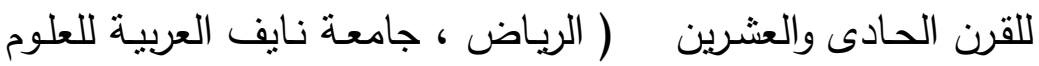

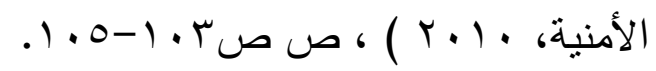

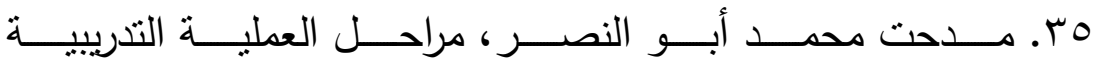
(تخطبط وتتفيذ وتقويم البرامج التدريبية )(القاهرة : المجموعة العربية

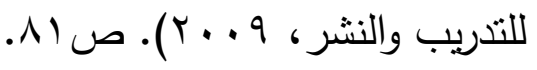

جس. عامر خضير الكبيسى، التدريب الإدارى والأمنى - رؤية معاصرة

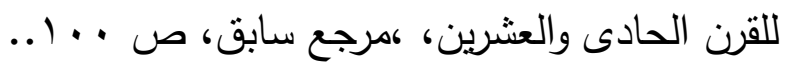
rV

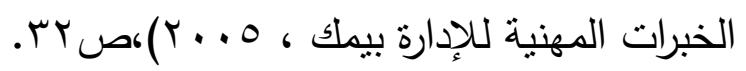
^r . سلطان بن محمد بن فالح الجابرى ، الاحتياجات التدريبية لمديرى

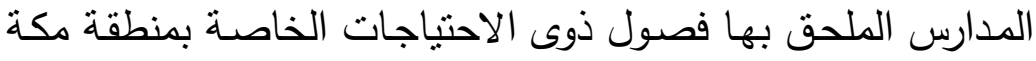
المكرمـة مـن وجهـة نظـر مـديرى ومعلمى تلـك المـارس ، رسـالة

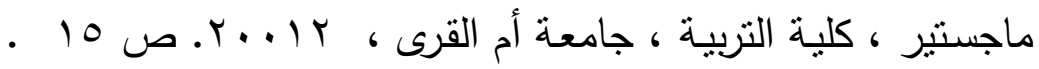
http://libback.uqu.edu.sa/hipres/ABS/ind12778.pdf

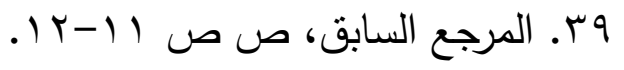

•ـ. عصـام عطـا اله حسين الخليفـات ، تحديـد الاحتياجـات التدريبيـة لضمان فاعلية البرامج التدربيية (عمان: دار صفاء للنشر والتوزيع،

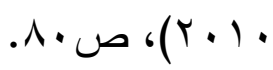




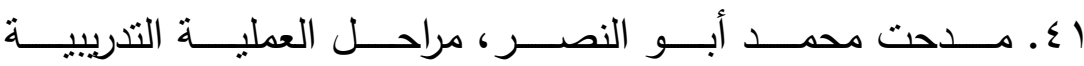

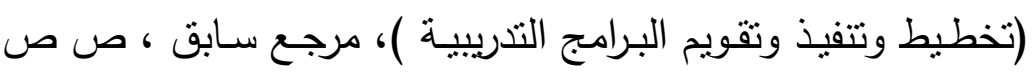
$. \wedge 7-\wedge 0$

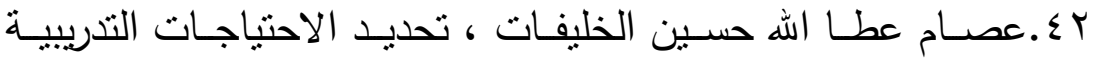

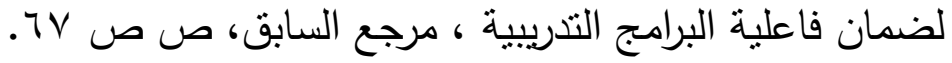

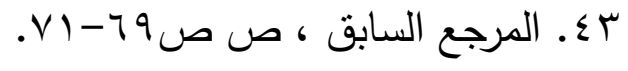

؟ ـ. عبد الرحمن توفيق ، التدريب بالوسـائط المتعددة، مرجع سـابق ،

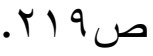

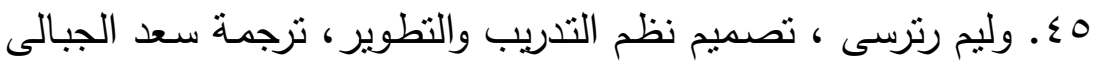

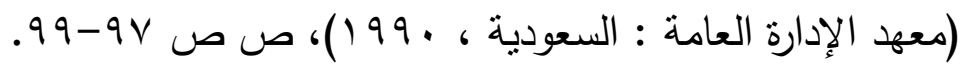

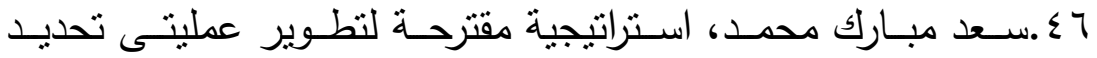

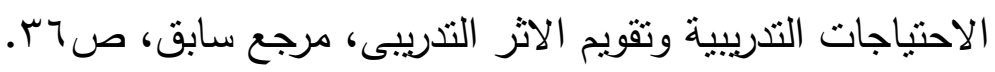
\& V أحمـــ الرفـاعي غنـيم، ونصـر محمـود صـبري،التحليل الإحصـائي

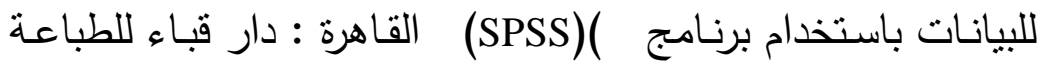

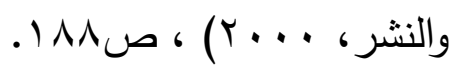

^§ ـسوزان محمد أحمد سيد ، فاعلية برنامج إرشادى فى تغيير اتجاهات

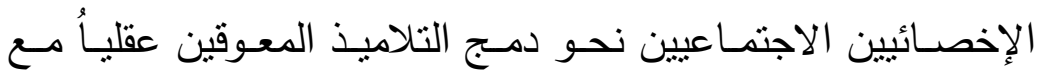
أقرانهم العاديين ، مرجع سابق. 9 § أميـرة إبـراهيم القرشـى، منطلبـات الـدمج الثــامل للتلاميذ المعـاقين سمعياً فى مدارس وفصول التعليم العام ، مرجع سابق. 


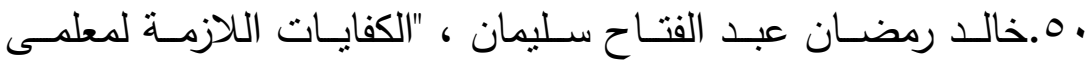

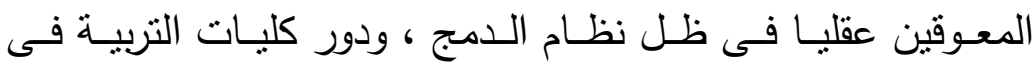

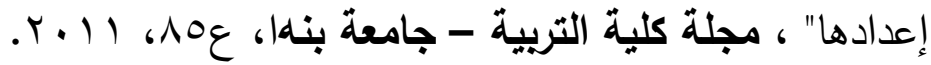
10باسم محمد أبو قمر و عبد الهادى حمدان مصـالحة ، "اتجاهـات

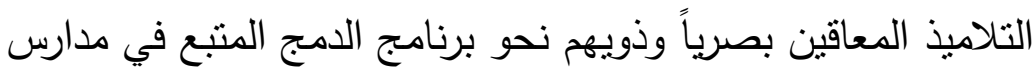

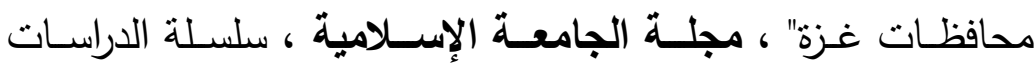

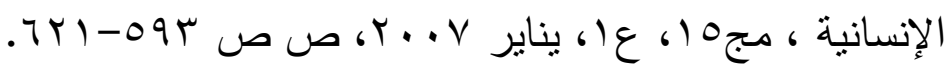
52 .راند مصطفى الديب ، "المشكلات التى تواجه عملية دمج الأطفال

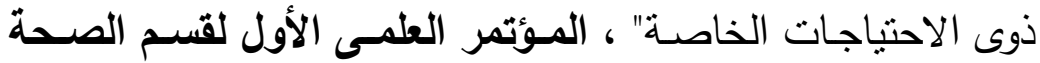

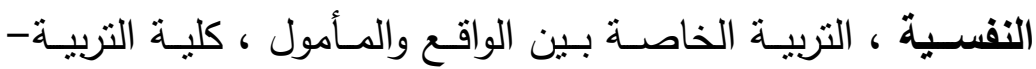

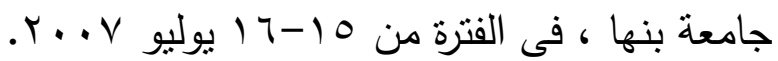

53.أمانى محمود عبد الله ،معوقات الدمج التى تواجه معلمات رياض التلاميذ عند تدريس التلاميذ غير العاديين من وجهة نظر .المشرفات

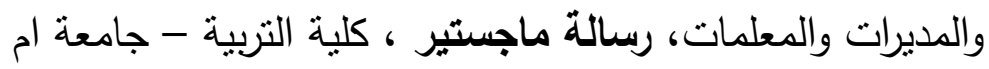

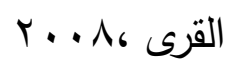
http://libback.uqu.edu.sa/hipres/FUTXT/5622.pdf 54 .خالـــ رمضـان عبـد الفتـاح سـليمان ، الكفايـات اللازمـة لمعلمىى

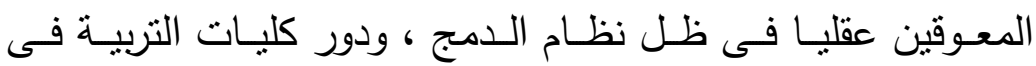

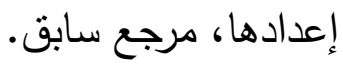

55 على عبد رب النبى محمد حنفى، "منطلبات دمج الطلاب الصم فى

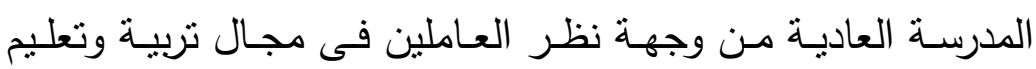


الصـم والسـامعين - دراسـة مبيدانيـة بمدينـة الريـاض"،التـدوة العلميـة

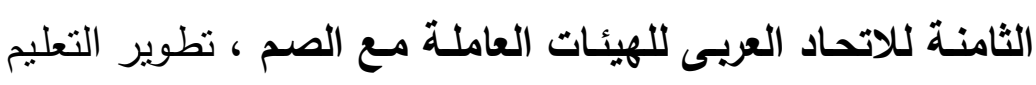

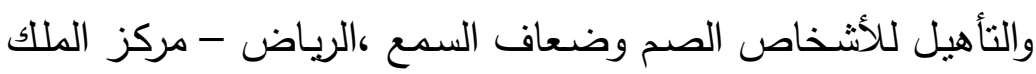

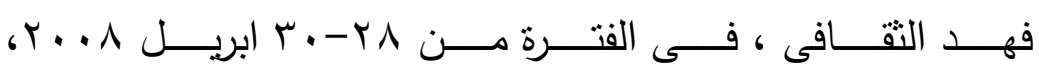
ص ص ص ص

56-Gerlach, Vernon S. \& Donald P. Ely ‘Teaching \& Media: A Systematic Approach '2th edition ، (Englewood Cliffs, New Jersey: PrenticeHall,Inc.,1980). www.ticidio.mex.t1/.../Modelo\%20Gerlach\%20y\%2 OEly 